Portland State University

PDXScholar

\title{
A Demographic Study of Two Alcoholic Populations in a State Hospital
}

James John Schelot

Portland State University

Follow this and additional works at: https://pdxscholar.library.pdx.edu/open_access_etds

Part of the Social Work Commons

Let us know how access to this document benefits you.

\section{Recommended Citation}

Schelot, James John, "A Demographic Study of Two Alcoholic Populations in a State Hospital" (1977). Dissertations and Theses. Paper 2577.

https://doi.org/10.15760/etd.2572

This Thesis is brought to you for free and open access. It has been accepted for inclusion in Dissertations and Theses by an authorized administrator of PDXScholar. Please contact us if we can make this document more accessible: pdxscholar@pdx.edu. 
AN ABSTRACT OF THE THESIS OF James John Schelot for the Master of Social Work presented May 20, 1977.

Title: A Demographic Study of Two Alcoholic Populations in a State Hospital.

APPROVED BY MEMBERS OF THE THESIS COMMITTEE:
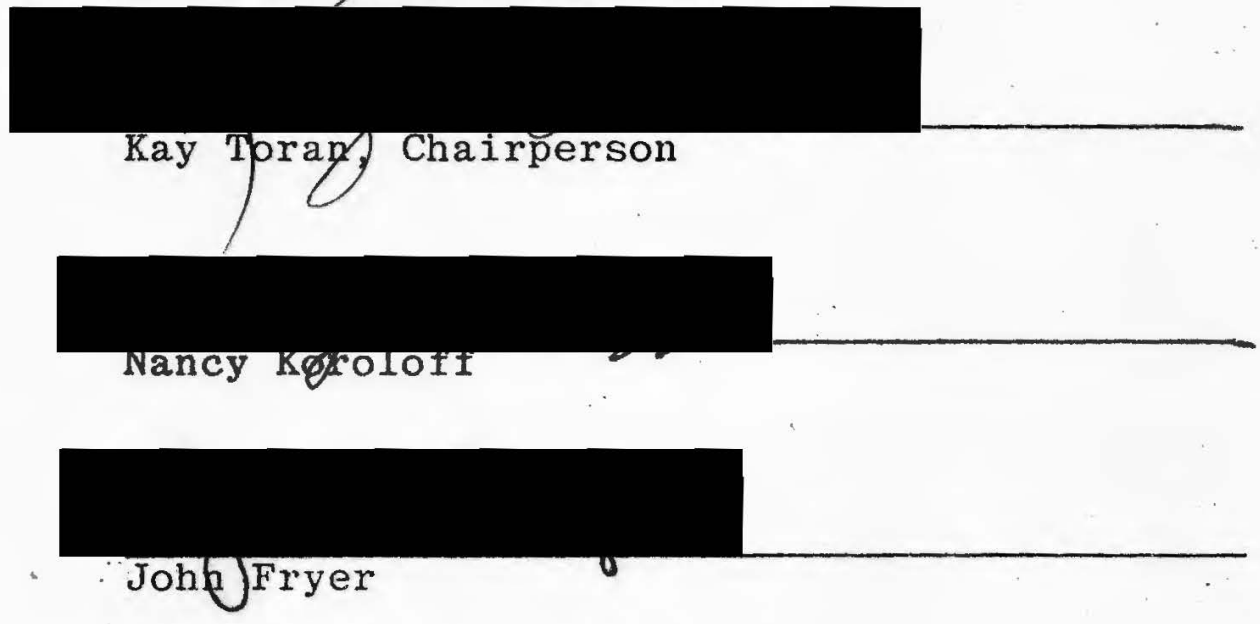

Twenty-five alcoholic patients in the Alcohol Treatment Program at Dammasch State Hospital near Wilsonville, Oregon, and twenty-five alcoholic patients in the same hospital who.were not participating in the progran were given a questionnaire designed to collect demographic data on both groups. The demographic characteristics were to be gathered in order to assess the possible need of diversified treatment programs for alcoholic patients at Damasch State Hospital and in the Portland community. Demographic data involved the social background, 
the alcohol background, and the medical/psychological

history of the patients.

The results seemed to suggest that the two groups of patients were more similar than dissimilar regarding demographic characteristics. However, differences were noted between the two groups on the patients' preference for the treatment of alcoholism. This might imply a need for a more diversified choice of treatment. 


\title{
A DEMOGRAPHIC STUDY OF TWO ALCOHOLIC
}

\section{- POPULATIONS IN A STATE hOSPITAL}

\author{
by \\ JAMES JOHN SCHELOT
}

\begin{abstract}
A thesis submitted in partial fulfillment of the requirements for the degree of
\end{abstract}

MASTER OF SOCIAL WORK

Portland State University June, 1977 
TO THE OFFICE OF GRADUATE STUDIES AND RESEARCH:

The members of the Committee approve the thesis of James John Schelot presented May 20, 1977.

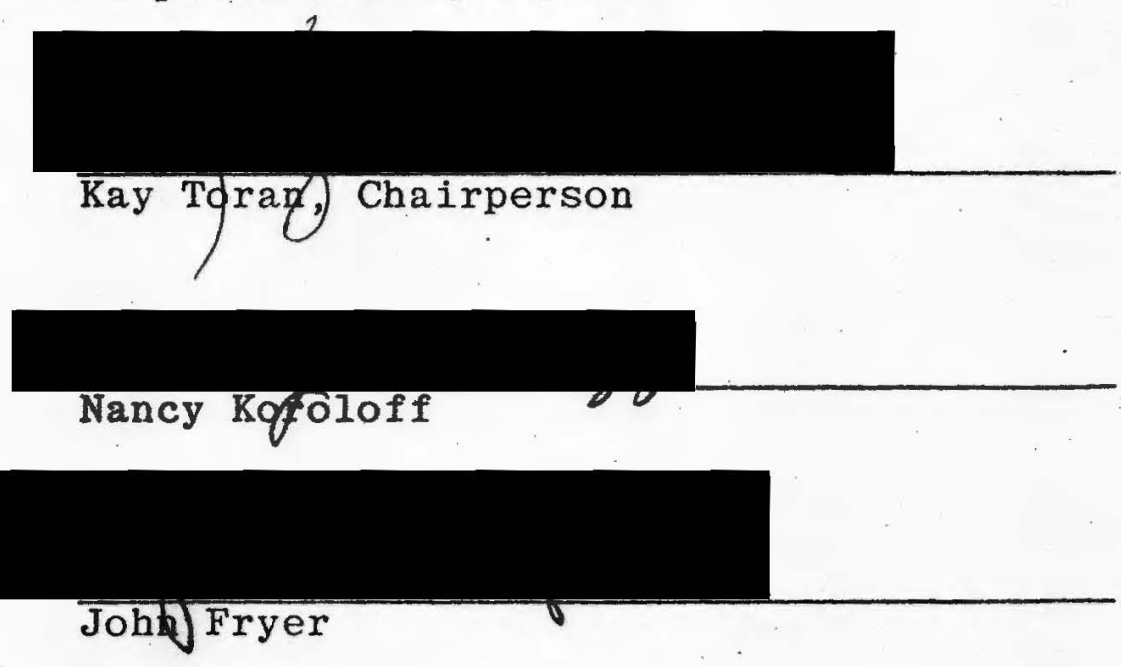

APPROVED :

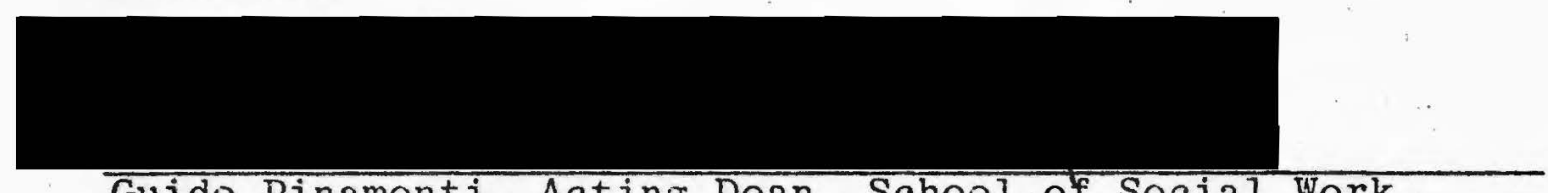

Guido Pinamonti, Acting Dean, School of Social Work

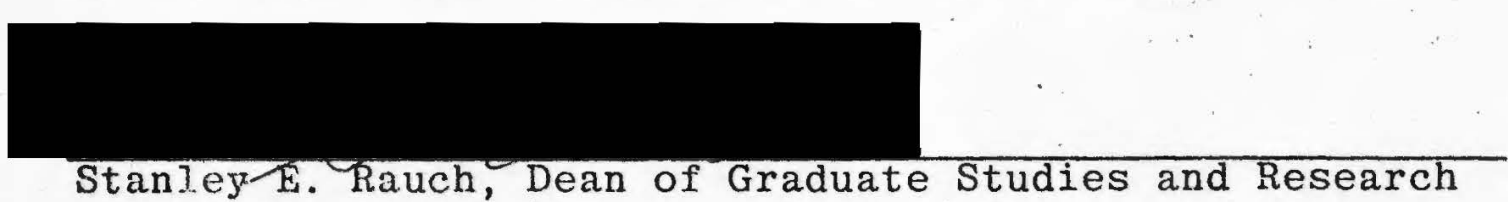




\section{ACKNOWLEDGMENTS}

With much gratitude, I would like to thank my Committee for their technical expertise and my friends and family for their emotional support.

Kay Toran, Nancy Koroloff, and John Fryer provided exceptional guidance as committee members. Scott Eckelman, Don Robertson, James Sidwell, my parents, and other good friends helped to maintain my interest and my equilibrium. Without the help of these people, this project could never have been completed. 
TABLE OF CONTENTS

PAGE

ACKNOWLEDGEMENTS . . . . . . . . . . . . . . ili

LIST OF TABLES $\ldots \ldots \ldots \ldots \ldots \ldots \ldots \ldots$ vi

CHAPTER

I INTRODUCTION. . . . . . . . . . . . . . 1

II REVIEW OF THE LITERATURE. . . . . . . . . 6

Definition of Alcoholism . . . . . . 6

Explanations of Alcoholism . . . . . . 10

Approaches to Treatment. .......... 19

Demographic Studies of Alcohol Treatment

Programs . . . . . . . . . . . . 26

III METHODOLOGY . . . . . . . . . . . . 31

IV RESULTS . . . . . . . . . . . . . 39

Social Background. . . . . . . . . . 39

Alchohol Background. . . . . . . . . 55

Medical/Psychological History. . . . . . 78

$\mathrm{V}$ SUMMARY AND CONCLUSION. . . . . . . . . . 87

Summary of Social Background . . . . . . 87

Summary of Alcohol Background. . . . . . 88

Summary of Medical/Psychological History . . 89

Conclusion . . . . . . . . . . . 90

SELECTED BIBLIOGRAPHY . . . . . . . . . . . . . 93

APPENDIX A . . . . . . . . . . . . . . . . 98

APPENDIX B . . . . . . . . . . . . . . . . . 100 



\section{LIST OF TABLES}

TABLE

PAGE

I Patients' Ages . . . . . . . . . . 40

II Order of Sibling Birth . . . . . . . . . . 42

III Highest Level of Education of Patients' Fathers. 44

IV Highest Level of Education of Patients' Mothers. 45

V Highest Level of Education of Patients . . . . 46

VI Main Source of Income. . . . . . . . . . 47

VII Current Marital Status . . . . . . . . . . 49

VIII Hobbies or Recreational Organizations. . . . . 51

IX Living Situation a Month Before Entering the Hospital. . . . . . . . . . . . 53

$\mathrm{X}$ Time Spent in a Penitentiary . . . . . . . . 54

XI Patients Who Believe They Have a Drinking Problem . . . ... . . . . . . . 56

XII Reaction To First Drinking Experience. . . . . 58 XIII Style of Drinking. . . . . . . . . . . . 59

XIV Alcohol Substitutes Consumed . . . . . . . . 61

XV Patients who have the Ability to Stop Drinking . 63

XVI Drinking Pattern Before Entering the Hospital. . 64

XVII Patients who were Intoxicated. when Admitted into the Hospital . . . . . . . . . . . 66

XVIII Patients who feel Guilty about Their Drinking. . 70 XIX Patients who Express Anger or Start Fights when

Drinking. . . . . . . . . . . . . . 71

XX Professional Help Sought by Families . . . . . 73 
XXI Patients Experiencing. Family Disruption due to Drinking . . . . . . . . . . . .

XXII Patients Who want to Stop Drinking Completely . 76

XXIII Change in Living Situation. . . . . . . . . 77

XXIV Previous Hospitalizations for Alcohol Abuse . . 79

XXV Level of Health . . . . . . . . . . . 81

XXVI Major Medical or Psychiatric Treatment. . . . 82

XXVII Use of Hard Drugs . . . . . . . . . . 84

XXVIII Preference for an Alcohol Treatment Program

Outside of a State Hospital. . . . . . 86

$\operatorname{XXIX}$ Ethnic Group. . . . . . . . . . . . 116

XXX Persons with Whom Patients Resided-for Most of

Their Early Life. . . . . . . . . . 117

XXXI Number of Brothers . . . . . . . . . . 118

XXXII Number of Sisters . . . . . . . . . . 119

XXXIII Occupation of Father . . . . . . . . . 120

XXXIV Occupation of Mother . . . . . . . . 121

XXXV Patients who were Employed at the Time of

Admission to the Hospital. . . . . . . . 122

XXXVI Patients' Types of Employment . . . . . . . 123

XXXVII Number of Jobs Held in the Past Year. . . . . 124

XXXVIII Annual Gross Income . . . . . . . . . . . 125

XXXIX Number of Times that Patients have been Married .126

XL Patients who have Children. . . . . . . . 127

XLI Religious Preference. . . . . . . . . 128 
XLII Church Attendance. . . . . . . . . . . 129

XLIII List of Hobbies and Recreational Organizations. 130 XLIV Length of Time Spent in Oregon. . . . . . . 131

XLV Number of Moves in the Past Year. . . . . . . . 132

XLVI Patients who were in a Detoxification Center

before Entering the Hospital . . . . . 133

XLVII Number of Close Friends in the Community. . . . 134

XLVIII Number of Arrests for Intoxicated Related Charges

in the Past Year . . . . . . . . . . 135

LXIX Number of Arrests for Anything Else (other than

Intoxication Related Charges) in the Past Year.136

L Current Charges . . . . . . . . . . 137

LI Age When Patients had Their First Drink . . . 138

LII Persons with Whom Patients had Their First

Drinking Experience. . . . . . . . . . 139

LIII Places Where Patients Usually Drank Before

Entering the Hospital. . . . . . . . . 140

LIV Amount of Wine Consumed Daily . . . . . . . 141

LV Amount of Beer Consumed Daily. . . . . . . . 142

LVI Amount of Hard Liquor Consumed Daily. . . . . . 143

LVII Loss of Employment due to Drinking . . . . . . 144

LVIII Drinking for the Purpose of Relaxation. . . . . 145

IIX Drinking in Order to be Sociable. . . . . . . 146

LX Drinking in Order to forget Unpleasant Thoughts. 147

LXI Drinking in Order to Feel Less Depressed and 
LXII Drinking to Relieve Angry Feelings. . . . . . 149

LXIII Drinking in Order to Relate Feelings and Thoughts to the Opposite Sex. . . . . . . . . . 150

IXIV Drinking in Order to Change Mood. . . . . . . . 151

LXV Drinking in Order to Shut Out the World . . . 152

LXVI Suicide Attempts While Drinking . . . . . . . 153

LXVII Hardships on Family Due to Drinking . . . . . . 154

LXVIII History of Drinking Problems in Patients'

Families. . . . . . . . . . . . . 155

LXIX Change in Associates . . . . . . . . . . 156

LXX Group Therapy . . . . . . . . . . . . . . 157

LXXI Alcoholics Anonymous . . . . . . . . . . 158

LXXII Individual Therapy . . . . . . . . . . . . . . 159

LXXIII Education on Effects of Alcohol. . . . . . . 160

LXXIV Community Treatment of Alcohol Abuse . . . . . 161

LXXV Level of Health Compared with a Year Ago . . . 162 LXXVI Use of Antabuse . . . . . . . . . . . . . . . . . . . . . . . . . 


\section{CHAPTER I}

\section{INTRODUCTION}

In the spring of 1976, the director of the Alcohol

Treatment Program at Dammasch State Hospital near Wilsonville, Oregon, was approached to determine if there was an interest in researching alcoholism as a thesis topic. The director suggested the development of a demographic study which would examine two populations diagnosed as alcoholics at Dammasch State Hospital for the purpose of identifying similarities and differences. One population of alcoholics in the hospital participated in a specific alcohol treatment program, while the other alcoholic population did not become involved with this specialized unit. The director was interested in knowing demographic similarities and differences in the two populations in order to have information which might be of value for developing specialized programs to meet the needs of the alcoholic patients not currently involved in a program. Multnomah County was also interested in this information so that adequate planning could be achieved for the development of alcohol programs within the county.

The above proposal seemed feasible and it satisfied the interest of the researcher. A decision was made to carry out the proposal as there was familiarity with the 
alcohol treatment program and Dammasch State Hospital and the project appeared to be of a useful nature.

In order to understand the development of the two populations in this study, an examination of Dammasch State Hospital, where treatment occurred, is necessary. This hospital is part of Oregon's Mental Health Division. The state has two other hospitals which serve counties other than those served by Dammasch State Hospital. Eastern Oregon State Hospital in Pendleton is used by populations of Central and Eastern Oregon. Oregon State Hospital in Salem serves counties in Western Oregon below the metropolitan area of Portland. Dammasch serves Clatsop, Columbia, and Tillamook Counties of Northwestern Oregon, and also Clackamas, Washington, and Multnomah Counties.

Dammasch began operation in 1961 and has a capacity of over 400 patients. At the time of the study, the hospital was divided into five wards designated for women and seven wards for men. Patients are admitted into the hospital in one of two ways: 1) court committed or 2) voluntarily admitted. For patients of the latter category, admission is granted by an attending physician who makes a determination that a person requesting admission needs an inpatient facility and is diagnosed for neurotic or psychotic symptoms as described by the Diagnostic and Statistical Manual of Mental Disorders by the American Psychiatric Association. 
All physicians rotate the responsibility of interviewing people requesting admission. If a patient is accepted, he or she is assigned to the psychiatric ward of the physician who has been designated for new admissions. At the time of this study, alcoholics and drug problem patients made up approximately 40 percent of admissions and the other 60 percent involved psychiatric problems outside of drug and/or alcohol abuse.

In looking at patients diagnosed with some kind of alcohol problem, admission procedures differed between men and women at the time of this study. Women were admitted directly to a ward specifically for female alcoholics for detoxification and/or treatment. Male alcoholics, however, were admitted on the psychiatric ward of the admitting physician for detoxification rather than being placed immediately on the ward specifically for alcohol treatment of males. If a male was completely detoxified and accepted for alcohol treatment, he would then be transferred to the Alcohol Treatment Program.

The Alcohol Treatment Program began as a federally funded project in 1972 and was given a grant for three years to establish an inpatient treatment program with post-hospital follow-up for patients once discharged. Funds were made available through the State and Multnomah County to keep the program operating after the federal grant had elapsed. 
Staffing for this program included the director, a social worker by training, five follow-up counselors, and a secretary. In addition, the hospital provided two physicians, a social worker, and nursing personnel.

Admission to the Alcohol Treatment Program involved the use of a screening committee where a patient's motivation and needs were evaluated and a determination was made to assess whether the Alcohol Treatment Program could be of service. Patients who were accepted made an agreement to stay for thirty days and were then transferred into the program.

Men who did not meet the above criteria or did not wish to stop drinking, or felt they didn't need to change their behavior in order to stopdrinking returned to the care of the referring physician on the psychiatric ward. Some of the wards offered group therapy, but usually not specifically for alcoholics. Ninety percent of the people requesting admission in the program were accepted at the time of this study.

Participation in the program involved attendance of a variety of group therapies with the intended purpose of expressing feelings. Groups included Alcoholics Anonymous, an Alcohol Orientation Class (lectures on alcohol and alcoholism), Relaxation (techniques in reducing tension), Looking Inside (improving self-awareness), Transactional Analysis (looking at alcoholism through alcoholic games), Women's Group (examining specific problems for 
women), Logotherapy (examining goals and how to achieve them), Recovery, Inc. ( a national organization of former mental hospital patients and/or people with emotional problems who provide self-help techniques). In addition, each patient was provided the opportunity of receiving services in the community by a counselor who would offer individual or group therapy in an outpatient clinic or through home visits.

The populations for this study were derived from participants who were located in general wards at Dammasch. The two groups of patients were asked to take part in this study with the understanding that involvement was on a voluntary basis and that no names would be used in order to maintain confidentiality. One group of patients consisted of hospitalized males and females who had been diagnosed as alcoholics and were admitted into the Alcohol Treatment Program. The other group involved hospitalized males who had been diagnosed as alcoholics but, for a variety of reasons, did not participate in the specialized programs and remained on regular psychiatric wards within the hospital. 


\section{CHAPTER II}

\section{REVIEW OF THE LITERATURE}

In examining the literature on alcoholism there were three subject areas that were of major interest. These included descriptions of alcoholism, treatment approaches to alcoholism, and an exploration of demographic studies on alcoholism. The literature research revealed an overwhelming: number of articles and books on the subject of alcoholism, thus, only these studies of particular relevance to this study have been included. The three subject areas listed above have been explored in the review to follow.

Definition of Alcoholism

Looking firstat definitions of alcoholism, an

all encompassing definition or description of alcoholism does not exist. This may be reflected by a lack of agreement among professionals in the field of alcoholism. Speculation for the reasons for such disagreement may be due to a widely held belief that there are many types of alcoholism and this has led to the use of an eclectic: approach in describing alcoholism as Roebuck and Kessler suggest below:

There is no universally accepted definition of alcoholism, and many scholars contend that the term encompasses a wide range of pathological behavior syndromes associated with alcohol use. In short, it might be appropriate to speak of 'alcoholisms' rather than alcoholism, since there are a number of distinct disorders whose major common characteristic is the pathological seeking for, and reaction to, the effects of alcohol. Specifications in the literature are mixed and 
vary from the disease concep to pure sociological frames of reference. 1

In examining the various definitions in common usage, several deal exclusively with the damage caused to the individual and to society. Of particular importance in this category would be Jellinek's view that alcohol causes damage to the individual or society or both. ${ }^{2}$

The concept of loss of control is used in some definitions of alcoholism. Diethelm feels that a person is an alcoholic if the use of alcohol "interferes with a successful life in the physical, personality, or social spheres, and if he is unable to recognize the deleterious effects of alcohol or is unable to control his alcohol consumption even though he recognizes its negative effects."3

Chafetz and Demone describe alcoholism as a chronic behavioral disorder which is signified by undue preoccupation with alcohol to the detriment of physical and mental health, by a loss of control when drinking has begun, and by a self-destructive attitude in life situations. 4

1Julian B. Roebuck and Raymond G. Kessler, The Etiology of Alcoholism (Springfield, Illinois: Charles C. Thomas, 1972), p. 3 .

${ }^{2}$ E. Morton Jellinek, The Disease Concept of Alcoholism (New Haven, Conn.: College and University Press, 1960), p. 7 .

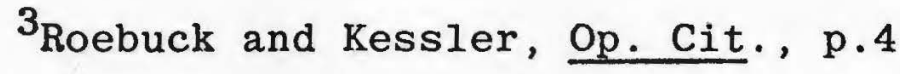

${ }^{4}$ Morris E. Chafetz and Harold Demone, Alcoholism and Society (New York: Oxford University Press, 1962), p. 38. 
From a sociological view, Clinard sees alcoholism in the context of the individual's culture. Alcoholics would be viewed as deviating from the norm in terms of amount of alcohol intake and by the unconventional times and places selected for drinking. 5

Although considerable variety in definitions of alcoholism exist, certain aspects of alcoholism are common to most theoretical formulations. These would include the following:

1. Self destruction of the individual abuser.

2. Interference with physical, mental, and/or social functioning or adjustment.

3. Exceeding the norms, dietary, or social customs of the society in terms of quantity, frequency and time and place of alcohol consumption.

4. The inability to stop drinking. ${ }^{6}$

The World Health Organization has developed a formula which has incorporated several. of the concepts described above:

Alcoholics are those excessive drinkers whose dependence upon alcohol has attained such a degree that it shows a noticeable mental disturbance or an interference with their bodily and mental health, their smooth social and economic functioning; or who show the signs of such development.7

$5_{\text {Roebuck and Kessler, Op. Cit., p.4 }}$

${ }^{6}$ John K. Fryer, Attendance at Out-Patient Clinics as a Function of Risk Taking for Alcoholics (Portland, Oregon: Portland State University, 1975), p. 16

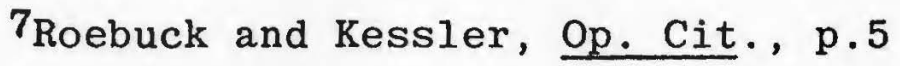


This organization separates alcoholics into two groups:

Excessive drinkers and alcohol addicts. ${ }^{8}$ The difference between the two groups relates to loss of control of drinking by the alcohol addict but not for the excessive drinker.

The Diagnostic and Statistical Manual of Mental Disorders by the American Psychiatric Association categorizes alcoholism into three types. These categories are the criteria used by physicians at Dammasch State Hospital in order to admit patients for alcoholism. The first diagnosis, episodic excessive drinking (303.0), is where alcoholism (defined aspatients whose alcohol intake is great enough to damage their physical health, or their personal or social functioning) is present and the individual becomes intoxicated as much as four times a year, with intoxication being considered "a state in which the individual's coordination or speech is definitely impaired or his behavior is clearly altered". 9

The second diagnosis, habitual excessive drinking (303.1), involves individuals considered to be alcoholics and have been intoxicated more than twelve times a year or have been under the influence of alcohol more than once a $8_{\text {Ibid., p. } 5 .}$

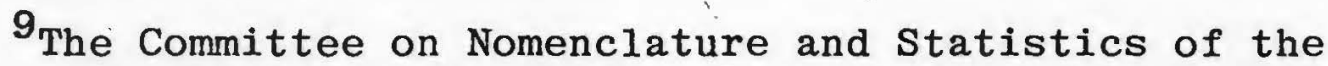
American Psychiatric Association, Diagnostic and Statistical Manual of Mental Disorders (Washington, D.C.: American Psychiatric Association, 1968), p. 45. 
week even if they have not been intoxicated. ${ }^{10}$. The last diagnosis, alcohol addiction $(303.2)$ is used for patients where "there is direct or strong presumptive evidence that the patient is dependent on alcohol."11 Evidence is considered to be the appearance of withdrawal symptoms, an inablility of the individual to go one day without drinking, and an assumption that alcohol addiction has occurred when heavy drinking has continued for three months or more.

\section{Explanations of Alcoholism}

There are three major theoretical approaches used currently to explain the etiology and nature of alcoholism The first is called the constitutional approach. This approach considers the cause of alcoholism to be mainly physiological and "that some physiological or structural defect produces a predisposition which yields addiction when the individual is introduced to alcohol."12

The second major approach used to explain alcoholism. is the sociological approach which is mainly concerned with explaining and defining rates of alcoholism for different groups. 13

The third major theoretical approach postulates that an individual's psychological mechanisms and personality are

$$
\begin{aligned}
& { }^{10} \text { Ibid., p. } 45 . \\
& { }^{11} \text { Ibid., p. } 45 . \\
& { }^{12} \text { Fryer, Op. Cit., p. } 16 . \\
& { }^{13} \text { Ibid., p. } 20 .
\end{aligned}
$$


the major causes of alcoholism. ${ }^{14}$

Although all three approaches for the explanation of alcoholism are evident at Dammasch State Hospital, the third approach, psychological mechanisms, seems to be particularly important in treatment methods at Dammasch State Hospital and the Alcohol Treatment Program appears to emphasize this approach in its explanation and treatment for alcoholism. More specifically, the use of psychoanalytic and transactional analytic approaches (both part of the psychological mechanisms approach) seem to be particularly evident in treatment through individual counseling and group treatment. As this seems to be the case, both approaches as explanations for alcoholism are explored below in detail. Looking first at the psychoanalytic approach, explanations of behavior involves the interpsychic, or historical review on alcoholism. It has generally considered alcoholism, in terms of addiction, as dependence on an alcohol substance which provides pleasure on the one hand and relief from psychic pain (such as anxiety or depression) on the other hand. Blum suggests that:

Such dependence is conceived of as resulting from developmental failure. Addiction protects the individual from the graver consequences of this failure: suicide, psychosis, asocial or criminal behavior. It represents a compromise solution.15

${ }^{14}$ Ibid., p. 19.

15Eva Maria Blum, "Psychoanalytic Views of Alcoholism: a Review", Quarterly Journal of Studies on Alcohol, XXVII (1966), p. 263. 
Developmental failure, as discussed above, has been attributed by psychoanalysts to be the result of fixation at various stages of growth and/or regression to previously outgrown stages. The severity of such fixation and/or regression determines the severity of the alcohol problem:

The earlier the developmental stage at which an individual has been arrested, the more infantile his behavior and personality, the more severe his drinking problem if he becomes an alcoholic and the poorer his prognosis. Individuals who have achieved emotional maturity but have regressed under the impact of unfavorable life circumstances may be only temporarily affected. The latter are more likely to return to their previous level of social and personal functioning, whether they have been helped by psychoanalytic or other means. 16

The psychoanalytic approach generally describes three areas of development as being responsible for the alcoholic's apparent inablility to grow. These areas involve excessive dependency, relations to parents, and fixation at developmental stages.

Looking first at excessive dependency, studies of alcoholics by Knight, Wall, and Higgins suggest that "thwarting, spoiling, or rapid alternation between both extremes prevents the infant from progressing toward interdependency."17 With this type of background, the psychoanalytic approach would infer that the alcoholic continues to use methods for obtaining pleasure which would be ap-.. propriate to his or her early helplessness where nurturance was demanded but not returned.

$$
\begin{aligned}
& 16 \text { Ibid., P. } 264 . \\
& { }^{17} \text { Ibid., p. } 265 .
\end{aligned}
$$


The problem of mismanagement of early dependency, then, would be considered an important element in the occurrence of alcoholism.

The second area of development considered to be partially responsible for alcoholism involves the alcoholic's relationship with his/her parents. It is suggested here that the alcoholic models himself upon impressions of what his parents are like, impressions which are based on actual pathological characteristics and perhaps false or inaccurate recollections. Blum elaborates on the above:

Case histories of inebriates are replete with notes about alcoholic fathers... and mothers. Patients are said to identify with these inadequate models. Further, the activities surrounding pathological drinking and in particular its consequences may come to be invested with private meaning for the alcoholic, symbolizing the dependence, ambivalence, love or hate toward parents and parent substitutes, which cannot be expressed in any other way. 18

One additional comment in regard to the alcoholic's relationship with his parents deals with parents who have been overly punitive. Such punitive actions, according to psychoanalytic views, may be repeated by the alcoholic toward himself as an adult in the form of self-inflicted punishment. This punishment might include hangovers, loss of jobs and loss of friends and spouse.

The third area of development considered to be also involved with alcoholism is fixation at developmental stages. ${ }^{18}$ Ibid., P. 265. 
Examining the oral stage first, many authors believe that this is the stage where there is a halt in emotional growth for alcoholics. It is their contention that damage during the nursing period will result in characteristics of alcoholics which seem much like that of an infant. Such characteristics would include "their pleasure in the bottle..., intolerance of frustration, pain, and anxiety, irresponsibility and emotional liability,... and (dependence) economically and emotionally."19 A poor prognosis is generally given for alcoholics which are considered to be fixated at this stage.

Another developmental state, the anal stage, is a point where many alcoholics are believed to be fixated. This stage involves asserting selfhood and learning sphincter control. Characteristics include aggressiveness, cruelty, rebellion-all of which are attributed to the alcoholic who has stopped growth at this stage. Homosexual tendencies are believed to be typical when fixation occurs here.

Alcoholics are given a more favorable prognosis at this stage as egofunctioning has developed. It is felt that such an alcoholic "is capable of transforming destructive tendencies into potentially useful ones." 20

The phallic-oedipal stage is one other stage where

$$
\begin{aligned}
& { }^{19} \text { Ibid., p. } 266 . \\
& 20 \text { Ibid., p. } 267 .
\end{aligned}
$$


fixation or regression may occur for alcoholics. It is believed that such people have not been able to come to terms with sexual feeling toward their mother. Such alcoholics have progressed to the point of choosing heterosexual love, but "reexperience difficulties with authority figures similar to those which beset them during the days when jealousy and impotence colored their feeling toward their father."21 Characteristics of people fixated at this stage would include tendencies toward anxiety, repressed anger, rebelliousness, fear of sexual inadequacy, and low selfesteem.

Levy, looking from a psychodynamic perspective, has outlined eight functions of alcohol which he believes are responsible for the development of alcoholism. These include: 1 ) the discharge function (allowing expression of repressed impulses), 2) the narcotizing function (producing a state of stupor to prevent unpleasant stimuli from being conscious), 3) symbolic functions (attaching certain meaning to the toxic effects of alcohol), 4) the "infantomimetic" function (the recreation of various infantile experiences), 5) masochistic functions (hangover or other self-punishments), 6) hostility, 7) homosexuality, and 8) identification and identity (becoming an alcoholic helps to give the person a definite identity and role). ${ }^{22}$

$21_{\text {Ibid. , p. } 268 .}$

22Roebuck and Kessler, Op. Cit., p. 94. 
The transactional analysis approach to alcoholism is generally concerned with the interpersonal perspective of behavior. Keehn has suggested that:

...it is not necessarily alcohol per se that maintains excessive drinking, but reinforcing contingencies set up by the community, i.e. the interpersonal transactions brought on by the use of alcohol which provide the reinforcement. 23

For Claude Steiner, the reinforcement for alcoholic behavior comes from interpersonal payoffs (transactional responses) resulting from various games which are learned in order to carry out a life script. The motive for the various games is the payoff. Roebuck and Kessler note that:

Alcoholism is the result of alcoholic game playing. The transactional analysis perspective suggests that an alcoholic stranded on a desert island with a large supply of alcohol will stop drinking because drinking is only part of the transactional situation. Without other persons to transact with, the need for alcohol will disppear... This perspective is contrasted with the more traditional view that might predict that since the alcoholic's need for alcohol is due to an illness, the marooned alcoholic would still continue to drink. ${ }^{24}$

Steiner considers the game of "Alcoholic" as "part of a preconceived life plan which unfolds further with each renewed playing."25 Steiner describes three different types of alcoholic games which have certain common characteristics, but have unique characteristics, each of

${ }^{23}$ Ibid., p. 82 .

24 Ibid., p. 83.

${ }^{25}$ Claude Steiner; Games Alcoholics Play (New York: Ballantine Books, 1971), p. 85 . 
which is played by a certain kind of person.

The overall theme or life script for each of these games is a variation of "I am no good and I know it, but you are no good either, and since you don't seem to be aware of it, I am going to expose you."26 The weaknesses of others are exposed by luring people into the roles of patsy, persecutor or rescuer.

The first alcoholic game is entitled "Drunk and Proud of it" (D and P).

The specific thesis of 'Drunk and Proud of it' (D and P) is "You're good, I'm bad (try and stop me). Anyone who tries to stop the alcoholic from being bad will end up feeling definitely not O.K., feeling either foolish or angry.27

The alcoholic who plays this game is not at all interested in a rescuer to try to help him. Such a person is able to maintain most functions adequately, including occupational and social roles. He is primarily interested in frustrating significant others and in making them appear foolish. The typical "Drunk and Proud of it" player is rebelling against an:- overprotective parent or dominating spouse and is involved with alcohol in order to express his aggression without blame or feeling guilty.

The second game is called "Lush".

The thesis of the game is a variation of the 'I'm crazy (depressed), you can make me feel better (cure me) (ha, ha)'. It is usually played with a partner who is unable, or for whom it is difficult, to give strokes.

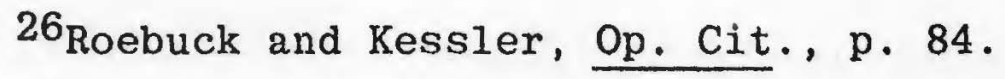
${ }^{27}$ Steiner, Op. Cit., p. 87. 
As a consequence, the Alcoholic's continued drinking is to the partner's advantage since as long as the drinking continues, his own emotional deficiency and his part in the game will not be exposed. The lush player is basically making a plea for strokes. But because these strokes will not be given by a partner under ordinary circumstances, he settles for the costly strokes that are given to him when he is rescued. 28

The game is played primarily by middle-aged suburban housewives, white-collar employees, and aging male homosexuals. Sexual deprivation is the common denominator. The lush feels that nobody loves him or her and the game is played in order to avoid inadequate feelings.

The last game is named "Wino".

'Wino' is always part of a self-destructive life script. The thesis 'I'm no good, you're o.K. (ha, ha)' is translated here to 'I'm sick (try to avoid that), you're well (ha, ha)'. The game of 'Wino' is played for keeps because it uses body organs and tissues as counter...The alcoholic obtains strokes by making himself physically ill... The payoff... is a confirmation of the position...I'm O.K., you're not O.K.. To the alcoholic, the fact that he must be at death's door to get supplies from people implies that those other people who are in positions of strength and power, are really not 0.K..29

For the wino, drinking to the point of physical and mental destruction forces others to help. He is saying that people in power positions wait until he is almost dead before they help, thus putting them in a position of not being $0 . \mathrm{K}$.

$$
\begin{aligned}
& { }^{28} \text { Ibid., p. } 93 . \\
& { }^{29} \text { Ibid., p. } 97 .
\end{aligned}
$$


This game is played by people who are considered to be orally deprived and the above activities with other players satisfy these needs.

Approaches to Treatment

The review of the literature reveals a variety of settings for approaches to the treatment of alcohol problems, perhaps a reflection of the several types of alcohol problems as noted earlier. Israel and Mardones provide a comprehensive examination of these various settings which are in common usage presently in the treatment of alcoholism. These settings include the general medical practitioners, general hospitals and the teaching medical center, private sanatoria and private hospitals, community mental health centers and alcoholism treatment clinics, and state hospitals such as Dammasch State Hospital. Each of these settings will be described in further detail below. Also, a review of recommended treatment settings for certain alcohol problems will be provided.

The first treatment setting described is the general practitioner who, according to Israel and Mardones, has been involved with a higher proportion of all the alcoholics. Advantages pointed out for general practitioners in working with alcoholics include their often extensive knowledge and history of the families in their community and the use of a team approach developed from knowledge of a community's resources.

The doctor's : effectiveness can be enhanced by 
the device of creating a team within his own community. This may consist of a clergyman who is clinically trained as a counsellor and who appreciates the problems of alcoholism and also by keeping in touch with public health nurses, employers, and others... Often one of the most successful therapeutic plans constitutes a team consisting of a general practitioner, a clergyman, and a member of Alcoholics Anonymous helping to bring the alcoholic and his family to treatment in a special setting. 30

The second setting described by Israel and Mardones is the general hospital and the teaching medical center. They indicated that it is often impossible to be admitted into a general hospital without a fictitious diagnosis, however, hospitals can offer successful detoxification procedures. It is their hope that no general hospital will be regarded as adequately serviced unless it has provisions for the care of alcoholics, including detoxification, group psychotherapy, individual psychotherapy, and other therapeutic modalities.

Private sanatoria and hospitals provide a third setting for the treatment of alcohol problems.

At their best, these institutions are a valuable resource in the community...At their worst, some of these institutions are simply rather poor drying-out centers with antiquated methods. Perhaps one of the greatest advantages (for private sanatoria) is that patients can be admitted to such services with a minimum of waiting...(and) they are a source of support to any alcoholics who could or would not avail themselves of other programs.31

30Yedy Israel and Jorge Mardones, Biological Basis of Alcoholism (New York: Wiley-Interscience, 1971), p. 297. ${ }^{31}$ Ibid., p. 400 . 
Community mental health centers and alcoholism treatment clinics are two other settings for treatment. These services have the advantage of bringing treatment close to where people live and work and typically offer group and individual therapy.

One last treatment setting described by Israel and Mardones is state hospitals which tend to have large proportions of alcoholics involved in treatment. Many of them provide "special wards...so that (alcoholics) can be more adequately cared for."32 Such hospitals often have group therapy programs as well as medical treatment.

One disadvantage of state hospital treatment that Israel and Mardones point out is that many state hospitals do not arrange continuing outpatient clinic treatment once their patients have been discharged to their communities. Looking specifically at Dammasch as a state hospital setting, it has already been mentioned earlier that the treatment of drug and alcohol problems normally comprises forty percent of the population at any one time. This. would support Israel and Mardones' statistics on the high proportion of alcoholics involved in treatment in state hospitals.

Dammasch, at the time of this research, had a group therapy program, as described earlier, which was separate from the rest of the hospital, although medical treatment

$$
32 \text { Ibid., p. } 401 .
$$


often occurred on other wards within the hospital.

To deal with the specific problem of adequate discharge planning from state hospitals, as mentioned by Israel and Mardones, Dammasch State Hospital had made attempts to arrange outpatient treatment as part of its Alcohol Treatment Program. All patients in the Alcohol Treatment Program were assigned to one of five counselors who would provide outpatient services for patients discharged fromithe program. It was hoped through this program that patients would be more willing to participate in outpatient treatment if they know the staff members who offered services such as individual and group treatment.

Although Israel and Mardones view state hospital treatment as being a setting which can be used as a viable resource for alcohol problems, some communities have attempted to de-emphasize or eliminate the use of such hospitals and keep alcoholism treatment in the community. Unlike the other settings described above, there appears to be much controversy in regard to the use of state hospitals for alcohol treatment, particularly institutions which are far removed from urban centers. San Francisco's Alcoholism Program is a case in point. This program is funded through the county, the State, and the Federal Vocational Rehabilitation Program and it involves "acute medical care and emergency service, screening, diagnostic and referral 
services, consultation, education, and evaluation."33

Medical, psychological, and social services have been developed within the city of San Francisco and this "has made it possible to reduce indiscriminate use of geographically removed state hospitals." 34

Some efforts have been made to identify which treatment settings are preferable for specific kinds of alcohol problems. Wanberg, Horn, and Fairchild have conducted studies to provide information leading to such recommendations. In one particular: study, they compared the effect of intensive inhospital treatment with that of incommunity treatment (mental health centers, alcohol treatment centers, etc.) with results that indicated, in terms of overall adjustment, inhospital treatment had a greater effect than a program of short term incommunity treatment. They noted, however, that community treatment was far more effective for some patients, and that both community and hospital treatments were ineffective for others. They also found that abstinence from drinking was not necessarily an indication of successful adjustment and they provided support, within their population, for controlled drinking as a goal. Arguments were stated "for further efforts to identify the kinds of problems

33Richard S. Shore, "Treat the Alcoholic, But not With Asylums", Research on Alcoholism: Clinical Problems and Special Populations, DHEW Publication No. 73-9074 (1973), p. 185 .

$$
34 \text { Ibid., p. } 185 .
$$


that: can best be treated with a particular form of therapy."35

Wanberg and Knapp have attempted, through empirical research, to identify successful treatment methods for specific alcohol problems by the development of a multi-dimensional model of alcoholism. It is based upon four different dimensions with specific recommendations for treatment. These dimensions and treatment recommendations are illustrated below.

The first group of alcoholics, described by Wanberg and Knapp, involves a broad severity of alcohol abuse. This group is characterized by continuous, chronic, and long-bout drinking. It is their belief that "any treatment program needs to serve a large number of persons who fit this broad dimension of alcoholism"36 and "the physical, social, and psychological impairment noted in this dimension calls for a rather comprehensive staff capable of meeting all these particular. needs."37 This group, they contend, might require extended stays in a residential treatment center.

The second group or dimension of alcoholics involves people who have had previous help for drinking problems and

35 Kenneth W. Wanberg, John L. Horn, and Donald Fairchild, "Hospital versus Community Treatment of Alcoholism Problems", International Journal of Mental Health, III (1974), p. 174.

${ }^{36}$ Kenneth W. Wanberg and John Knapp, "A Multi-dimensional Model for the Research and Treatment of Alcoholism", International Journal of Addictions, V (1970), p. 94.

${ }^{37}$ Ibid., p. 94 
use alcohol to relieve tension and to help in relating to people. The type of drinking pattern here would be a sustained, continuous style. As this group has attempted to find help from stress and tension, Wanberg and Knapp suggest that a general treatment goal would be to help them become aware of their reasons for seeking help and to work with the underlying stress that alcohol seems to be relieving: This group might benefit from not only a "drying out" center, but also a psychotherapeutic program, "for to merely sober up a person is to treat the symptom without attempting to deal with the underlying emotional and social difficulties."38

The third dimension involves people who use alcohol to enhance their self-esteem and show apparent psychosocial stress and anxiety, with alcohol being consumed to help cope with this anxiety. The drinking pattern is usually of a continuous fashion. Wanberg and Knapp feel that these "highly anxious persons need specific kinds of therapy designed to reduce anxiety and uncover its source." 39 They note that psychodrama has been useful for such people.

The last dimension involves people who drink either periodically or controlled, but in heavy amounts. These people typically have some stability in their lives, are married, and have jobs. Outpatient alcohol programs are recommended for this group.

$$
\begin{aligned}
& { }^{38} \text { Ibid., p. } 94 . \\
& { }^{39} \text { Ibid., p. } 94 .
\end{aligned}
$$


Demographic Studies of Alcohol Treatment Programs

Four demographic studies reviewed in the literature search seemed to relate to this present study and were considered to be the best examples of demographic studies on alcohol programs and patient populations. The four studies, to be explored in the following, include a study of England's alcohol treatment units, a study of the relationship between population characteristics of twenty Minnesota rural counties, a demographic study which examined fifty-five variables on persons applying for admission to the Fort Logan Center in Denver, Colorado, and a study which examined population variation among four different types of alcohol treatment facilities.

The first of these studies (Hore and Smith) involves alcohol treatment units in mental hospitals in England. The purpose of the study was to provide information on the type of clients passing through thirteen alcoholic units. A one page questionnaire (see Appendix C) was administered to a total of 334 patients, and it was deliberately made brief for the patients so as to prevent frustration and/or refusal. The data related to age and sex of the patient, type of secondary education, present and previous employment, occupation of spouse and parents, type of rearing in childhood and questions relating to social stability. It was also hoped that I.Q. could be recorded. Results indicated a mean age for men of 42 years and women of 40.3 years. Those who 
attended secondary school was 70.7 per cent of the sample. In relation to parental rearing, 85.3 percent were reared by one or both parents. Data suggested high stability levels in relationship to steady work record, living in "family accommodation and not drifting. $140^{\prime}$ This study provided the first glimpse of characteristics of patients using hospital alcohol treatment programs.

Hoffmann studied the relationship between population characteristics of 20 Minnesota rural counties, such as socioeconomical variables, and the admission rate to a state hospital for alcoholism treatment and for psychiatric disorders. The variables examined for the counties included median income, percent of poverty, percent of white collar labor, percent of farm population, percent of unemployement, median education, female fertility, and distance to a state hospital. Subjects included $1270 \mathrm{male}$ alcoholic and $112 \mathrm{fe}-$ male alcoholic admissions and 350 male and 447 female psychiatric admissions to a state hospital during years 1971 and 1972 .

Results showed that the rates of admission to a state hospital for alcoholic males was significantly correlated in a positive direction with the county's unemployment rate, education level and percentage of the native population and the distance to the state hospital. Female alcoholic admissions

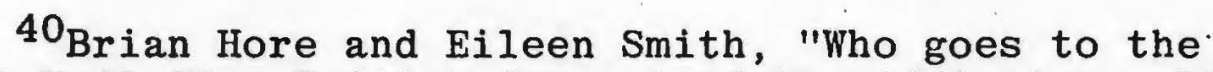
Alcohol Units?", British Journal of the Addictions, LXX
(1975), p. 268.' 
correlated with unemployment rate and education. The number of male psychiatric admissions correlated significantly and in a positive direction with the rate of unemployment and negatively with the distance to a state hospital. Only one significant correlation was found for female psychiatric patients, a negative one between admission and fertility rate. 41

Kanberg and Jones provide a demographic study which examines fifty-five variables measured on 267 persons applying for admission to the Fort Logan Center, Denver, Colorado, for alcoholism treatment. This treatment center offers a three-phase treatment program: 1) one week of 24 hour hospital care, 2) a second week of day hospital care, and 3) a third phase of evening group therapy on an out-patient basis. The study's statistics come from information taken on intake for reserving a hospital bed for the first phase of treatment. The variables were used to see if specific data related to whether a person showed for treatment.

The fifty-five variables included age, sex, social-cultural and socio-economic descriptions, religion, employment status, treatment history, marital status, referral sources and conditions surrounding intake, such as time during the day that the intake was completed, and the staff member's classification completing intake. Results indicated that

41 Helmut Hoffmann, "County Characteristics and Admission to State Hospital for Treatment of Alcoholism and Psychiatric Disorders", Psychological Reports, XXXV (1974), p. 1276. 
socio-economic status and sociological classification have little relationhip as to whether a person returns for treatments. These variables had no significant correlation tor, the curcumstances of the initial contact, such as the time of day the first contact was made, whether a family member accompanied the patient, or whether first contact was made in person or by phone. Self-referrals and those from major Protestant backgrounds tended not to return for treatment, and those having a family physican were more apt to follow through with treatment. If a person had to wait more than eight days before he could come for hospital admission, chances of he or she coming were reduced greatly. 42

One last study (Pattison, Coe, and Doerr) involved an examination of population variation among four alcoholism treatment facilities. Population characteristics were studied between patients admitted to an aversion-conditioning hospital, and outpatient clinic, a half-way house, and a police work center. Patients were interviewed to assess demographic charcteristics, characterological traits, life adaptation, and attitudes and expectations regarding treatment. They conclude that there may be predetermining factors that influence the selection of each facility by its client population. Further, they suggest that:

42 Kenneth W. Wanberg and Evelyn Jones, "Initial Contact and Admission of Persons Requesting Treatment for Alcohol Problems", British Journal of the Addictions, LXVII $(1973)$, p. 281. 
The data underscore the need to match facility philosophy and methods to the specific needs of alcoholic subpopulations. No one facility can provide a program that will meet the needs of all alcoholic subpopulations. In the planning and implementation of comprehensive community alcoholism programs there is a need for multiple treatment approaches. This should be construed as complementary facilities serving particular population needs, rather than competitive facilities seeking to see who can 'do it best.' 43

${ }^{43}$ H.M. Pattison, R. Coe, and H. O. Doerr, "Population Variation among Alcoholism Treatment Facilities", International Journal of the Addictions, VIII (1973), p. 200 . 
CHAPTER III

\section{METHODOLOGY}

The demographic information gathered in this research project is to be used in assessing the possible need of diversified treatment programs for alcoholic patients at Dammasch and in the Portland community. The two populations studied were patients at Dammasch who participated in the Alcohol Treatment Program and patients at the hospital who were not participating in the specialized program. It was indicated to this researcher that the data could be particularly useful in developing treatment programs for patients at the hospital who were not receiving special services for their alcohol problem.

Methods for collecting data were discussed with the thesis committee and staff at Dammasch State Hospital. The consensus was that a questionnaire would be the most appropriate tool for gathering data. Staff members of the Alcohol Treatment Program and Multonmah County Drug and Alcohol Division were consulted in a meeting to discuss the areas of demographic data which were considered to be relevant for their needs and interest. The three general topics of interest by this group included: 1) the social background of the patient, 2) the history of alcohol use by each participant, and 3) a psychological/medical history.

Under the heading of social background, staff members were interested in demographic information such as age, sex, 
ethnic group, number of brothers and sisters, education of the mother and father, education of the patient, employment, marital status, number of children, religious preference, and any history of arrests.

For the category of alcohol background, information was requested on the patient's drinking pattern; amount of alcohol consumed; reasons for drinking; reactions to alcohol; and some indication of helpful methods for treatment as viewed by the patients.

The last category (medical/psychological background) involved previous hospitalizations for alcohol abuse, community treatment for alcohol abuse (such as a mental health clinic, alcohol treatment clinic, etc.), current state of physical health, a list of any major medical or psychiatric problems treated, current medications, how the patient heard about the Alcohol Treatment Program at Dammasch State Hospital, and an indication of the patient's preference for inpatient treatment within or outside of a state hospital.

Several questionnaires dealing with alcoholism were found during the literature review, however, none of them, as entities within themselves, covered all the areas recommended by the hospital staff and Multnomah County for the questionnaire. This required the development of a questionnaire based on questions (taken directly or paraphrased) from published questionnaires plus the addition of new questions to complete the recommended format. Sources used for the 
final form of the administered questionnaire are included in Appendix A.

The first draft of the questionnaire was submitted to the thesis committee. After recommendations for changes were completed, the questionnaire was given a pretest. The questionnaire was administered to five patients who volunteered in the alcohol program and five patients who volunteered outside of the program in order to make further adjustments to the questionnaire such as removing confusing language, deleting questions, and adding questions. These changes were made through comments requested from the ten patients directly after they took the questionnaire. The final form was reduced from 91 questions to 73 questions (see Appendix B).

In examining the usefulness of this final form of the questionnaire when administered, several disadvantages were encountered. First of all, the length of the instrument (73 questions in total) took twenty minutes to one-half hour to be completed by the patients who volunteered. There were eight patients who became frustrated, did not finish the questionaires and, thus, they could not be used for the study. Some patients refused to take the questionnaire at all because they felt it would take too long to complete. Secondly, the questionnaire was based on an assumption that patients would provide valid responses to the material presented to them, however, no method was developed to provide a way to insure factual responses. 
Of the advantages observed from the use of this questionnaire, the most important would be that the instrument was designed to provide specific information from the population. Also, another advantage was the relative ease in tabulating the data. Most of the questions were categorical rather than open-ended questions.

Looking beyond the development of the questionnaire, the next major decisions involved the process of administering the questionnaire to the larger population to be studied. The thesis committee and the staff at Dammasch State Hospital suggested that the questionnaire could be given in groups of patients rather than individually. It was recommended that the patients understand that they could take the questionnaire only. if they wished to participate. It was also suggested that an explanation be given of how the questionnaire would be used and to stress that the information would be confidential. Before the questionnaire was administered to a group of patients, instructions for using the questionnaire were to be explained.

The thesis committee recommended that at least thirty patients take the questionnaire who were participants in the Alcohol Treatment Program and at least thirty patients who were not praticipating in the specialized program. Due to circumstances beyond the reseacher's control, a decision was made to administer the questionnaire during the month of June, 1976. The number of possible patients to be 
interviewed totaled thirty-six in the Alcohol Treatment Program and forty who were not participating in the program.

The above recommendations were followed and the questionnaire was first administered to patients in the Alcohol Treatment Program in small groups. Patients were told that this was on a voluntary basis and they were informed that the information would be used for the partial fulfillment of the researcher's graduate program. It was also stressed that the patient's name was not to be written on the questionnaire in order to keep the information confidential. The instructions on the top of the questionnaire (see Appendix B) were read and it was made known that the researcher was available to answer questions while the patients were taking the questionnaire. The size of the groups varied from as few as three patients to as many as ten. The final number of patients who were willing to take the questionnaire was twenty-five.

Patients on other wards who were not participating in the specialized program were administered the questionnaire during the same month of June and the process described above was used in administering the questionnaire. Twenty-five patients were found who were willing to take the questionnaire and a decision was made to keep the number of patients equal with the twenty-five patients in the alcohol program who were willing to take the questionnaire.

An attempt was made to administer the questionnaire in small groups as had been done on the Alcohol Treatment 
Program ward, however, procedure varied on the different wards: When there were several patients who were interested in taking the questionnaire on the same ward, a small group was formed with all participants taking the questionnaire in the prescence of the researcher. On other occasions, only one patient expressed interest on some of the general wards, and the questionnaire was given individually.

Toward the end of the:month of June, a further attempt was made to increase the number of patients for each population, but no patients were located who were willing to take the questionnaire, thus, each population remained at twentyfive patients.

There were several methodological problems encountered during the administering of the questionnaire. The original plan for this demographic study was to interview a population of at least thirty patients for each group to be studied--a total of sixty patients. Data was to have been collected over a period of at least four months in order to insure a more typical, characteristic population of alcoholic patients.

Several circumstances interfered with the use of this projected plan. First of all, the Alcohol Treatment Program personnel were uncertain of the program's refunding at the time the study was initiated. A decision was made to proceed with the study on an assumption that the program probably would not receive further operating funds. This gave the researcher only one month (June, 1976) to collect data. The program personnel was given five days notification 
that additional funds had not been located for its continuation, thus, collection of data had to cease once the program was terminated.

A second problem involved the condition of the alcoholic population at Dammasch State Hospital during the time of data collection. The census of patients with a diagnosis of alcoholism. was considerably below the normal level for the hospital which interfered with the desired goal of locating sixty volunteers for the study. Speculation for the lowered alcoholic population could have involved the possible closing of the Alcohol Treatment Program and the summer season which has often meant fewer alcoholics in the hospital than during other seasons.

An arbitrary decision was made to strive for twenty-five patients per group instead of the previously desired goal of thirty per group. The lowered number of subjects was successfully obtained.

The above changes in data collection created restrictions in analyzing the results. Information gathered could not be generalized beyond the fifty patients tested for the month of June, 1976, because there were no assurances that a typical, characteristic sample had been tested. The researcher was not able to get a random sample and he simply had to gather what was available. It is possible that there may have been people who would have been willing to take the questionnaire but were somehow overlooked. 
An additional problem involved having only one group with males and females while the other group was totally males. This was due to the difficulty of locating any females who were not participating in the Alcohol Treatment Program and who were also willing to participate in this study. At the time of the study, there were only five females who weren't participating in the program and all of them refused to take the questionnaire. The result was no non-treatment comparison for females.

The research was continued to provide assistance in further planning at Dammasch State Hospital and Multnomah County for future service delivery. 


\section{CHAPTER IV}

\section{RESULTS}

This research project has been designed to discuss descriptive characteristics of alcoholic patients in an alcohol program at Dammasch State Hospital and alcoholic patients who were not participating in the program. The results from the data collection will indicate similarities and differences in social background, alcohol background, and medical/psychological history for the two patient populations. The results will be given in the forms of tables and narrative. Because of the number of tables, the reader will be referred to Appendix $D$ for some of the data. The questionnaire used for the collection of data can be found in Appendix B.

\section{Social Background}

There was a total of 50 patients who participated in the study. The patients included 17 program males, 8 program females, and 25 non-program males.

A comparison of ages between program males, program females, and non-program males is presented in Table I.

For program males, there was no one over the age of 55 . Most of the patients were in the age range of 26-35 and 46-55. For non-program males, ages were more evenly spread out, including 2 patients in the age range of 56-65. Only 1 program female was in the age range of 56-65, while all the others in this group were between the younger ages of 16-45. 
TABLE I

PATIENTS' AGES

\begin{tabular}{|c|c|c|c|c|c|c|c|c|}
\hline \multirow[t]{2}{*}{ Ages } & \multicolumn{2}{|c|}{ Program Males } & \multicolumn{2}{|c|}{ Program Females } & \multicolumn{2}{|c|}{ Sub-Total } & \multicolumn{2}{|c|}{ Non-Program Males } \\
\hline & $\begin{array}{r}\text { Freq.of } \\
\text { response } \\
\end{array}$ & Percent & $\begin{array}{l}\text { Freq. of } \\
\text { response }\end{array}$ & Percent & $\begin{array}{l}\text { Freq. of } \\
\text { response }\end{array}$ & Percent & $\begin{array}{l}\text { Freq. of } \\
\text { fesponse }\end{array}$ & Percent \\
\hline $16-25$ & 2 & $11.7 \%$ & 3 & $37.5 \%$ & 5 & $20.0 \%$ & 5 & $20.0 \%$ \\
\hline $26-35$ & 6 & $35.3 \%$ & 2 & $25.0 \%$ & 3 & $32.0 \%$ & 7 & $28.0 \%$ \\
\hline $36-45$ & 3 & $17.6 \%$ & 2 & $25.0 \%$ & 5 & $20.0 \%$ & 6 & $24.0 \%$ \\
\hline $46-55$ & 5 & $29.4 \%$ & 0 & $0.0 \%$ & 5 & $20.0 \%$ & 5 & $20.0 \%$ \\
\hline $56-65$ & 0 & $0.0 \%$ & 1 & $12.5 \%$ & 1 & $4.0 \%$ & 2 & $8.0 \%$ \\
\hline No answer & 1 & $5.8 \%$ & 0 & $0.0 \%$ & 1 & $4.0 \%$ & 0 & $0.0 \%$ \\
\hline Total & 17 & $99.8 \%^{*}$ & 8 & $100.0 \%$ & 25 & $100.0 \%$ & 25 & $100.0 \%$ \\
\hline
\end{tabular}

* Does not equal $100.0 \%$ due to rounding error. 
Regarding ethnic groups, eighty-eight percent of the program males were Caucasian, $75.0 \%$ of the program females were Caucasian, and $84.0 \%$ of the non-program males were Caucasian. The other patients included 4 Blacks, 2 MexicanAmericans, and 1 American Indian. One patient responded to "other", and didn't specify a specific ethnic group (see Appendix D, Table XXIX). Over half of all the patients resided with their parents for most of their early life. Eighty percent of the program patients and $84.0 \%$ of the nonprogram patients had lived primarily with their parents. Regarding siblings, $28.0 \%$ of the program patients and $32.0 \%$ of the non-program patients had no brothers. Sixteen percent of the program patients and $20.0 \%$ of the non-program patients had no sisters. All other patients had brothers and/or sisters (see Appendix D. Tables XXX, XXXI, and XXXII).

Table II illustrates the order of sibling birth for patients in the study.

For program males, $52.9 \%$ indicated that they had been in the middle in order of sibling birth. There were $75.0 \%$ of the program females who were the oldest and $44.0 \%$ of the non-program males who were the youngest.

The occupations for the fathers of the patients were varied, however, $40.0 \%$ of the non-program males indicated that their fathers were laborers. There were $11.7 \%$ of the program males and $12.5 \%$ of the program females had fathers who were laborers. The occupation most frequently mentioned for mothers was housewife for all categories of patients (see 
TABLE II

ORDER OF SIBLING BIRTH

\begin{tabular}{|c|c|c|c|c|c|c|c|c|}
\hline \multirow{2}{*}{$\begin{array}{c}\text { Order } \\
\text { of } \\
\text { Birth }\end{array}$} & Program & Males & \multicolumn{2}{|c|}{ Program Females } & \multicolumn{2}{|c|}{ Sub-Total } & \multicolumn{2}{|c|}{ Non-Program Males } \\
\hline & $\begin{array}{l}\text { Freq. of } \\
\text { response }\end{array}$ & Percent & $\begin{array}{l}\text { Freq. of } \\
\text { response }\end{array}$ & Percent & $\begin{array}{l}\text { Freq. of } \\
\text { response }\end{array}$ & Percent & $\begin{array}{l}\text { Freq. of } \\
\text { response }\end{array}$ & Percent \\
\hline Youngest & 3 & $17.6 \%$ & 0 & $0.0 \%$ & 3 & $12.0 \%$ & 11 & $44.0 \%$ \\
\hline Middle & 9 & $52.9 \%$ & 0 & $0.0 \%$ & 9 & $36.0 \%$ & 8 & $32.0 \%$ \\
\hline Oldest & 1 & $11.7 \%$ & 6 & $75.0 \%$ & 8 & $32.0 \%$ & 4 & $16.0 \%$ \\
\hline $\begin{array}{l}\text { I was the } \\
\text { only child }\end{array}$ & 3 & $17.6 \%$ & 1 & $12.5 \%$ & 4 & $16.0 \%$ & 2 & $8.0 \%$ \\
\hline No answer & 0 & $0.0 \%$ & 1 & $12.5 \%$ & 1 & $4.0 \%$ & 0 & $0.0 \%$ \\
\hline Total & 17 & $99.8 \%$ & -8 & $100.0 \%$ & 25 & $100.0 \%$ & 25 & $100.0 \%$ \\
\hline
\end{tabular}

* Does not equal $100.0 \%$ due to rounding error 
Appendix D. Tables XXXIII and XXXIV which includes a list of occupations).

Tables III and IV provide information in regard to the levels of education for the parents of patients involved in the study.

Most of the parents of these patients had either a grade school or high school education. A small percentage of parents had received education beyond the high school level. Differences between the groups were slight.

Levels of education for patients are presented in Table V.

For the program patients, $44.0 \%$ had attended high school compared with $52.0 \%$ of the non-program patients. There was no variation for the categories of grade school (20.0\% for program and non-program patients) and "some college:"' ( $24.0 \%$ for both groups).

Primary sources of income for patients are shown in Table VI.

Most program males $(64.7 \%)$ and non-program males (64.0\%) indicated that their usual source of income was through employment, while only one (12.0\%) of the program females indicated that employment was usually the main source of income. There were $37.5 \%$ of the program females who receired public support and $37.5 \%$ who received family support.

Although the percentages of patients who claimed that employment was the usual source of income were $48.0 \%$ for 
TABLE III

HIGHEST LEVEL OF EDUCATION OF PATIENTS' FATHERS

\begin{tabular}{|c|c|c|c|c|c|c|c|c|}
\hline \multirow{2}{*}{$\begin{array}{l}\text { Level of } \\
\text { education- } \\
\text { of father } \\
\end{array}$} & \multicolumn{2}{|c|}{ Program Males } & \multicolumn{2}{|c|}{ Program Females } & \multicolumn{2}{|c|}{ Sub-Total } & \multicolumn{2}{|c|}{ Non-Program Males } \\
\hline & $\begin{array}{l}\text { Freq. of } \\
\text { response }\end{array}$ & Percent & $\begin{array}{l}\text { Freq. of } \\
\text { response }\end{array}$ & Percent & $\begin{array}{l}\text { Freq. of } \\
\text { response }\end{array}$ & Percent & $\begin{array}{l}\text { Freq. of } \\
\text { response }\end{array}$ & Percent \\
\hline Grades 1-8 & 8 & $47.0 \%$ & 2 & $25.0 \%$ & 10 & $40.0 \%$ & 10 & $40.0 \%$ \\
\hline Grades $9-12$ & 7 & $41.1 \%$ & 3 & $37.5 \%$ & 10 & $40.0 \%$ & $\therefore 5$ & $20.0 \%$ \\
\hline Some coll. & 1 & $5.8 \%$ & 2 & $25.0 \%$ & 3 & $12.0 \%$ & 2 & $8.0 \%$ \\
\hline $\begin{array}{l}\text { Tech. or } \\
\text { Bussiness sd }\end{array}$ & 0 & $0.0 \%$ & 1 & $12.5 \%$ & 1 & $4.0 \%$ & 0 & $0.0 \%$ \\
\hline I don't know & 0 & $0.0 \%$ & 0 & $0.0 \%$ & 0 & $0.0 \%$ & 6 & $24.0 \%$ \\
\hline Other & 0 & $0.0 \%$ & 0 & 0.0 & 0 & 0.0 & $1 * *$ & $4.0 \%$ \\
\hline No answer & 1 & $5.8 \%$ & 0 & $0.0 \%$ & 1 & $4.0 \%$ & 1 & $4.0 \%$ \\
\hline Tota1 & 17 & $99.7 \%$ & 8 & $100.0 \%$ & 25 & $100.0 \%$ & 25 & $100.0 \%$ \\
\hline
\end{tabular}

* Does not equal $100.0 \%$ due to rounding error

** "none" 
TABLE IV

HIGHEST LEVEL OF EDUCATION OF PATIENTS' MOTHERS

\begin{tabular}{|c|c|c|c|c|c|c|c|c|}
\hline \multirow{2}{*}{$\begin{array}{l}\text { Level of } \\
\text { Education } \\
\text { of Mother }\end{array}$} & \multicolumn{2}{|c|}{ Program Males } & \multicolumn{2}{|c|}{ Program Females } & \multicolumn{2}{|c|}{ Sub-Total } & \multicolumn{2}{|c|}{ Non-Program Males } \\
\hline & $\begin{array}{l}\text { Freq. of } \\
\text { response }\end{array}$ & Percent & $\begin{array}{l}\text { Freq of } \\
\text { mesponce }\end{array}$ & Percent & $\begin{array}{l}\text { Freq. of } \\
\text { cesponce }\end{array}$ & Percent & $\begin{array}{l}\text { Freq. of } \\
\text { responce }\end{array}$ & Percent \\
\hline Grades 1-8 & 7 & $41.0 \%$ & 2 & $25.0 \%$ & 9 & $36.0 \%$ & 6 & $24.0 \%$ \\
\hline Grades 9-12 & 4 & $23.5 \%$ & 2 & $25.0 \%$ & 6 & $24.0 \%$ & 8 & $32.0 \%$ \\
\hline Some college & 1 & $5.8 \%$ & 1 & $12.5 \%$ & 2 & $8.0 \%$ & 2 & $8.0 \%$ \\
\hline $\begin{array}{l}\text { Bachelor's } \\
\text { Degree }\end{array}$ & 1 & $5.8 \%$ & 0 & $0.0 \%$ & 1 & $4.0 \%$ & 1 & $4.0 \%$ \\
\hline $\begin{array}{l}\text { Tech. or } \\
\text { Business Sc1 }\end{array}$ & 0 & $0.0 \%$ & 2 & $25.0 \%$ & 2 & $8.0 \%$ & 0 & $0.0 \%$ \\
\hline Don't Know & 4 & $23.5 \%$ & 1 & $12.5 \%$ & 5 & $20.0 \%$ & 6 & $24.0 \%$ \\
\hline No Answer & 0 & $0.0 \%$ & 0 & $0.0 \%$ & 0 & $0.0 \%$ & 2 & $8.0 \%$ \\
\hline Total & 17 & $99.7 \%$ & 8 & $100.0 \%$ & 25 & $100.0 \%$ & 25 & $100.0 \%$ \\
\hline
\end{tabular}

* Does not equal $100.0 \%$ due to rounding error. 
TABLE V

HIGHEST LEVEL OF EDUCATION OF PATIENTS

\begin{tabular}{|c|c|c|c|c|c|c|c|c|}
\hline \multirow{2}{*}{$\begin{array}{l}\text { Level of } \\
\text { Education } \\
\text { of } \\
\text { Patients } \\
\end{array}$} & \multicolumn{2}{|c|}{ Program Males } & \multicolumn{2}{|c|}{ Program Females } & \multicolumn{2}{|c|}{ Sub-TotaI } & \multicolumn{2}{|c|}{ Non-Program Males } \\
\hline & $\begin{array}{l}\text { Freq. of } \\
\text { response }\end{array}$ & Percent & $\begin{array}{l}\text { Freq. of } \\
\text { response }\end{array}$ & Percent & $\begin{array}{l}\text { Freq. of } \\
\text { responss }\end{array}$ & Percent & $\begin{array}{l}\text { req. of } \\
\text { response }\end{array}$ & Percent \\
\hline Grades 1-8 & 4 & $23.5 \%$ & 1 & $12.5 \%$ & 5 & $20.0 \%$ & 5 & $20.0 \%$ \\
\hline Grades 9-12 & 8 & $47.0 \%$ & 3 & $37.5 \%$ & 11 & $44.0 \%$ & 13 & $52.0 \%$ \\
\hline Some College & 3 & $17.6 \%$ & 3 & $37.5 \%$ & 6 & $24.0 \%$ & 6 & $24.0 \%$ \\
\hline $\begin{array}{l}\text { Tech. or } \\
\text { Business Scl }\end{array}$ & 2 & $11.7 \%$ & 1 & $12.5 \%$ & 3 & $12.0 \%$ & 0 & $0.0 \%$ \\
\hline G.E.D. & 0 & $0.0 \%$ & 0 & $0.0 \%$ & 0 & $0.0 \%$ & 1 & $4.0 \%$ \\
\hline No Answer & 0 & $0.0 \%$ & 0 & $0.0 \%$ & 0 & $100.0 \%$ & 0 & $0.0 \%$ \\
\hline Total & 17 & $99.8 \%^{*}$ & 8 & $100.0 \%$ & 25 & & 25 & $100.0 \%$ \\
\hline
\end{tabular}

* Does not equal $100.0 \%$ due to rounding error 
TABLE VI

MAIN SOURCE OF INCOME

\begin{tabular}{|c|c|c|c|c|c|c|c|c|}
\hline \multirow{2}{*}{$\begin{array}{l}\text { Source of } \\
\text { Income }\end{array}$} & \multicolumn{2}{|c|}{ Program Males } & \multicolumn{2}{|c|}{ Program Females } & \multicolumn{2}{|c|}{ Sub-TotaI } & \multicolumn{2}{|c|}{ Non-Program Males } \\
\hline & $\begin{array}{l}\text { Freq. of } \\
\text { response }\end{array}$ & Percent & \begin{tabular}{|l|} 
Freq. of \\
response \\
\end{tabular} & Percent & $\begin{array}{l}\text { Freq. of } \\
\text { response }\end{array}$ & Percent & \begin{tabular}{|l|}
$\begin{array}{l}\text { Freq. of } \\
\text { respponse }\end{array}$ \\
\end{tabular} & Percent \\
\hline Pub. Support & 4 & $23.5 \%$ & 3 & $37.5 \%$ & 7 & $28.0 \%$ & 2 & $8.0 \%$ \\
\hline Family suprt. & 1 & $5.8 \%$ & 3 & $37.5 \%$ & 4 & $16.0 \%$ & 2 & $8.0 \%$ \\
\hline Pmployment & 11 & $64.7 \%$ & 1 & $12.5 \%$ & 12 & $48.0 \%$ & 16 & $64.0 \%$ \\
\hline $\begin{array}{l}\text { Other } \\
\text { Self-Support }\end{array}$ & 1 & $5.8 \%$ & 1 & $12.5 \%$ & 2 & $8.0 \%$ & 4 & $16.0 \%$ \\
\hline No Answer & 0 & $0.0 \%$ & 0 & $0.0 \%$ & 0 & $0.0 \%$ & 1 & $4.0 \%$ \\
\hline Total & 17 & $99.8 \% *$ & 8 & $100.0 \%$ & 25 & $100.0 \%$ & 25 & $100.00 \%$ \\
\hline
\end{tabular}

* Does not equal $100.0 \%$ due to rounding error. 
program patients and $64.0 \%$ for non-program patients, over half of the patients for both groups were not employed at the time of admission to the hospital. Eighty percent of the program patients and $84.0 \%$ of the non-program patients were not working (see Appendix D. Table XXXV and Table XXXVI).

Of those program patients who had been employed, $40.0 \%$ had held 1-2 jobs within the past year, and $60.0 \%$ of the non-program patients had held 1-2 jobs within the past year. A small percentage of patients from both groups had held more than two jobs within the year (see Appendix D., Table XXXVII).

In terms of annual income, the largest percentage of patients had incomes which were under $\$ 3,000$. This in-. cluded $36.0 \%$ of the program patients and $28.0 \%$ of the nonprogram patients (see Appendix D., Table XXXVIII).

There were $52.0 \%$ of the program patients who owed debts before entering Dammasch State Hospital compared with 48. $0 \%$ of the non-program patients. All others stated that they had no debts except for 2 of the program patients (male and female) who didn't answer the question.

Table VII provides data on marital status for the alcoholic patients.

Forty percent of the program patients were single at the time of admission to the hospital, while 2 of the non-program patients, $(8.0 \%)$ were single. Of the program patients, $36.0 \%$ had been divorced compared with $48.0 \%$ of the 
TABLE VII

CURRENT MARITAL STATUS

\begin{tabular}{|c|c|c|c|c|c|c|c|c|}
\hline \multirow{2}{*}{$\begin{array}{l}\text { Marital } \\
\text { Status }\end{array}$} & \multicolumn{2}{|c|}{ Program Males } & \multicolumn{2}{|c|}{ Program Females } & \multicolumn{2}{|c|}{ Sub-Total } & \multicolumn{2}{|c|}{ Non-Program Males } \\
\hline & $\begin{array}{l}\text { Freq. of } \\
\text { response }\end{array}$ & Percent & $\begin{array}{l}\text { Freq. of } \\
\text { response }\end{array}$ & Percent & $\begin{array}{l}\text { Freq. of } \\
\text { response }\end{array}$ & Percent & $\begin{array}{l}\text { Freq. of } \\
\text { responce }\end{array}$ & Percent \\
\hline Single & 7 & $41.2 \%$ & 3 & $37.5 \%$ & 10 & $40.0 \%$ & 2 & $8.0 \%$ \\
\hline Married & 3 & $17.6 \%$ & 1 & $12.5 \%$ & 4 & $16.0 \%$ & 3 & $12.0 \%$ \\
\hline Divorced & 6 & $35.3 \%$ & 3 & $37.5 \%$ & 9 & $36.0 \%$ & 12 & $48.0 \%$ \\
\hline Separated & 1 & $5.8 \%$ & 1 & $12.5 \%$ & 2 & $8.0 \%$ & 6 & $24.0 \%$ \\
\hline widowed & 0 & $0.0 \%$ & 0 & $0.0 \%$ & 0 & $0.0 \%$ & 1 & $4.0 \%$ \\
\hline remarried & 0 & $0.0 \%$ & 0 & $0.0 \%$ & 0 & $0.0 \%$ & 0 & $0.0 \%$ \\
\hline non-legal & 0 & $0.0 \%$ & 0 & $0.0 \%$ & 0 & $0.0 \%$ & 1 & $4.0 \%$ \\
\hline Total & 17 & $99.7 \%$ & 8 & $100.0 \%$ & 25 & $100.0 \%$ & 25 & $100.0 \%$ \\
\hline
\end{tabular}

* Does not equal $100.0 \%$ due to rounding error. 
program patients (see Appendix D., Table XXXIX).

Data on those patients who did or did not have children are presented in Appendix D., Table XL.

The percentages of children in pre-school, grade school, high school, college, and post-college have not been compared due to difficulty in interpreting the results.

The largest percentage of patients were Protestant (40.0\% for program patients and $44.0 \%$ for non-program patients). There were $36.0 \%$ of the program patients who had no specified religious group compared with $28.0 \%$ of nonprogram patients. There were $40.0 \%$ of the program patients who attended church only rarely compared with $44.0 \%$ of the non-program patients. All other categories for church attendance received fewer responses (see Appendix D., Tables XLL and XLII).

Table VIII shows the percentage of patients who participated in various recreational activities.

There were $56.0 \%$ of the program patients who had no hobbies compared with $80.0 \%$ of the non-program patients with no hobbies (see Appendix D., Table XLIII for a list of hobbies described by those patients participating in recreational activities).

Twenty percent of patients from both groups had lived in Oregon for over ten years. Thirty-six percent of the program patients and $28.0 \%$ of the non-program patients had lived in Oregon all their lives. In regard to the number of moves made in the past year, $52.0 \%$ of both groups either 


\section{TABLE VIII}

HOBBIES OR RECREATIONAL ORGANIZATIONS

\begin{tabular}{|c|c|c|c|c|c|c|c|c|}
\hline \multirow{2}{*}{$\begin{array}{l}\text { Hobbies or } \\
\text { recreational } \\
\text { organization }\end{array}$} & \multirow{2}{*}{$\begin{array}{l}\text { Program } \\
\text { Freq. of } \\
\text { response }\end{array}$} & \multirow{2}{*}{$\begin{array}{l}\text { Males } \\
\text { Percent }\end{array}$} & \multicolumn{2}{|c|}{ Program Females } & \multicolumn{2}{|c|}{ Sub-Total } & \multicolumn{2}{|c|}{ Non-Program Males } \\
\hline & & & $\begin{array}{l}\text { Freq. of } \\
\text { response }\end{array}$ & Percent & $\begin{array}{l}\text { Freq. of } \\
\text { response }\end{array}$ & Percent & $\begin{array}{l}\text { Freq. of } \\
\text { response }\end{array}$ & Percent \\
\hline Yes & 6 & $35.3 \%$ & 4 & $50.0 \%$ & 10 & $40.0 \%$ & 5 & $20.0 \%$ \\
\hline No & 11 & $64.7 \%$ & 3 & $37.5 \%$ & 14 & $56.0 \%$ & 20. & $80.0 \%$ \\
\hline No answer & 0 & $0.0 \%$ & 1 & $12.5 \%$ & 1 & $4.0 \%$ & 0 & $0.0 \%$ \\
\hline Total & 17 & $100.0 \%$ & 8 & $100.0 \%$ & 25 & $100.0 \%$ & 25 & $100.0 \%$ \\
\hline
\end{tabular}


didn't move at all or moved 1-2 times. (see Appendix D., Table XLIV and XLV).

For both patient groups, $32.0 \%$ had been in the Portland Detoxification Center before coming in the hospital, while $68.0 \%$ of the program patients and $64.0 \%$ of the non-program patients had not been in Detox (see Appendix D., Table XLVI).

Table IX provides a comparison of living situations between program and non-program patients.

There were $24.0 \%$ of the program patients living alone, while $44.0 \%$ of the non-program patients lived alone. Those who lived with friends included $32.0 \%$ of the program patients and $24.0 \%$ of the non-program patients. When program males and program females were compared in regard to living with friends, the statistics were $17.6 \%$ and $62.5 \%$ respectively. Only $12.0 \%$ of the program patients and $8.0 \%$ of the nonprogram patients were living with a spouse.

There were $40.0 \%$ of the program patients and $32.0 \%$ of the non-program patients who felt that they had no friends living in their community. Four patients from both groups (16.0\% each) felt they had 6 or more friends (see Appendix D., Table XLVII).

Regarding arrests for intoxication related charges, $64.0 \%$ of the program patients and $56.0 \%$ of the non-program patients had never been arrested for anything else during the past year (see Appendix D., Table XLVIII and XLIX).

Table $X$ provides data on patients who have spent time in a penitentiary. 
TABLE IX

LIVING SITUATION A MONTH BEFORE ENTERING THE HOSPITAL

\begin{tabular}{|c|c|c|c|c|c|c|c|c|}
\hline \multirow{2}{*}{$\begin{array}{l}\text { Living } \\
\text { Situation }\end{array}$} & \multicolumn{2}{|c|}{ Program Males } & \multicolumn{2}{|c|}{ Program Females } & \multicolumn{2}{|c|}{ Sub-Total } & \multicolumn{2}{|c|}{ Non-Program Male } \\
\hline & $\begin{array}{l}\text { Freq. Of } \\
\text { response }\end{array}$ & Percent & $\begin{array}{l}\text { req. of } \\
\text { response }\end{array}$ & Percent & $\begin{array}{l}\text { Freq. of } \\
\text { response }\end{array}$ & Percent & $\begin{array}{l}\text { Freq. of } \\
\text { response }\end{array}$ & Percent \\
\hline Living Alone & 5 & $29.4 \%$ & 1 & $12.5 \%$ & 6 & $24.0 \%$ & 11 & $44.0 \%$ \\
\hline With Friends & 3 & $17.6 \%$ & 5 & $62.5 \%$ & 8 & $32.0 \%$ & 6 & $24.0 \%$ \\
\hline With Spouse & 2 & $11.7 \%$ & 1 & $12.5 \%$ & 3 & $12.0 \%$ & 2 & $8.0 \%$ \\
\hline With Relatives & 5 & $29.4 \%$ & 1 & $12.5 \%$ & 6 & $24.0 \%$ & 3 & $12.0 \%$ \\
\hline other & $2^{*}$ & $11.7 \%$ & 0 & $0.0 \%$ & 2 & $8.0 \%$ & $2^{* * *}$ & $8.0 \%$ \\
\hline No Answer & 0 & $0.0 \%$ & 0 & $0.0 \%$ & 0 & $0.0 \%$ & 1 & $4.0 \%$ \\
\hline Total & 17 & $99.8 \%^{* *}$ & 8 & $100.0 \%$ & 25 & $100.0 \%$ & 25 & $100.0 \%$ \\
\hline
\end{tabular}

* Halfway house

** Does not equal $100.0 \%$ due to rounding error.

*** With girlfriend 
TABLE X

TIME SPENT IN A PENITENTIARY

\begin{tabular}{|c|c|c|c|c|c|c|c|c|}
\hline \multirow{2}{*}{$\begin{array}{l}\text { Any } \\
\text { in } \\
\text { Pen. }\end{array}$} & \multicolumn{2}{|c|}{ Program Males } & \multicolumn{2}{|c|}{ Program Females } & \multicolumn{2}{|c|}{ Sub-Total } & \multicolumn{2}{|c|}{ Non-Program Males } \\
\hline & $\begin{array}{l}\text { Freq.of } \\
\text { response }\end{array}$ & Percent & $\begin{array}{l}\text { Freq. of } \\
\text { response }\end{array}$ & Percent & $\begin{array}{l}\text { Freq. of } \\
\text { response }\end{array}$ & Percent & $\begin{array}{l}\text { Freq. of } \\
\text { response }\end{array}$ & Percent \\
\hline Yes & 4 & $23.5 \%$ & 0 & $0.0 \%$ & 4 & $16.0 \%$ & 9 & $36.0 \%$ \\
\hline No & 13 & $76.5 \%$ & 1 & $12.5 \%$ & 20 & $80.0 \%$ & 16 & $64.0 \%$ \\
\hline No answer & 0 & $0.0 \%$ & 1 & $4.0 \%$ & 1 & $4.0 \%$ & 0 & $0.0 \%$ \\
\hline Total & 17 & $100.0 \%$ & 8 & $100.0 \%$ & 25 & $100.0 \%$ & 25 & $100.0 \%$ \\
\hline
\end{tabular}


Of the program patients, $16.9 \%$ had spent time in a penitentiary, whereas $36.0 \%$ of the non-program patients had been in a penitentiary. The average time spent in such a facility for non-program patients was 33.4 months. The program patients did not respond to the question referring to length of time spent in a penitentiary.

Regarding current charges, one (4.0\%) of the program patients and three (12.0\%) of the non-program patients had such charges. All current charges were intoxication related charges (see Appendix D., Table L).

\section{Alcohol Background}

Almost all patients in this study believed they had a drinking problem. There were $92.0 \%$ of the program patients and $96.0 \%$ of the non-program patients who answered affirmative Iy to having an alcohol problem.

The complete results are in Table XI.

For both categories of patients, the largest percentage of people started drinking between the ages of 13-16 (48.0\% for program patients and $44.0 \%$ for non-program patients). All patients had started drinking before the age of 20 (see Appendix D., Table LI).

Beverages which were used for the first drinking experience varied from beer to hard liquor for program males and non-program males. Program females had used only beer or wine.

The amount of beverage first consumed varied consider- 
TABLE XI

PATIENTS WHO BELIVE THEY HAVE A DRINKING PROBLEM

\begin{tabular}{|c|c|c|c|c|c|c|c|c|}
\hline \multirow{2}{*}{$\begin{array}{l}\text { Drinking } \\
\text { Problem }\end{array}$} & \multicolumn{2}{|c|}{ Program Males } & \multicolumn{2}{|c|}{ Program Females } & \multicolumn{2}{|c|}{ Sub-Total } & \multicolumn{2}{|c|}{ Non-Program Males } \\
\hline & $\begin{array}{c}\text { Freq. of } \\
\text { response }\end{array}$ & Percent & $\begin{array}{l}\begin{array}{l}\text { Freq. of } \\
\text { response }\end{array} \\
\end{array}$ & Percent & $\begin{array}{l}\text { Freq. of } \\
\text { response }\end{array}$ & Percent & $\begin{array}{l}\text { Freq. of } \\
\text { response }\end{array}$ & Percent \\
\hline Yes & 16 & $94.1 \%$ & 7 & $87.5 \%$ & 23 & $92.0 \%$ & 24 & $96.0 \%$ \\
\hline No & 1 & $5.8 \%$ & 1 & $12.5 \%$ & 2 & $8.0 \%$ & 1 & $4.0 \%$ \\
\hline Total & 17 & $99.9 \% *$ & 8 & $100.0 \%$ & 25 & $100.0 \%$ & 25 & $100.0 \%$ \\
\hline
\end{tabular}

* Does not equal $100.0 \%$ due to rounding error. 
ably $y_{i}$ from one glass to three cases of alcohol beverage. Program females had consumed less quantities with a variation of one glass to six glasses of alcohol beverage.

For program patients and non-program patients, $40.0 \%$ had their first drinking experience with friends and $24.0 \%$ with relatives. Only $8.0 \%$ of both groups had drunk alone (see Appendix D., Table LII).

Forty percent of the program patients and $52.0 \%$ of the non-program patients stated that they became drunk during their first drinking experience. Comparing program males and females, $35.3 \%$ of the males felt that they became drunk, while $50.0 \%$ of the females stated they became drunk. Table XII provides the results.

No patients reported any special circumstances revolving around their first drinking experience. However, all patients were able to recall at least certain aspects of their drinking experience.

Due to difficulty in interpreting the results regarding the point when patients believed their drinking had become a problem, the data cannot be presented.

Looking at drinking patterns of patients before entering the hospital, there were $56.0 \%$ of the program patients who usually drank with others, while $52.0 \%$ of the nonprogram patients drank alone. Program males and females differed on this question with $35.0 \%$ of the males drinking alone and no females who preferred to drink alone. Table XIII shows the results. 
TABLE XII

REACTION TO FIRST DRINKING EXPERIENCE

\begin{tabular}{|c|c|c|c|c|c|c|c|c|}
\hline \multirow[b]{2}{*}{ Reaction } & \multicolumn{2}{|c|}{ Program Males } & \multirow{2}{*}{$\begin{array}{l}\text { Program } \\
\text { Freq. of } \\
\text { response }\end{array}$} & \multirow{2}{*}{$\begin{array}{l}\text { Females } \\
\text { Percent }\end{array}$} & \multicolumn{2}{|c|}{ Sub-Total } & \multicolumn{2}{|c|}{ Non-Program Males } \\
\hline & $\begin{array}{l}\text { Freq. of } \\
\text { response }\end{array}$ & Percent & & & $\begin{array}{l}\text { Freq. of } \\
\text { response }\end{array}$ & Percent & $\begin{array}{l}\text { Freq. of } \\
\text { response }\end{array}$ & \begin{tabular}{|l|} 
Percent \\
\end{tabular} \\
\hline Felt good & 3 & $17.6 \%$ & 2 & $25.0 \%$ & 5 & $20.0 \%$ & 6 & $24.0 \%$ \\
\hline Drunk & 6 & $35.3 \%$ & 4 & $50.0 \%$ & 10 & $40.0 \%$ & 13 & $52.0 \%$ \\
\hline Passed out & 2 & $11.7 \%$ & 0 & $0.0 \%$ & 2 & $8.0 \%$ & 1 & $4.0 \%$ \\
\hline No answer & 6 & $35.3 \%$ & 2 & $25.0 \%$ & 8 & $32.0 \%$ & 5 & $20.0 \%$ \\
\hline Total & 17. & $99.9 \%^{*}$ & 8 & $100.0 \%$ & 25 & $100.0 \%$ & 25 & $100.0 \%$ \\
\hline
\end{tabular}

* Does not equal $100.0 \%$ due to rounding error. 
TABLE XIII

STYLE OF DRINKING

\begin{tabular}{|c|c|c|c|c|c|c|c|c|}
\hline \multirow{2}{*}{$\begin{array}{l}\text { How you } \\
\text { Usually } \\
\text { Drink }\end{array}$} & \multicolumn{2}{|c|}{ Program Males } & \multicolumn{2}{|c|}{ Program Females } & \multicolumn{2}{|c|}{ Sub-Tota1 } & \multicolumn{2}{|c|}{ Non-Program Males } \\
\hline & $\begin{array}{l}\text { Freq. of } \\
\text { response }\end{array}$ & Percent & $\begin{array}{l}\text { Freq. of } \\
\text { response }\end{array}$ & Percent & $\begin{array}{l}\text { Freq. of } \\
\text { response }\end{array}$ & Percent & $\begin{array}{l}\text { Freq. of } \\
\text { response }\end{array}$ & Percent \\
\hline Alone & 6 & $35.3 \%$ & 0 & $0.0 \%$ & 6 & $24.0 \%$ & 13 & $52.0 \%$ \\
\hline With others & 8 & $47.0 \%$ & 6 & $75.0 \%$ & 14 & $56.0 \%$ & 7 & $28.0 \%$ \\
\hline $\begin{array}{l}\text { Both alone } \\
\text { \& w/others }\end{array}$ & 3 & $17.6 \%$ & 1 & $12.5 \%$ & 4 & $16.0 \%$ & 5 & $20.0 \%$ \\
\hline No answer & 0 & $0.0 \%$ & 1 & $12.5 \%$ & 1 & $4.0 \%$ & 0 & $0.0 \%$ \\
\hline Total & 17 & $99.9 \%$ & 8 & $100.0 \%$ & 25 & $100.0 \%$ & 25 & $100.0 \%$ \\
\hline
\end{tabular}

* Does not equal $100.0 \%$ due to rounding error 
Most patients (64.0\% for both groups) preferred to drink in several places such as their home, bar, with friends, etc., rather than frequenting one specific locality to drink (see Appendix D., Table LIII).

There were $40.0 \%$ of the program patients and $36.0 \%$ of the non-program patients who drank more than 2 quarts of wine a day before coming into the hospital. All other patients drank less amounts and the percentages were spread

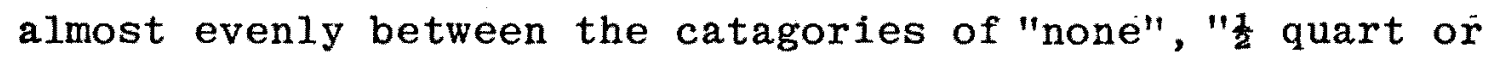
less", "one quart", and "two quarts" (see Appendix D., Table LIV).

Forty percent of the program patients and $36.0 \%$ of the non-program patients drank more than three quarts of beer daily. Percentages were less for all other smaller quantities of consumption (see Appendix D., Table LV).

There were $44.0 \%$ of the program patients and $28.0 \%$ of non-program patients who stated that they didn't drink hard liquor at all. Of the program males, $58.0 \%$ didn't drink hard liquor compared with $12.5 \%$ of program females. For program patients and non-program patients, $29.9 \%$ drank more than onequart. All other patients were in the categories between "none" and "more than one quart" (see Appendix D., Table LVI). Almost all patients indicated that they had not consumed any alcohol substitutes such as shaving lotion, hair tonic, or cough syrup. Table XIV shows the results below. There were $36.0 \%$ of the program patients who felt they had been able to stop drinking by themselves compared with 
TABLE XIV

ALCOHOL SUBSTITUTES CONSUMED

\begin{tabular}{|c|c|c|c|c|c|c|c|c|}
\hline \multirow{2}{*}{$\begin{array}{l}\text { Amounts of } \\
\text { Substitutes }\end{array}$} & \multicolumn{2}{|c|}{ Program Males } & \multicolumn{2}{|c|}{ Program Females } & \multicolumn{2}{|c|}{ Sub-Total } & \multicolumn{2}{|c|}{ Non-Program Males } \\
\hline & $\begin{array}{l}\text { Freq. of } \\
\text { response }\end{array}$ & Percent & $\begin{array}{l}\text { Freq. of } \\
\text { response }\end{array}$ & Percent & $\begin{array}{l}\text { Freq. of } \\
\text { response }\end{array}$ & Percen & $\begin{array}{l}\text { Freq. of } \\
\text { response }\end{array}$ & Percent \\
\hline None & 14 & $82.3 \%$ & 6 & $75.0 \%$ & 20 & $80.0 \%$ & 23 & $92.0 \%$ \\
\hline Pint & 0 & $0.0 \%$ & 0 & $0.0 \%$ & 0 & $0.0 \%$ & 2 & $8.0 \%$ \\
\hline No answer & 3 & $17.6 \%$ & 2 & $25.0 \%$ & 5 & $20.0 \%$ & 0 & $0.0 \%$ \\
\hline Total & 17 & $99.9 \%$ & 8 & $100.0 \%$ & 25 & $100.0 \%$ & 25 & $100.0 \%$ \\
\hline
\end{tabular}

* Does not equal $100.0 \%$ due to rounding error. 
$48.0 \%$ of the non-program patients. Of the program patients, $47.0 \%$ of the males were able to stop drinking on their own, while only $12.5 \%$ of the females said the same. Those program patients who believed they could not stop by themselves encompassed $56.0 \%$ of the patients in contrast to $48.0 \%$ of the non-program patients. Table XV provides the results.

Regarding binge or continuous drinking patterns, $52.9 \%$ of program males and $12.5 \%$ of program females (a total of $40.0 \%$ of program patients) believed they were binge drinkers contrasted with $28.0 \%$ of the non-programpatients. There were $47.0 \%$ of the program males and $87.5 \%$ of the program females (a total of $60.0 \%$ of program patients) who felt they were continuous drinkers compared with $72.0 \%$ of the non-program patients. Table XVI shows the complete results.

of the nine program males who felt they were binge drinkers (drinking for several days, then remaining sober for several days), 4 patients said they would drink several days in a row, sober up for a period of time, and then begin drinking again. Tho patients followed this pattern sometimes and 3 patients didn't answer the question. The 1 female stated that she didn't follow this pattern. There were 2 non-program patients who usually followed the above pattern and five who sometimes drank in this pattern.

The number of days of continuous drinking in the above pattern for program males ranged from 2-14 days, 1 day for the program female, and 2-33 days for the non-program patients. 


\section{TABLE XV}

PATIENTS WHO HAVE THE ABILITY TO STOP DRINKING

\begin{tabular}{|c|c|c|c|c|c|c|c|c|}
\hline \multirow{2}{*}{$\begin{array}{l}\text { Ability to } \\
\text { Stop }\end{array}$} & \multicolumn{2}{|c|}{ Program Males } & \multicolumn{2}{|c|}{ Program Females } & \multicolumn{2}{|c|}{ Sub-Total } & \multicolumn{2}{|c|}{ Non-Program Males } \\
\hline & $\begin{array}{l}\text { Freq. of } \\
\text { response }\end{array}$ & Percen & $\begin{array}{l}\text { req. of } \\
\text { response }\end{array}$ & Percent & $\begin{array}{l}\text { Freq. of } \\
\text { response }\end{array}$ & Percent & $\begin{array}{l}\text { Freq. of } \\
\text { response }\end{array}$ & Percent \\
\hline Yes & 8 & $47.0 \%$ & 1 & $12.5 \%$ & 9 & $36.0 \%$ & 12 & $48.0 \%$ \\
\hline No & 8 & $47.0 \%$ & 6 & $75.0 \%$ & 14 & $56.0 \%$ & 12 & $48.0 \%$ \\
\hline Other & $1^{*}$ & $5,8 \%$ & 0 & $0.0 \%$ & 1 & $4.0 \%$ & $1^{* * *}$ & $4.0 \%$ \\
\hline No answer & 0 & $0.0 \%$ & 1 & $12.5 \%$ & 1 & $4.0 \%$ & 0 & $0.0 \%$ \\
\hline Total & 17 & $99.8 \%$ & $*$ & $100.0 \%$ & 25 & $100.0 \%$ & 25 & $100.0 \%$ \\
\hline
\end{tabular}

* "Occasionally when anxious or depressed"

** Does not equal $100.0 \%$ due to rounding error.

***"Yes and no" 
TABLE XVI

DRINKING PATTERN BEFORE ENTERING THE HOSPITAL

\begin{tabular}{|c|c|c|c|c|c|c|c|c|}
\hline \multirow{2}{*}{$\begin{array}{l}\text { Drinking } \\
\text { Pattern }\end{array}$} & \multicolumn{2}{|c|}{ Program Males } & \multicolumn{2}{|c|}{ Program Females } & \multicolumn{2}{|c|}{ Sub-Total } & \multicolumn{2}{|c|}{ Non-Program Males } \\
\hline & $\begin{array}{l}\text { Freq. of } \\
\text { response }\end{array}$ & Percent & $\begin{array}{l}\text { Freq. of } \\
\text { response } \\
\end{array}$ & Percent & $\begin{array}{l}\text { Freq. of } \\
\text { response }\end{array}$ & Percent & $\begin{array}{l}\text { Freq. of } \\
\text { response }\end{array}$ & Percent \\
\hline Binge Drinking & 9 & $52.9 \%$ & 1 & $12.5 \%$ & 10 & $40.0 \%$ & 7 & $28.0 \%$ \\
\hline Cont. Drinking & 8 & $47.0 \%$ & 7 & $87.5 \%$ & 15 & $60.0 \%$ & 18 & $72.0 \%$ \\
\hline pther & 0 & $0.0 \%$ & 0 & $.0 .0 \%$ & 0 & $0.0 \%$ & 0 & $0.0 \%$ \\
\hline Total & 17 & $99.9 \%^{*}$ & 8 & $100.0 \%$ & 25 & $100.0 \%$ & 25 & $100.0 \%$ \\
\hline
\end{tabular}

* Does not equal $100.0 \%$ due to rounding error 
The number of days between drinking binges (sober days) for program males ranged from 1 day to 6 months, 2-10 days for the one program female, and 2 days to 2 months for the non-program males.

There were 4 program males, the 1 program female, and 3 non-program males who stopped drinking completely between drinking binges. One program male and 3 non-program males tapered off, and 1 program male and 1 non-program male stated that they had not been able to stop at all recently. Three program males didn't provide an answer (regarding question 46 of the questionnaire).

Patients were asked next to restate their periods of sobriety ( $t$ ime when they didn't drink at all) into one of the following categories: 1) "less than a week", 2) "up to a month", or 3) "more than a month". Four program males, the 1 female, and three non-program patients stated "up to a month". One program male and 2 non-program males stated "more than a month". Three program males didn't answer the question and 1 non-program male stated all three categories.

Table XVII provides the number of people who were intoxicated when entering Dammasch State Hospital.

There were $44.0 \%$ of the program patients and non-program patients who were intoxicated when they were admitted into the hospital.

Regarding loss of employment, $64.0 \%$ of the program patients and $76.0 \%$ of the non-program patients had lost jobs 
TABLE XVII

PATIENTS WHO WERE INTOXICATED WHEN ADMITTED INTO THE HOSPITAL

\begin{tabular}{|c|c|c|c|c|c|c|c|c|}
\hline \multirow{2}{*}{ Intoxicated } & \multicolumn{2}{|c|}{ Program Males } & \multicolumn{2}{|c|}{ Program Females } & \multicolumn{2}{|c|}{ Sub-Total } & \multicolumn{2}{|c|}{ Non-Program Males } \\
\hline & \begin{tabular}{|l|} 
Freq. of \\
response
\end{tabular} & Percen & $\begin{array}{l}\text { Freq. of } \\
\text { tresponse }\end{array}$ & Percent & $\begin{array}{l}\text { Freq. of } \\
\text { response }\end{array}$ & Percent & $\begin{array}{l}\text { req. of } \\
\text { response }\end{array}$ & Percent \\
\hline Yes & 8 & $47.0 \&$ & 3 & $37.5 \%$ & 11 & $44.0 \%$ & 11. & $44.0 \%$ \\
\hline No & 8 & $47.0 \%$ & 4 & $50.0 \%$ & 12 & $48.0 \%$ & 14 & $56.0 \%$ \\
\hline No answer & 1 & $5.8 \%$ & 1 & $12.5 \%$ & 2 & $8.0 \%$ & 0 & $0.0 \%$ \\
\hline Total & 17 & $99.8 \% *$ & 8 & $100.0 \%$ & 25 & $100.0 \%$ & 25 & $100.0 \%$ \\
\hline
\end{tabular}

*Does not equal $100.0 \%$ due to rounding error. 
either through quitting or being fired as a direct result from drinking. Comparing program males with program females, 76.5\% of the males had lost jobs in contrast to $37.5 \%$ of the females (see Appendix D., Table LVII).

The number of jobs that were lost ranged from 1-10 jobs for program males, 1-3 jobs for program females, and 1-12 jobs for non-program patients.

Patients were asked to rate several items as reasons for drinking. There were $40.0 \%$ of the program patients and $48.0 \%$ of the non-program patients who felt that relaxation was a very important reason for drinking and $32.0 \%$ of the program patients and $36.9 \%$ of the non-program patients thought the effects of relaxation were fairly important (see Appendix D., Table LVIII).

Regarding drinking in order to be sociable, $48.0 \%$ of the program patients rated sociability as either very important or fairly important compared with $60.0 \%$ for non-program patients. There were $32.0 \%$ of the program patients who felt that sociability was not an important reason for their. drinking behavior contrasted with $20.0 \%$ of the non-program patients (see Appendix D., Table LVIX).

There were $64.0 \%$ of the program patients who believed that drinking in order to forget unpleasant thoughts was very or fairly important, while $88.0 \%$ of the non-program patients drank to relieve unpleasant thoughts (see Appendix D., Table $L X)$.

Most patients believed they drank in order to feel less 
depressed and anxious. Of the program males, $76.0 \%$ rated depression and anxiety as either very or fairly important. There were $29.4 \%$ of the program males and $87.5 \%$ of the program females who rated depression and anxiety as very important (for a total of $48.0 \%$ of all program patients). There were $41.1 \%$ of the males who stated that the above reason for drinking was fairly important compared to none of the program females. For non-program males, $80.0 \%$ stated that depression and anxiety were either very or fairly important as reasons for drinking (see Appendix D., Table LXI).

Twenty-eight percent of the program patients and $16.0 \%$ of the non-program patients believed that drinking to relieve angry feelings was very important to them. There were $16.0 \%$ of the program patients and $32.0 \%$ of the non-program patients who felt that drinking to relieve angry feelings was fairly important. All other patients either didn't answer or believed that relief of angry feelings through drinking was not at all important to them (see Appendix D., Table LXII) .

There were $20.0 \%$ of program patients and non-program patients who believed that drinking was very important in order to relate feelings and thoughts to the opposite sex. Twenty-three percent of the program males, $62.5 \%$ of the program females, and $28.0 \%$ of the non-program patients didn't answer the question (see Appendix D., Table LXIII).

Over half of the patients believed that changing their moods was either a very or fairly important reason for drink- 
ing $(64: 0 \%$ of the program patients and $72.0 \%$ of the non-program patients). There were $16.0 \%$ of both groups of patients who felt that the changing of mood was not at all important as a reason for drinking (see Appendix D., Table LXIV).

When asked whether they tended to shut out the world when drinking, $24.0 \%$ of the program patients and $16.0 \%$ of the non-program patients indicated that this usually happened to them. There were $32.0 \%$ of the program patients and $48.0 \%$ of the non-program patients who felt that they shut out their world occasionally while drinking (see Appendix D., Table LXV).

Table XVIII shows the percentage of patients who felt guilty about their drinking.

As Table XVIII illustrates, $48.0 \%$ of the program patients and $56.0 \%$ of the non-program patients usualiy felt guilty about their drinking. There was considerable differences between program males and females in response to this topic. There were $70.6 \%$ of the males who indicated usually feeling guilty compared with none of the females. There were $50.0 \%$ of the females who said they never felt guilty about their drinking contrasted with $5.8 \%$ of the males.

Over half of the patients felt that they didn't express anger or start fights when they drank. One (4.0\%) of the program patients and two $(8.0 \%)$ of the non-program patients stated that they usually expressed anger or started fights when drinking. There were $48.0 \%$ of both groups of patients who said they never became angry or started fights. Table XIX 
TABLE XVIII

PATIENTS WHO FEEL GUILTY ABOUT THEIR DRINKING

\begin{tabular}{|c|c|c|c|c|c|c|c|c|}
\hline \multirow{2}{*}{$\begin{array}{l}\text { Feel } \\
\text { Guilty }\end{array}$} & \multicolumn{2}{|c|}{ Program Males } & \multicolumn{2}{|c|}{ Program Females } & \multicolumn{2}{|c|}{ Sub-Total } & \multicolumn{2}{|c|}{ Non-Program Males } \\
\hline & $\begin{array}{l}\text { Freq. of } \\
\text { response }\end{array}$ & Percent & $\begin{array}{l}\text { Freq. of } \\
\text { response }\end{array}$ & Percent & $\begin{array}{l}\text { Freq. of } \\
\text { response }\end{array}$ & Percent & $\begin{array}{l}\text { Freq. of } \\
\text { response }\end{array}$ & Percent \\
\hline Yes, usually & 12 & $70.6 \%$ & 0 & $0.0 \%$ & 12 & $48.0 \%$ & 14 & $56.0 \%$ \\
\hline Yes.sometimes & 3 & $17.6 \%$ & 3 & $37.5 \%$ & 6 & $24.0 \%$ & 10 & $40.0 \%$ \\
\hline No & 1 & $5.8 \%$ & 4 & $50.0 \%$ & 5 & $20.0 \%$ & 1 & $4.0 \%$ \\
\hline No answer & 1 & $5.8 \%$ & 1 & $12.5 \%$ & 2 & $8.0 \%$ & 0 & $0.0 \%$ \\
\hline Total & 17. & $99.8 \%^{*}$ & 8 & $100.0 \%$ & 25 & $100.0 \%$ & 25 & $100.0 \%$ \\
\hline
\end{tabular}

* Does not equal $100.0 \%$ due to rounding error. 
TABLE XIX

PATIENTS WHO EXPRESS ANGER OR START FIGHTS WHEN DRINKING

\begin{tabular}{|c|c|c|c|c|c|c|c|c|}
\hline & \multicolumn{2}{|c|}{ Program Males } & \multicolumn{2}{|c|}{ Program Females } & \multicolumn{2}{|c|}{ Sub-Total } & \multicolumn{2}{|c|}{ Non-Program Males } \\
\hline & $\begin{array}{l}\text { Freq. of } \\
\text { cesponse }\end{array}$ & Percent & $\begin{array}{l}\text { Freq. of } \\
\text { response }\end{array}$ & Percent & $\begin{array}{c}\text { Freq. of } \\
\text { response }\end{array}$ & Percent & $\begin{array}{l}\text { Freq. of } \\
\text { cesponse }\end{array}$ & Percent \\
\hline Yes, usually & 1 & $5.8 \%$ & 0 & $0.0 \%$ & 1 & $4.0 \%$ & 2 & $8.0 \%$ \\
\hline Yes, sometimes & 6 & $35.3 \%$ & 4 & $50.0 \%$ & 10 & $40.0 \%$ & 11 & $44.0 \%$ \\
\hline No & 9 & $52.9 \%$ & 3 & $37.5 \%$ & 12 & $48.0 \%$ & 12 & $48.0 \%$ \\
\hline No answer & 1 & $5.8 \%$ & 1 & $12.5 \%$ & 2 & $8.0 \%$ & 0 & $0.0 \%$ \\
\hline Total & 17 & $99.8 \% *$ & 8 & $100.0 \%$ & 25 & $100.0 \%$ & 25 & $100.0 \%$ \\
\hline
\end{tabular}

* Does not equal $100.0 \%$ due to rounding error. 
shows the results.

For both groups of patients, $60.0 \%$ had never attempted suicide when drinking. There were $16.0 \%$ of the program males and $25.0 \%$ of the non-program patients who had attempted suicide once. On1y $8.0 \%$ of the program patients and $4.0 \%$ of the non-program patients had attempted suicide several times (see Appendix D., Table LXVI).

Over half of the patients felt their drinking had caused hardships for their families and/or friends. There were $68.0 \%$ of the program patients and $64.0 \%$ of the non-program patients who felt they had caused hardships (see Appendix D., Table LXVII).

Fifty-two percent of the program patients indicated a near relative had sought professional help about their drinking. Fifty-six percent of the non-program patients had never had a near relative who had sought help. Table XX provides the results.

There were $60.0 \%$ of the program patients who stated that they were not currently experiencing; any family disruption (divorce, separation, etc.) due to drinking compared with $56.0 \%$ of the non-program patients who indicated that they were experiencing family disruption. Table XXI illustrates.

Fifty-six percent of the program patients and $52.0 \%$ of non-program patients indicated that there was a history of drinking problems in their families. The relatives most frequently mentioned were parents and siblings (see Appendix 
TABLE XX

PROFESSIONAL HELP SOUGHT BY FAMILIES

\begin{tabular}{|c|c|c|c|c|c|c|c|c|}
\hline & \multicolumn{2}{|c|}{ Program Males } & \multicolumn{2}{|c|}{ Program Females } & \multicolumn{2}{|c|}{ Sub-Total } & \multicolumn{2}{|c|}{ Non-Program Males } \\
\hline & $\begin{array}{l}\text { Freq. of } \\
\text { Response }\end{array}$ & Percent & freq. of & Percent & $\begin{array}{l}\text { Feq. of } \\
\text { response }\end{array}$ & Percent & $\begin{array}{l}\text { Freq. of } \\
\text { response }\end{array}$ & Percent \\
\hline Yes & 8 & $47.0 \%$ & 5 & $62.5 \%$ & 13 & $52.0 \%$ & 11 & $44.0 \%$ \\
\hline No & 8 & $47.0 \%$ & 3 & $37 . \% \%$ & 11 & $44.0 \%$ & 14 & $56.0 \%$ \\
\hline No answer & 1 & $5.8 \%$ & 0 & $0.0 \%$ & 1 & $4.0 \%$ & 0 & $0.0 \%$ \\
\hline Total & 17 & $99.8 \%^{*}$ & 8 & $100.0 \%$ & 25 & $100.0 \%$ & 25 & $100.0 \%$ \\
\hline
\end{tabular}

* Does not equal $100.0 \%$ due to rounding error. 
TABLE XXI

PATIENTS EXPERIENCING FAMILY DISRUPTION DUE TO DRINKING

\begin{tabular}{|c|c|c|c|c|c|c|c|c|}
\hline & \multicolumn{2}{|c|}{ Program Males } & \multicolumn{2}{|c|}{ Program Females } & \multicolumn{2}{|c|}{ Sub-Total } & \multicolumn{2}{|c|}{ Non-Program Males } \\
\hline & $\begin{array}{l}\text { Freq. of } \\
\text { response }\end{array}$ & Percent & $\begin{array}{l}\text { Freq. of } \\
\text { response }\end{array}$ & Percent & $\begin{array}{l}\text { Freq. of } \\
\text { response }\end{array}$ & Percent & $\begin{array}{l}\text { Freq: of } \\
\text { response }\end{array}$ & Percent \\
\hline Yes & 4 & $23.5 \%$ & 3 & $37.5 \%$ & 7 & $28.0 \%$ & 14 & $56.0 \%$ \\
\hline No & 12 & $70.6 \%$ & 3 & $37.5 \%$ & 15 & $60.0 \%$ & 10 & $40.0 \%$ \\
\hline No answer & 1 & $5.8 \%$ & 2 & $25.0 \%$ & 3 & $12.0 \%$ & 1 & $4.0 \%$ \\
\hline Total & 17 & $99.9 \%^{*}$ & 8 & $100.0 \%$ & 15 & $100.0 \%$ & 15 & $100.0 \%$ \\
\hline
\end{tabular}

* Does not equal $100.0 \%$ due to rounding error. 
D., Table LXVIII).

Table XXII provides information on the percentage of patients who wanted to stop drinking completely.

There were $80.0 \%$ of the program patients and $72.0 \%$ of the non-program patients who indicated a desire to stop drinking completely.

Most patients $(75.0 \%$ of program patients and $60.0 \%$ of non-program patients) believed their living situation would be very important in their treatment of alcohol abuse. Table XXIII illustrates this belief.

Changing associates as part of the treatment was very important to $52.0 \%$ of the program patients and to $36.0 \%$ of the non-program patients (see Appendix D., Table LXIX). Group therapy was considered to be very important to $56.0 \%$ of the program patients and $32.0 \%$ of the non-program patients (see Appendix D., Table LXX). Alcoholics Anonymous was very or fairly important to $56.0 \%$ of the program patients and $52.0 \%$ of the non-program patients (see Appendix D., Table LXXI). Individual therapy as part of treatment was considered very important to $52.0 \%$ of the program patients and $28.0 \%$ of the non-program patients (see Appendix D., Table LXXII).

Education on the effects of Alcohol was very important to $36.0 \%$ of the program patients and $24.0 \%$ of the non-program patients. It was fairly important to $16.0 \%$ of the program patients and $28.0 \%$ of the non-program patients (see Appendix D., Table LXXIII). 
TABLE XXII

PATIENTS WHO WANT TO STOP DRINKING COMPLETELY

\begin{tabular}{|c|c|c|c|c|c|c|c|c|}
\hline & \multicolumn{2}{|c|}{ Program Males } & \multicolumn{2}{|c|}{ Program Females } & \multicolumn{2}{|c|}{ Sub-Total } & \multicolumn{2}{|c|}{ Non-Program Males } \\
\hline & $\begin{array}{l}\text { Freq. of } \\
\text { response }\end{array}$ & Percent & $\begin{array}{l}\text { Freq.of } \\
\text { response }\end{array}$ & Percent & $\begin{array}{l}\text { Freq.of } \\
\text { responce }\end{array}$ & Percent & $\begin{array}{l}\text { Freq. of } \\
\text { response }\end{array}$ & Percent \\
\hline Yes & 15 & $88.2 \%$ & 5 & $62.5 \%$ & 20 & $80.0 \%$ & 18 & $72.0 \%$ \\
\hline No & 1 & $5.8 \%$ & 2 & $25.0 \%$ & 3 & $12.0 \%$ & 4 & $16.0 \%$ \\
\hline No answer & 1 & $5.8 \%$ & 1 & $12.5 \%$ & 2 & $8.0 \%$ & 3 & $12.0 \%$ \\
\hline Total & 17 & $99.8 \%^{*}$ & 8 & $100.0 \%$ & 25 & $100.0 \%$ & 25 & $100.0 \%$ \\
\hline
\end{tabular}

* Does not equal $100.0 \%$ due to rounding error. 
TABLE XXIII

CHANGE IN LIVING SITUATION

\begin{tabular}{|c|c|c|c|c|c|c|c|c|}
\hline \multirow{2}{*}{$\begin{array}{l}\text { Level of } \\
\text { Importance }\end{array}$} & \multicolumn{2}{|c|}{ Program Males } & \multicolumn{2}{|c|}{ Program Females } & \multicolumn{2}{|c|}{ Sub-TotaI } & \multicolumn{2}{|c|}{ Non-Program Males } \\
\hline & Freq. of & & req.ot & Percent & $\begin{array}{l}\text { Freq. of } \\
\text { response }\end{array}$ & Percent & $\begin{array}{l}\text { Freq.of } \\
\text { response }\end{array}$ & Percent \\
\hline $\begin{array}{l}\text { Very } \\
\text { Important }\end{array}$ & 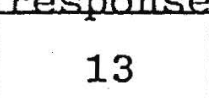 & $76.5 \%$ & Cespunse & $75.0 \%$ & 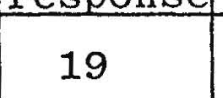 & $76.0 \%$ & $\mu^{2}=0$ & $60.0 \%$ \\
\hline $\begin{array}{l}\text { Fairly } \\
\text { Important }\end{array}$ & 1 & $5.8 \%$ & 0 & $0.0 \%$ & 1 & $4.0 \%$ & 3 & $12.0 \%$ \\
\hline $\begin{array}{l}\text { Not at all } \\
\text { Important }\end{array}$ & 3 & $17.6 \%$ & 1 & $12.5 \%$ & 4 & $16.0 \%$ & 4 & $16.0 \%$ \\
\hline No answer & 0 & $0.0 \%$ & 1 & $12.5 \%$ & 1 & $4.0 \%$ & 4 & $16.0 \%$ \\
\hline Total & 17 & $99.9 \% *$ & 8 & $100.0 \%$ & 25 & $100.0 \%$ & 25 & $100.0 \%$ \\
\hline
\end{tabular}

* Does not equal $100.0 \%$ due to rounding error. 
One non-program patient offered the answer of "antabuse" as being a very important form of treatment.

\section{Medical/Psychological History}

There were $36.0 \%$ of the program patients who had previous hospitalizations for alcohol abuse compared with $72.0 \%$ of the non-program patients. Table XXIV provides the results.

The number of previous hospitalizations ranged from 1-13 times for program patients and 1-26 times for non-program patients.

Locations of hospitalizations for program patients included Dammasch State Hospital, Multnomah County Hospital, Woodland Park Hospital, and Portland Detox. Locations of previous hospitalizations for the non-program patients were more varied and included the Community Hospitals in Anchorage and Fairbanks, Alaska, Providence Hospital in Seattle, Washington, Detox in Anchorage, Alaska, Dammasch State Hospital, Holiday Park Hospital, Raliegh Hills, Portland Detox, and Providence Hospital in Portland, and hospitals in Chicago, Illinois.

Dates for hospitalizations for the program patients ranged from 1953-1976 and 1962-1976 for non-program patients.

Thirty-two of the program patients and $28.0 \%$ of the non-program patients had previous community treatment of alcohol abuse (such as a mental health clinic or alcohol treatment center).

Location of community treatment for the program 
TABLE XXIV

PREVIOUS HOSPITALIZATIONS FOR ALCOHOL ABUSE

\begin{tabular}{|c|c|c|c|c|c|c|c|c|}
\hline & \multicolumn{2}{|c|}{ Program Males } & \multicolumn{2}{|c|}{ Program Females } & \multicolumn{2}{|c|}{ Sub-Total } & \multicolumn{2}{|c|}{ Non-Program Males } \\
\hline & $\begin{array}{l}\text { Freq. of } \\
\text { response }\end{array}$ & Percent & $\begin{array}{l}\text { Freq. of } \\
\text { response }\end{array}$ & Percent & $\begin{array}{l}\text { Freq of } \\
\text { response }\end{array}$ & Percent & $\begin{array}{l}\text { Freq of } \\
\text { response }\end{array}$ & Percent \\
\hline Yes & 6 & $35.3 \%$ & 3 & $37.5 \%$ & 9 & $36.0 \%$ & 18 & $72.0 \%$ \\
\hline No & 9 & $52.9 \%$ & 5 & $62.5 \%$ & 14 & $56.0 \%$ & 7 & $28.0 \%$ \\
\hline No answer & 2 & $11.7 \%$ & 0 & $0.0 \%$ & 2 & $8.0 \%$ & 0 & $0.0 \%$ \\
\hline Total & 17 & $99.9 \% *$ & 8 & $100.0 \%$ & 25 & $100.0 \%$ & 25 & $100.0 \%$ \\
\hline
\end{tabular}

* Does not equal $100.0 \%$ due to rounding error. 
patients included the Oregon Mental Health Alcohol Treatment and Training Center, Alcoholics Anonymous, and Multnomah County Mental Health. Location of such treatment for the non-program patients included the Portland Kaiser Mental Health Clinic, the Oregon Mental Health Alcohol Treatment and Training Center, and the Seattle Mental Health Clinics (see Appendix D., Table LXXIV). Regarding level of health, $16.0 \%$ of the program patients felt their health was excellent compared with $40.0 \%$ of the non-program patients. Table XXV provides further details.

There were $20.0 \%$ of the program patients and $16.0 \%$ of the non-program patients who believed their health was better now than a year ago, and there were $44.0 \%$ of the program patients and $40.0 \%$ of the non-program patients who felt their health was worse now (see Appendix D., Table LXXV).

Table XXVI provides data on patients who have had any major medical of psychiatric problems treated.

There were $40.0 \%$ of the program males who had major medical or psychiatric treatment compared with $16.0 \%$ of the non-program patients.

Locations of medical or psychiatric treatment for the program patients included Gresham General, Dammasch State Hospital, Woodland Park Hospital, and South Dakota State Hospital .

Locations of medical of psychiatric treatment for 
TABLE XXV

LEVEL OF HEALTH

\begin{tabular}{|c|c|c|c|c|c|c|c|c|}
\hline \multirow{2}{*}{$\begin{array}{l}\text { Level of } \\
\text { Health }\end{array}$} & \multicolumn{2}{|c|}{ Program Males } & \multicolumn{2}{|c|}{ Program Females } & \multicolumn{2}{|c|}{ Sub-Total } & \multicolumn{2}{|c|}{ Non-Program Males } \\
\hline & $\begin{array}{l}\text { Freq. of } \\
\text { response }\end{array}$ & Percent & $\begin{array}{l}\text { Freq. of } \\
\text { response }\end{array}$ & Percent & $\begin{array}{l}\text { Freq.of } \\
\text { fesponse }\end{array}$ & Percent & $\begin{array}{l}\text { Freq. of } \\
\text { response }\end{array}$ & Percent \\
\hline Excellent & 3 & $17.6 \%$ & 1 & $12.5 \%$ & 4 & $16.0 \%$ & 10 & $40.0 \%$ \\
\hline Good & 9 & $52.9 \%$ & 1 & $12.5 \%$ & 10 & $40.0 \%$ & 6 & $24.0 \%$ \\
\hline Fair & 0 & $0.0 \%$ & 3 & $37.5 \%$ & 3 & $12.0 \%$ & 7 . & $28.0 \%$ \\
\hline Poor & 4 & $23.5 \%$ & 3 & $37.5 \%$ & 7 & $28.0 \%$ & 2 & $8.0 \%$ \\
\hline No answer & 1 & $5.8 \%$ & 0 & $0.0 \%$ & 1 & $4.0 \%$ & 0 & $0.0 \%$ \\
\hline Total & 17 & $99.8 \%^{*}$ & 8 & $100.0 \%$ & 25 & $100.0 \%$ & 25 & $100.0 \%$ \\
\hline
\end{tabular}

* Does not equal $100.0 \%$ due to rounding error. 
TABLE XXVI

MAJOR MEDICAL OR PSYCHIATRIC TREATMENT

\begin{tabular}{|c|c|c|c|c|c|c|c|c|}
\hline & \multicolumn{2}{|c|}{ Program Males } & \multicolumn{2}{|c|}{ Program Females } & \multicolumn{2}{|c|}{ Sub-Total } & \multicolumn{2}{|c|}{ Non-Program Males } \\
\hline & $\begin{array}{l}\text { Freq. of } \\
\text { respense }\end{array}$ & Percent & $\begin{array}{l}\text { Freq. of } \\
\text { response }\end{array}$ & Percent & $\begin{array}{l}\text { Freq. of } \\
\text { response }\end{array}$ & Percen & $\begin{array}{l}\text { Freq. of } \\
\text { response }\end{array}$ & Percent \\
\hline Yes & 4 & $23.5 \%$ & 6 & $75.0 \%$ & 10 & $40.0 \%$ & 4 & $16.0 \%$ \\
\hline No & 11 & $64.7 \%$ & 2 & $25.0 \%$ & 13 & $52.0 \%$ & 18 & $72.0 \%$ \\
\hline No answer & 2 & $11.7 \%$ & 0 & $0.0 \%$ & 2 & $-8.0 \%$ & $3 * * *$ & $120 \%$ \\
\hline Total & 17 & $99.9 \% *$ & 8 & $100.0 \%$ & 25 & $100.0 \%$ & 25 & $100.0 \%$ \\
\hline
\end{tabular}

* Does not equal $100.0 \%$ due to rounding error.

** 2 patients provided no answer

1 patient indicated "none of your business".: 
non-program patients included St. Vincent's Hospital, Holiday Park Hospital, Fitsimmon's Army Hospital (Denver, Colorado), and the U.S. Veteran's Hospital (Portland, Oregon).

The majority of patients $(60.0 \%$ of the program patients and $56.0 \%$ of the non-program patients) had never used narcotics such as heroin, morphine, or speed. Complete results are in Table XXVII.

Twenty-eight percent of the program patients had used antabuse to help them to stop drinking compared with $56.0 \%$ of the non-program patients. None of the program females had used antabuse (see Appendix D., Table LXXVI).

For both groups of patients, $50.0 \%$ who had taken antabuse also drank on it at least once. Reactions to drinking while using antabuse ranged from "no reaction" to almost died".

Most patients were not taking any medication when they took the questionnaire ( $56.0 \%$ for both groups of patients). These patients taking medications usually were prescribed valium, multiple vitamins, dilantin, or antabuse.

Patients had heard of Dammasch State Hospital through a variety of sources. Friends and relatives were most frequently mentioned for both groups of patients, but patients had also been referred through other agencies such as the University of Oregon Medical School, Portland Detox, former patients, and private physicians. 
TABLE XXVII

\section{USE OF HARD NARCOTICS}

\begin{tabular}{|c|c|c|c|c|c|c|c|c|}
\hline \multirow[b]{2}{*}{ Use } & \multicolumn{2}{|c|}{ Program Males } & Program & Females & \multicolumn{2}{|c|}{ Sub-Total } & \multicolumn{2}{|c|}{ Non-Program Males } \\
\hline & $\begin{array}{l}\text { Freq. of } \\
\text { response }\end{array}$ & Percent & $\begin{array}{l}\text { req. of } \\
\text { response }\end{array}$ & Percent & $\begin{array}{l}\text { Freq. of } \\
\text { response }\end{array}$ & Percent & $\begin{array}{l}\text { Freq. of } \\
\text { response }\end{array}$ & Percent \\
\hline Never & 10 & $58.8 \%$ & 5 & $62.5 \%$ & 15 & $60.0 \%$ & 14 & $56.0 \%$ \\
\hline Once or & 3 & $17.6 \%$ & 1 & $12.5 \%$ & 4 & $16.0 \%$ & 2 & $8.0 \%$ \\
\hline Several & 3 & $17.6 \%$ & 2 & $25.0 \%$ & 5 & $20.0 \%$ & 8 & $32.0 \%$ \\
\hline No answer & 1 & $5.8 \%$ & 0 & $0.0 \%$ & 1 & $4.0 \%$ & 1 & $4.0 \%$ \\
\hline Total & 17 & $99.8 \%^{*}$ & 8 & $100.0 \%$ & 25 & $100.0 \%$ & 25 & $100.0 \%$ \\
\hline
\end{tabular}

* Does not equal $100.0 \%$ due to rounding exror. 
Over half of the patients were aware of the Alcohol Treatment Program. Only 16.0\% of the non-program patients had not been informed of the specialized unit. Friends and relatives had most frequently been the source of information. Other sources included the Oregon Mental Health Alcohol Treatment and Training Center, the Alcohol Treatment Program follow-up counselors and other hospital staff, Portland Detox, and private physicians.

Table XXVIII provides data regarding patients' feelings about the Alcohol Treatment Program being located in a state hospital.

There were $36.0 \%$ of the program patients and $44.0 \%$ of the non-program patients who indicated that their preference would have been an alcohol treatment program which was not located in a state hospital. Twenty-three percent of the program males preferred a program outside a state hospital compared with $62.5 \%$ of the program females. 
TABLE XXVIII

PREFERENCE FOR AN ALCOHOL TREATMENT PROGRAM OUTSIDE OF A STATE HOSPITAL

\begin{tabular}{|c|c|c|c|c|c|c|c|c|}
\hline & \multicolumn{2}{|c|}{ Program Males } & \multicolumn{2}{|c|}{ Program Females } & \multicolumn{2}{|c|}{ Sub-Total } & \multicolumn{2}{|c|}{ Non-Program Males } \\
\hline & $\begin{array}{l}\text { Freq. of } \\
\text { response }\end{array}$ & Percent & $\begin{array}{l}\text { Freq.of } \\
\text { response }\end{array}$ & Percent & $\begin{array}{l}\text { Freq. of } \\
\text { fesponse }\end{array}$ & Percent & $\begin{array}{l}\text { Freq. of } \\
\text { response }\end{array}$ & Percent \\
\hline Yes & 4 & $23.5 \%$ & 5 & $62.5 \%$ & 9 & $36.0 \%$ & 11 & $44.0 \%$ \\
\hline No & 10 & $58.8 \%$ & 3 & $37.5 \%$ & 13 & $52.0 \%$ & 10 & $40.0 \%$ \\
\hline Other & $2^{*}$ & $11.7 \%$ & 0 & $0.0 \%$ & 2 & $8.0 \%$ & $1^{* * *}$ & $4.0 \%$ \\
\hline No Answer & 1 & $5.8 \%$ & 0 & $0.0 \%$ & 1 & $4.0 \%$ & 3 & $12.0 \%$ \\
\hline Total & 17 & $99.8 \% * *$ & 8 & $100.0 \%$ & 25 & $100.0 \%$ & 25 & $100.0 \%$ \\
\hline
\end{tabular}

* Does not equal $100.0 \%$ due to rounding error.

** "I don't know"

"It doesn't matter"

*** "Depends" 
CHAPTER V

\section{SUMMARY AND CONCLUSION}

\section{Summary of Social Background}

Program and non-program patients were similar regarding certain characteristics of social background. These characteristics included age ranges with $82.0 \%$ of both groups being between the ages of 18-55. Eighty-four percent of both groups were Caucasian. Forty-four percent of the program patients and $52.0 \%$ of the non-program patients had attended high school and $24.0 \%$ of both groups indicated having had attended "some college". Eighty-eight percent of the program patients and $84.0 \%$ of the non-program patients were unemployed at the time of admission to the hospital. There were no patients of either group who earned more than $\$ 15,000$ a year. Forty percent of the program patients and $44.0 \%$ of the non-program patients were Protestants and the same percentages of both groups attended church only rarely. Fifty percent of the program patients and $56.0 \%$ of the non-program patients had not been arrested for any intoxicated related charges in the past year. Sixty-eight percent of the program patients and 64.0\% of the non-program patients had not been in a detoxification unit before being admitted into the hospital. Twelve percent of the program patients and $8.0 \%$ of the non-program patients were living with a spouse at the time of admission to the hospital. 
Program and non-program patients differed on certain characteristics of social background. Regarding the occupations of patients' fathers, $12.0 \%$ of the program patients and $40.0 \%$ of the non-program patients had fathers who were laborers. Forty percent of the program patients and $8.0 \%$ of the non-program patients reported being single. There were $56.0 \%$ of the program patients and $80.0 \%$ of the non-program patients who had no hobbies. Twenty-four percent of the program patients and $44.0 \%$ of the non-program patients were living alone before admission to the hospital. Sixteen percent of the program patients and $36.0 \%$ of the non-program patients had spent time in a penitentiary.

Summary of Alcohol Background

Regarding similarities in alcohol background, $92.0 \%$ of the program patients and $96.0 \%$ of the non-program patients believed they had a drinking problem. Forty-eight percent of the program patients and $44.0 \%$ of the non-program patients started drinking between the ages of 13-16. Sixty-four percent of both groups preferred to drink in a variety of places. Forty percent of the program patients and $36.0 \%$ of the non-program patients drank more than two quarts of wine daily. Forty-four percent of the program males and $72.0 \%$ of the non-program patients indicated that they drank to change their moods. Sixty percent of both groups had never tried to attempt suicide while drinking. Fifty-six percent of the program patients stated that there had been a history 
of drinking problems in their families.

In terms of differences in alcohol background, $24.0 \%$ of the program patients and $52.0 \%$ of the non-program patients preferred to drink alone. Forty percent of the program patients and $28.0 \%$ of the non-program patients described themselves as binge drinkers. Regarding treatment, $52.0 \%$ of the program patients and $36.0 \%$ of the non-program patients felt that a change in associates would be beneficial. Fiftysix percent of the program patients and $32.0 \%$ of the non-program patients believed that group therapy would be helpful. Fifty-two percent of the program patients and $28.0 \%$ of the non-program patients felt that individual therapy would be very important in treatment.

Summary of Medical/Psychological History

Similarities in medical/psychological history included no use of narcotics for $60.0 \%$ of the program patients and $56.0 \%$ of the non-program patients. Fifty-six percent of both groups weren't taking any medications at the time of the administration of the questionnaire. Thirty-two percent of the program patients and $28.0 \%$ of the non-program patients had previous community treatment of alcohol abuse. Fortyfour percent of the program patients and $40.0 \%$ of the non-program patients believed their health was worse now than a year ago.

Differences in medical/psychological history included previous hospitalizations for alcohol abuse. Thirty-six 
percent of the program patients and $72.0 \%$ of the non-program patients had been hospitalized for alcohol abuse before the current hospitalization. Sixteen percent of the program patients and $40.0 \%$ of the non-program patients believed their level of health was excellent. Forty percent of the program patients and $16.0 \%$ of the non-program patients indicated previous major medical and/or psychiatric treatment. There were $28.0 \%$ of the program patients and $56.0 \%$ of the non-program patients who had used antabuse in the past. Twenty-three percent of the program patients and $62.5 \%$ of the non-program patients would have preferred an alcohol program outside of a state hospital.

Conclusion

The results suggest that the program and non-program patients who were at Dammasch State Hospital during the month of June, 1976, were more similar than dissimilar regarding social background, alcohol background; and medical/psychological history.

There did appear to be differences between the two groups on preference for the treatment of alcoholism which might partially explain why certain patients had elected not to enter the Alcohol Treatment Program. Over half of the non-program patients, for example, would have preferred an alcohol program outside of a state hospital compared with less than one-fourth of the program patients. The non-program patients were also less enthusiastic about 
group and individual therapy than the program patients.

Other differences between the program and non-program patients could have been responsible for a preference in alcohol treatment. Non-program patients had more hospitalizations and had used antabuse more often than program patients. It might be possible that non-program patients felt they didn't get much out of previous hospitalizations and/or alcohol programs and they may have been blaming these programs for not helping them. Also, more non-program patients had fathers who were laborers than program patients. Perhaps these cultural differences created negative reactions to individual and group therapy. More non-program patients had been in the penitentiary than program patients and this may have provided a further cultural difference, making a specialized treatment program less desirable.

Besides the differences in desire for alcohol treatment, one other major difference seemed to be evident in the study. The theme of non-program patients being alone more often than program patients appeared to be reflected throughout the study. More non-program patients reported that they were living alone than program patients despite the statistic indicating that more program patients were single than nonprogram patients. This leads to the speculation that more non-program patients may have had difficulty living with others than would be true for the program patients. 
Several circumstances need to be mentioned when analyzing the results of the study. First, the results can only be examined in the context of the two groups of patients who were in the hospital during the month of June, 1976. No assurance could be made that these patients represented a typical, characteristic sample of alcohol patients at Dammasch State Hospital. Secondly, the census of the hospital for alcoholics was below normal and may have had an effect on providing a characteristic population. Thirdly, the Alcohol Treatment Program lost its funding for continued existence at the end of June, 1976. This may have prevented some patients who would have liked to receive treatment from entering the program.

Although these two groups of patients appeared to be more similar than dissimilar, the choice of desired treatment seemed to be different for each group and, at least for these patients, the main opportunity for alcohol treatment could not meet the needs and expectations of all eligible patients. This might imply a need for a more diversified choice of treatment.

Should the Alcohol Treatment Program ever receive funding in the future, another demographic study would be recommended where the collection of data extended over a longer period of time. 


\section{A Selected Bibliography}

Bateman, I. and M. Peterson. Variables Related to Outcome of Treatment of Hospitalized Alcoholics. International Journal of the Addictions. 1971, $6,214-224$.

Blaney, R.; I. Radford; and G. MacKenzie. A Belfast Study of Prediction of Outcome in the Treatment of Alcoholism. British Journal of Addiction, 1975, 70, 114.

Blum, E. Psychoanalytic Views of Alcoholism: A Review. Quarterly Journal of Studies on Alcohol, 1966, 27, 263.

Bowman, R; L. Stein; and J. Newton. Measurement and Interpretation of Drinking Behavior. Journal of Studies on Alcohol, 1975, 36, 1154-1171.

Cahalan, D.; I. Cisin; and H. Crossley. American Drinking Practices. New Haven, Conn.: College and University Press, 1969.

Cahalan, D. Problem Drinkers. San Francisco: Jossey-Bass, Inc., 1970.

Chafetz, M. and H. Demone. Alcoholism and Society.

New York: Oxford University Press, 1962.

Coffler, D. and R. Hadley. The Residential Rehabilitation Center as an Alternative to Jail for Chronic Drunkenness Offenders. Quarterly Journal of Studies on Alcohol, $1973, \underline{34}, 1180-1186$.

Crowley, T.; D. Chesluk; S. Dilts; and R. Hart. Drug and Alcohol Abuse Among Psychiatric Admissions: A Multidrug Clinic-Tosieologic Study. Archives of General Psychiatry, 1974, 30, 13-20.

Deardorff, D.; F. Melges ; C. Hout ; and D. Savage. Situa = tions Related to Drinking Alcohol. Journal of Studies on Alcohol, $1975, \underline{36}, 1187$.

Emrick, C. A Review of Psychologically Oriented Treatment of Alcoholism. Journal of Studies on Alcohol, 1975, $\underline{36}, 88$.

Felde, R. Alcoholics Before and After Treatment. Newsletter for Research in Mental Health and Behavioral Sciences, $1974,15,32-34$.

Fryer, J. Attendance at Out-Patient Clinics as a Function of Risk Taking for Alcoholics. Portland, Ore.: Portland State University, 1975. 
Hamlin, R. and P. Haskin. IMPS Syndromes and Treatment for Alcoholism. Newsletter for Research in Mental Health and Behavioral Sciences, 1973, 15, 56-66.

Hoffmann, H. and A. Noem. Alcoholism Among Parents of Male and Female Alcoholics. Psychological Reports, 1975, 36, 1322 .

Hoffmann, H. Country Characteristics and Admission to State Hospital for Treatment of Alcoholism and Psychiatric Disorders. Psychological Reports, 1974, 35, 1275-1277.

Hoffmann, H.; D. Jackson; and H. Skinner. Dimensions of Psychopathology among Alcohol Patients. Journal of Studies on Alcohol, $1975, \underline{36}, 826-836$.

Hoffmann, H. and A. Noem. Sex Differences in a State Hospital Population of Alcoholics on Admission and Treatment Variables. Psychological Reports, 1975, 37, 145-146.

Hore, B. and E. Smith. Who Goes to Alcoholic Units? British Journal of Addiction, 1975, 70, 263-270.

Horn, J.; K. Wanberg; and F. Foster. The Alcohol Use Inventory. Denver: Center of Alcohol-Abuse Research and Evaluation, 1974.

Horn, J.; K. Wanberg; and G. Adams. Diagnosis of Alcoholism: Factors of Drinking, Background, and Current Conditions in Alcoholics. Quarterly Journal of Studies on Alcohol, $1974, \underline{35}, 147-175$.

Israel, $\mathrm{Y}$. and $\mathrm{J}$. Mardones. Biological Basis of Alcoholism. New York: Wiley-Interscience, 1971.

Jansen, D. and H. Hoffmann. Demographic and MMPI Characteristics of Male and Female State Hospital Alcoholic Patients. Psychological Reports, 1973, 33, 561-562.

Jansen, D. and H. Hoffmann. The Influence of Age, Intelligence, and Education Level on Shipley-Harford conceptual Quotients of State Hospital Alcoholics. Journal of Clinical Psychology, 1973, 29, 468-470

Jellinek, E. The Disease Concept of Alcoholism. New York: College and University Press, 1960.

Kuehnle, J.; W. Anderson; and E. Chandler. First Drinking Experience in Addictive and Non-Addictive Drinkers, Archives of General Psychiatry, 1974, 31, 
Maxwe11, W; R. Bair; T. Wez1; and L. Ferguson. Discriminated Aversion Conditioning Within an Alcohol Treatment Program in the Training of Controlled Drinking. Behavioral Engineering, 1974, 2, 17-10.

Newton, J. and L. Stein. Implosive Therapy, Duration of Hopitalization, and Degree of Coordination of Aftercare Services with Alcoholics. Research on Alcoholism: Clinical Problems and Special Population, 1973, DHEW Publication No. 73-9074, 130-137.

Pattison, E. Population Variation among Alcoholism Treatment Facilities. International Journal of the Addictions, $1973,8,199-229$.

Roebuck, J. and R. Kessler. The Etiology of Alcoholism. Springfield, Illinois: Charles C. Thomas, 1972.

Selzer, M; A. Vinokur; and L. Van Rooijen. A Self-Administered Short Michigan Alcoholism Screening Test. Journal of Studies on Alcohol, 1975, 36, 117-26.

Shore, R. Treat the Alcoholic, But Not with Asylums. Research on Alcoholism: Clinical Problems and Special Populations. 1973, DHEW Publication No. 73-9074, 179-186.

Stein, L.; J. Newton; and R. Bowman. Duration of Hospitalization for Alcoholism. Archives of General Psychiatry, $1975,32,247-252$.

Steiner, C. Games Alcoholics Play. New York: Ballantine Books, 1971 .

Strauss, J.; D. Wolfe; A. Van Ord; and R. Geoghegan. Inpatient Alcoholics: Characteristics and Needs. Comprehensive Psychiatry, 1974, 15, 205-212.

Tomsovic, M. Group Therapy and Changes in the Self-Concept of Alcoholics. Journal of Studies on Alcohol, 1976, 37, 54-56.

The Committee on Nomenclature and Statistics of the American Psychiatric Association. Diagnostic and Statistical Manual of Mental Disorders. Washington, D.C.: American Psychiatric Association, 1968.

Vogler, R.; J. Compton; and T. Weissback. Integrated Behavior Change Techniques for Alcoholics. Journal of Consulting and Clinical Psychology. $1975, \frac{143,233-243}{4}$

Wanberg, K.; J. Horn; and D. Fairchild. Hospital Versus Community Treatment of Alcoholism Problems. International Journal of Mental Health, $1974, \underline{3} 160-176$. 
Wanberg, K. and E. Jones. Intial Contact and Admission of Persons Requesting Treatment for Alcohol Problems. British Journal of Addiction, $1973, \underline{68}, 281-285$.

Wanberg, K. and J. Knapp. A multidimensional Model for the Research and Treatment of Alcoholism. International Journal of the Addictions, $1970,5,69-98$. 
SHOI बNHddV 


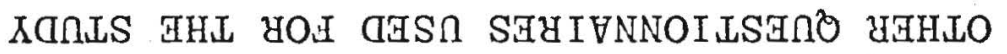

$\forall$ XICNAdd 


\section{APPENDIX A}

OTHER QUESTIONNAIRES USED FOR THE STUDY

\begin{tabular}{|c|c|}
\hline QUESTIONNAIRES & NUMBER OF QUESTION \\
\hline $\begin{array}{l}\text { MULTI-DIMENSIONAL OUTCOMA } \\
\text { MEASURE }\end{array}$ & $\begin{array}{r}\text { Questions } 3,4,10,13,17,28,29,30 \\
\text { and } 32\end{array}$ \\
\hline Horn and Smith (1975) & Question 7 \\
\hline $\begin{array}{l}\text { Kuehnle, Anderson, and } \\
\text { Chandler (1974) }\end{array}$ & Question 40 \\
\hline Wanberg and Knapp (1970) & $\begin{array}{l}\text { Questions } 42,43,44,45,46,47,48 \text {, } \\
50,53,56,57,59,60,61,62 \text {, and } 64\end{array}$ \\
\hline $\begin{array}{c}\text { Horn, Wanberg, and Foster } \\
\text { (1974) }\end{array}$ & Questions 51 and 58 \\
\hline
\end{tabular}


XGกLS AHL YOA GUIVNNOILSAกO

घ XIaNGddY 
please respond to each of the following questions by checking the answer which is most appropriate for you. Some of the questions ask you to fill in your answer. Be as specific as possible.

ALL INFORMATION WILL BE STRICTLY CONFIDENTIAL.

Social Background

I. Male Female

2. What is your age?

3. What is your ethnic group.

a. Caucasian

b. Black

c. Mexican-American d. Indian

e. Oriental

f._other

4. Who did you reside with for most of your early life?
a.__ parent
b. relatives
c. institution
d. foster parents
e._other (please specify):

5. Number of brothers (specific number)

Number of sisters (specific number)

6. In order of sibling birth, what number were your?

a. youngest

b. middle

c. oldest

d. I was the only child.

7. Whether living of deceased, state the occupation of:
a. father:
b. mother:
c. guardian (ignore if doesn't apply to you): 
8. What was the highest level of education for your father and mother?
a. father (check one only):
a._ grades $1-8$
$\mathrm{~b} . \quad$ grades $9-12$
c._ some college
d. Bachelors Degree
e. Advanced Degree (Master's, Ph.D, etc.)
f. Technical of Business
g. I don't know
b. mother (check one only): a. grades 1-8
b. Grade $9-12$
d. Bachelors Degree
e. Advanced Degree (Master's, Ph.D, etc.)
f. Technical of Business
School
g. I don't know

9. What was the highest level of education for yourself?
a._grades 1-8
b. Zrades 9-12
c. some college
d. Bachelors Degree
e._Advanced Degree (Master's Ph.D, etc.
f. Technical of Business School

10. What is your main source of income?
a. public support
c. employment
b._family support
d. other self-support

11. Were you employed at the time of admission to this hospital?
a. yes
b. no

12. What type of employment?

13. How many jobs have you held in the past year? 
14. What is your annual gross income?
a. $0-2999$
b. $3000-3999$
c. $4000-4999$
d. $5000-5999$
e. $6000-6999$
f. 7000-7999
g. $-8000-8999$
h. -9000-9999
i. 10000-14999
j. 15000 and over

15. Do you currently owe any debts?
a.
b. yes no

16. What is your current marital status?
a. single
b. married
e. widowed
c. divorced
f. remarried separated
g. non-legal

d.

17. How many times have you been married?

18. Do you have any children?

$\mathrm{b}$.__ no

19. How many children are in each age group (please indicate the specific number of children in each category)

a. pre-school c. high school

b._grade school d._post high school

20. What is your religion?
a. Protestant
b. Jewish
c. Catholic

d. none

21. Do you attend church (please check one only)

a. once a week or more

b. - about once or twice a month

c. a few times during the year

d. only rarely

e. never

22. Do you currently have any hobbies or belong to any recreational organizations such as the YMCA, church group, Elks Lodge, etc.?
a. yes
b. no 
If your answer is yes to question 22 , please 1 ist hobbies or recreational organizations below:

23. How long have you lived in Oregon?

a. less than 1 year

b. $1-5$ years

c. $5-10$ years

d. More than 10 years

e._All my life

24. How many times have you moved in the last year?

25. Were you in Detox before entering the hospital?

a.__yes

b. _ no

26. What was your living situation for the month before entering this hospital?
a. living alone
d. with relatives
b. with friends
e. other (please specify):
c. with spouse

27. How may close friends do you have in your community?
a. 6 or more
b. $3-5$
c. 1-2
d. none

28. How many times in the past year have you been arrested on intoxication related charges (drunken driving, driving while intoxicated, driving under the influence of alcoholic beverages)?
a. never
c. 3-5 times
b. - once or twice
c. 6 or more times

29. How many times in the past year have you been arrested for anything else?
a. never
c. 3-5 times
b. once or twice
d. 6 or more times

30. Have you spent any time in the penitentiary?
a. yes
b. no

31. Do you have any current charges against you?
a. yes
b. no 
If yes, is the current charge due to:

a. intoxication

b. _other (please specify):

\section{Alcohol Background}

32. Do you feel you have a drinking problem?

a. yes

b. no

33. Describe your first drinking experience by answering the items below:

a. Age when you had your first drink:

b. beverage used:

c. amount consumed:

d. with whom:

e. reaction:

f. other circumstances:

g. I don't remember.

34. If you believe you have a drinking problem, when did it start to be a problem?

35. How do you usually drink?

a. alone

b. with others

36. In which of the following places did you most usually drink before coming to the hospital?

a. at home

b. in a bar

c._ in several places (home, bar, with friends, etc.)

37. How much wine did you drink in a day on the average before coming to the hospital?
a. none
b. - $\frac{1}{2} q u a r t$ or less
d. two quars
c. one quart
e. more than two quarts

38. How much beer did you drink in a day on the average before coming to the hospital?

a. none

b. less than a quart ( $1-3$ cans)

c. up to two quarts ( $4-6$ cans)

d. up to three quarts (7-10 cans)

e. more than three quarts 
39. How much hard liquor did you drink in a day on the average before coming to the hospital?
a. none
b. - pint
c. pint
d. quart
e. more than one quart

40. How much of other substitutes did you drink in a day on the average before coming to the hospital

(shaving lotion, hair tonic, cough syrup, etc.)?

a. none

b. $\frac{1}{2}$ pint

c._pint

d. quart

e. more than on quart

41. Have you been able to stop drinking by yourself?

a. yes

b. no

42. How would you describe your drinking pattern before coming to the hospital?

a. binge drinking (drinking for several days, then remaining sober for several days)

b.__ continuous drinking

c. _other (please specify):

Questions 43 through 47 are to be answered by people who described themselves as binge drinkers in question 42 . Please answer according to your drinking pattern before entering the hospital.

43. When you drink, do you drink several days, then sober up for a period of time before drinking again?

a. yes, usually

b._yes, sometimes

c. no

44. The last time you were drinking, how many days did your drinking continue? days

45. If you haven't been drinking everyday, how long between drinking bouts on the average? ___ days

46. When you stop drinking, do you usually:

a._stop completely

b. - taper off

c. I have not been able to stop recently 
47. Usually how much time is there between your periods of drinking-time when you don't drink at all?

a. less than a week

b. up to a month

c. more than a month

48. Were you intoxicated when you were admitted into this hospital?

a. yes

b. no

49. Has you drinking ever been responsible for loss of employment (either through quitting or being fired)?

b._ yes

If yes, how often have you lost employment due to drinking?

50. For questions a. through g., please indicate how important you would say that each of the following is to you as a reason for drinking-very important, fairly important, or not at all important.

VERY FAIRLY NOT AT ALL IMPORTANT IMPORTANT IMPORTANT

a. I drink because it helps me relax

b. I drink to be sociable

c. I drink when I want to forget unpleasant thoughts

d. I drink so I will feel less depressed and anxious

e. I drink to relieve angry feelings

f. I drink so I can relate my feelings and thoughts to the opposite sex

g. I drink to change my mood

51. Do you tend to shut out the world when drinking?

a._yes, usually

b._yes, sometimes

c. no

52. Do you ever feel guilty about your drinking?

a. yes, usually

b._yes, sometimes

c. no 
53. Do you get angry or start fights when you drink?
a. yes, usually
b. yes, sometimes
c. no

54. Have you ever attempted suicide when drinking?

a. never

b. once

c. - several times

55. Does your drinking cause hardships for your family and/or friends.

a. yes

$\mathrm{b} \cdot \ldots$ no

56. Has your wife, husband, a parent, or other near relative ever sought professional help about your drinking?

a. yes

b. no

57. Are your currently experiencing any family disruption due to drinking (divorce, separation, etc.)/ a. yes

$\mathrm{b} \cdot \mathrm{no}_{\mathrm{n}}$

58. Is there any history of drinking problems in your family?

a. yes

$\mathrm{b} \cdot \mathrm{no}_{\mathrm{n}}$

If yes, please indicate below whether this would include your mother, father, children, siblings, etc.:

59. Do you want to stop drinking completely?

a. yes

b. no.

60. For questions a. through f., please answer how you would rate the following items in terms of being helpful for you in treatment of alcohol abuse--very importnat, fairly important, or not at all important.

VERY FAIRLY NOT AT ALL IMPORTANT IMPORTANT IMPORTANT

a. change in living situation

b. change in associates

c. group therapy

d. Alcoholics Anonymous

e. individual therapy

f. education on effects of alcohol

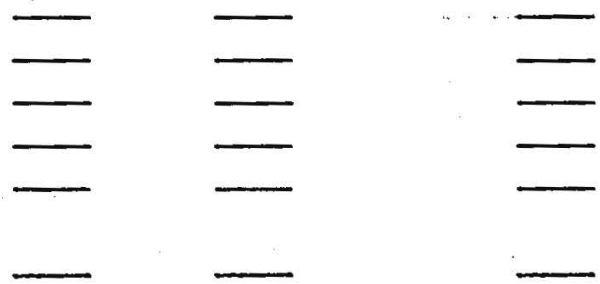


Medical/Psychological History

61. Have you had nay previous hospitalizations (including Detox) for alcohol abuse?

a. yes

b. no

62. If you have had previous hospitalizations for alcohol abuse, when did these occur, and where were you hospitalized?

a. Number of hospitalizations:

DATE OF HOSPITALIZATION

LOCATION OF HOSPITALIZATION

63. Have you had any community treatment for alcohol abuse (mental health clinic, alcohol treatment clinic, etc.)? a. yes

b. no

If yes, when and where did you receive community treatment?

DATE OF COMMUNITY TREATMENT LOCATION OF COMMUNITY TREATMENT

64. Would you say that your health is usually excellent, good, fair, or poor?

a. excellent

b. good

c. fair

d._poor 
65. Compared with a year ago, would you say that your health was better, worse, or about the same before entering the hospital?
a. better now
b. worse now
c. about the same

66. Other than alcohol abuse, have you had any major medical or psychiatric problems treated?
a. yes
b. no

MEDICAL/PSYCHIATRIC PROBLEM WHEN TREATED WHERE

67. Have you ever used hard narcotics (such as heroin, morphine, speed, etc.)?

a. never

b. - once or twice

c._several times

68. Have your used antabuse to help you to stop drinking?

a. yes

b. no

69. If you have used antabuse, did you drink on it?

a.__yes

b. no

If yes, what was your reaction?

70. What medications are you taking at the present?

71. How did you hear about Dammasch State Hospital? 
72. How did you hear about the Alcohol Treatment Program at Dammasch State Hospital?

a. I'm not familiar with this program.

73. If there was a similar inpatient alcohol treatment program available that was not in a state hospital, would you prefer that type of treatment program?

a. yes

b. no 


\section{HJIWS \\ aNV अभYH $x \notin$ बHNDISHA \\ GYIVNNOILSARO AפVd GNO $\mathrm{V}$ \\ S XIGNHddV}




\section{APPENDIX C}

A ONE PAGE QUESTIONNAIRE

DESIGNED BY HORE AND SMITH

Name of Unit

(1) Age of patient

(2) Sex of patient

(3) Type of secondary school attended (please ring)

(i) Grammar

(ii) Secondary Modern

(iii) Comprehensive

(iv) Other-please state

(4) Patient's present occupation (as specific as possible). If unemployed, last job, with dates.

(5) Most responsible and skilled job ever held

(6) Occupation of patient's husband or wife

(7) Was patient reared by (i) parents

(ii) relatives

(iii) institutions

(iv) other-please state

(8) Occupation of

(i) Patient's father(as specific as possible)

(ii) Patient's mother

(iii) Parent substitute (delete if inapplicable) 
(9) I.Q. If available (Please state test)

(10) Patient's social stability (Strauss and Bacon Scale 1951) (Please tick answer).

(i) Ever held a steady job for a least three years

YES/NO

(ii) Living in town of present residence for at least two years.

(iii) Living in own home or that of relatives or friends, prior to admission

(iv) Married and living with spouse 
SLTASAY TVNOIJIGAV

a XIबNHddV 
TABLE XXIX

ETHNIC GROUP

\begin{tabular}{|c|c|c|c|c|c|c|c|c|}
\hline \multirow{2}{*}{$\begin{array}{l}\text { Ethnic } \\
\text { Group }\end{array}$} & \multicolumn{2}{|c|}{ Program Males } & \multicolumn{2}{|c|}{ Program Females } & \multicolumn{2}{|c|}{ Sub-Total } & \multicolumn{2}{|c|}{ Non-Program Males } \\
\hline & $\begin{array}{l}\text { Freq. of } \\
\text { response }\end{array}$ & Percent & $\begin{array}{l}\text { Freq. of } \\
\text { response }\end{array}$ & Percent & $\begin{array}{l}\text { Freq. of } \\
\text { response }\end{array}$ & Percent & $\begin{array}{l}\text { Freq. of } \\
\text { responce }\end{array}$ & Percent \\
\hline Caucasian & 15 & $88.0 \%$ & 6 & $75.0 \%$ & 21 & $84.0 \%$ & 21 & $84.0 \%$ \\
\hline Black & 0 & $0.0 \%$ & 2 & $25.0 \%$ & 2 & $8.0 \%$ & 2 & $8.0 \%$ \\
\hline Mex-Am & 0 & $0.0 \%$ & 0 & $0.0 \%$ & 0 & $0.0 \%$ & 1 & $0.0 \%$ \\
\hline Am-Indian & 1 & $6.0 \%$ & 0 & $0.0 \%$ & 1 & $4.0 \%$ & 1 & $4.0 \%$ \\
\hline Other & 1 & $6.0 \%$ & 0 & $0.0 \%$ & 1 & $4.0 \%$ & 0 & $0.0 \%$ \\
\hline Total & 17 & $100.0 \%$ & 8 & $100.0 \%$ & 25 & $100.0 \%$ & 25 & $100.0 \%$ \\
\hline
\end{tabular}


TABLE XXX

PERSONS WITH WHOM PATIENTS RESIDED FOR MOST OF THEIR EARLY LIFE

\begin{tabular}{|c|c|c|c|c|c|c|c|c|}
\hline \multirow{2}{*}{$\begin{array}{l}\text { Place of } \\
\text { residence }\end{array}$} & \multicolumn{2}{|c|}{ Program Males } & \multicolumn{2}{|c|}{ Program Females } & \multicolumn{2}{|c|}{ Sub-Total } & \multicolumn{2}{|c|}{ Non-program Males } \\
\hline & $\begin{array}{l}\text { Freq. of } \\
\text { response }\end{array}$ & Rercent & $\begin{array}{l}\text { Freq. of } \\
\text { response }\end{array}$ & Percent & $\begin{array}{l}\text { Freq.of } \\
\text { response }\end{array}$ & Percent & $\begin{array}{l}\text { Freq. of } \\
\text { response }\end{array}$ & Percent \\
\hline Parents & 15 & $88.0 \%$ & 5 & $62.0 \%$ & 20 & $80.0 \%$ & 21 & $84.0 \%$ \\
\hline Relatives & 0 & $0.0 \%$ & 2 & $25.0 \%$ & 2 & $8.0 \%$ & 1 & $4.0 \%$ \\
\hline Institution & 1 & $5.8 \%$ & 1 & $13.0 \%$ & 2 & $8.0 \%$ & 1 & $4.0 \%$ \\
\hline $\begin{array}{l}\text { Foster } \\
\text { parents }\end{array}$ & 0 & $0.0 \%$ & 0 & $0.0 \%$ & 0 & $0.0 \%$ & 1 & $4.0 \%$ \\
\hline No answer & 1 & $5.8 \%$ & 0 & $0.0 \%$ & 1 & $4.0 \%$ & 1 & $4.0 \%$ \\
\hline Total & 17 & $99.6 \% *$ & 8 & $100.0 \%$ & 25 & $100.0 \%$ & 25 & $100.0 \%$ \\
\hline
\end{tabular}

* Does not equal $100.0 \%$ due to rounding error. 
TABLE XXXI

NUMBER OF BROTHERS

\begin{tabular}{|c|c|c|c|c|c|c|c|c|}
\hline \multirow{2}{*}{$\begin{array}{l}\text { Number of } \\
\text { Brothers }\end{array}$} & \multicolumn{2}{|c|}{ Program Males } & \multicolumn{2}{|c|}{ Program Females } & \multicolumn{2}{|c|}{ Sub-Total } & \multicolumn{2}{|c|}{ Non-Program Males } \\
\hline & $\begin{array}{l}\text { Freq. of } \\
\text { response }\end{array}$ & Percent & $\begin{array}{l}\text { Freq.of } \\
\text { response }\end{array}$ & Percnet & $\begin{array}{l}\text { Freq.of } \\
\text { response }\end{array}$ & Percent & $\begin{array}{l}\text { Freq. of } \\
\text { response }\end{array}$ & Percent \\
\hline 0 & 5 & $29.4 \%$ & 2 & $25.0 \%$ & 7 & $28.0 \%$ & 8 & $32.0 \%$ \\
\hline 1 & 4 & $23.5 \%$ & 2 & $25.0 \%$ & 6 & $24.0 \%$ & 6 & $24.0 \%$ \\
\hline 2 & 4 & $23.5 \%$ & 0 & $0.0 \%$ & 4 & $16.0 \%$ & 5 & $20.0 \%$ \\
\hline 3 & 2 & $11.7 \%$ & 2 & $25.0 \%$ & 4 & $16.0 \%$ & 5 & $20.0 \%$ \\
\hline 4 & 2 & $11.7 \%$ & 0 & $0.0 \%$ & 2 & $8.0 \%$ & 0 & $0.0 \%$ \\
\hline 5 & 0 & $0.0 \%$ & 0 & $0.0 \%$ & 0 & $0.0 \%$ & 1 & $4.0 \%$ \\
\hline No answer & 0 & $0.0 \%$ & 2 & $25.0 \%$ & 2 & $8.0 \%$ & 0 & $0.0 \%$ \\
\hline Tota1 & 17 & $99.4 \% *$ & 8 & $100.0 \%$ & 25 & $100.0 \%$ & 15 & $100.0 \%$ \\
\hline
\end{tabular}

* Does not equal $100.0 \%$ due to rounding error. 
TABLE XXXII

NUMBER OF SİSTERS

\begin{tabular}{|c|c|c|c|c|c|c|c|c|}
\hline \multirow{2}{*}{$\begin{array}{l}\text { Number of } \\
\text { Sisters }\end{array}$} & \multicolumn{2}{|c|}{ Program Males } & \multicolumn{2}{|c|}{ Program Females } & \multicolumn{2}{|c|}{ Sub-Total } & \multicolumn{2}{|c|}{ Non-Program Males } \\
\hline & $\begin{array}{l}\text { Freq.of } \\
\text { response }\end{array}$ & Percent & $\begin{array}{l}\text { Freq of } \\
\text { responise }\end{array}$ & Percent & $\begin{array}{l}\text { Freq. of } \\
\text { response }\end{array}$ & Percent & $\begin{array}{l}\text { Ereq of } \\
\text { response }\end{array}$ & Percent \\
\hline 0 & 3 & $17.6 \%$ & 1 & $12.5 \%$ & 4 & $16.0 \%$ & 5 & $20.0 \%$ \\
\hline 1 & 4 & $23.5 \%$ & 4 & $50.0 \%$ & 8 & $32.0 \%$ & 2 & $8.0 \%$ \\
\hline 2 & 5 & $29.4 \%$ & 0 & $0.0 \%$ & 5 & $20.0 \%$ & 4 & $16.0 \%$ \\
\hline 3 & 0 & $0.0 \%$ & 1 & $12.5 \%$ & 1 & $4.0 \%$ & 3 & $12.0 \%$ \\
\hline 4 & 1 & $5.8 \%$ & 0 & $0.0 \%$ & 1 & $4.0 \%$ & 0 & $0.0 \%$ \\
\hline 6 & 1 & $5,8 \%$ & 0 & $0.0 \%$ & 1 & $4.0 \%$ & 0 & $0.0 \%$ \\
\hline 7 & 1 & $5.8 \%$ & 0 & $0.0 \%$ & 1 & $4.0 \%$ & 0 & $0.0 \%$ \\
\hline 9 & 0 & $0.0 \%$ & 0 & $0.0 \%$ & 0 & $0.0 \%$ & 1 & $4.0 \%$ \\
\hline 11 & 0 & $0.0 \%$ & 0 & $0.0 \%$ & 0 & $0.0 \%$ & 1 & $4.0 \%$ \\
\hline No answer & 2 & $11.7 \%$ & 2 & $25.0 \%$ & 4 & $16.0 \%$ & 9 & $36.0 \%$ \\
\hline Total & 17 & $99.6 \% *$ & 8 & $100.0 \%$ & 25 & $100.0 \%$ & 25 & $100.0 \%$ \\
\hline
\end{tabular}

* Does not equal $100.0 \%$ due to rounding error. 
TABLE XXXIII

OCCUPATION OF FATHER

\begin{tabular}{|c|c|c|c|c|c|c|c|c|}
\hline \multirow{2}{*}{$\begin{array}{l}\text { Occupation } \\
\text { of } \\
\text { Father }\end{array}$} & \multicolumn{2}{|c|}{ Program Males } & \multirow{2}{*}{$\begin{array}{l}\text { Occupation } \\
\text { of } \\
\text { Father }\end{array}$} & \multicolumn{2}{|c|}{ Program Females } & \multirow{2}{*}{$\begin{array}{l}\text { Occupation } \\
\text { of } \\
\text { Father }\end{array}$} & \multicolumn{2}{|c|}{ Non-Program Mas. } \\
\hline & $\begin{array}{l}\text { Freq. of } \\
\text { response }\end{array}$ & Percent & & $\begin{array}{l}\text { Freq. of } \\
\text { response }\end{array}$ & Percent & & $\begin{array}{l}\text { Freq. } \\
\text { of res }\end{array}$ & Percent \\
\hline Laborer & 2 & $11.7 \%$ & Laborer & 1 & $12.5 \%$ & Laborer & 10 & $40.0 \%$ \\
\hline Factory & 3 & $17.6 \%$ & Lumberjack & 1 & $12.5 \%$ & Gardener & 1 & $4.0 \%$ \\
\hline Machinist & 1 & $5.8 \%$ & Machinist & 1 & $12.5 \%$ & Bookkeeper & 1 & $4.0 \%$ \\
\hline Sales & 1 & $5.8 \%$ & Business & 1 & $12.5 \%$ & Salesman & 3 & $12.0 \%$ \\
\hline Bus Driver & 1 & $5.8 \%$ & Teacher & 1 & $12.5 \%$ & Truck Driver & & \\
\hline Dir. of & 1 & $58 \%$ & Weldar & 1 & 125 & Mechanic & 1 & $4.0 \%$ \\
\hline Don't know & 1 & $5.8 \%$ & & & & $\begin{array}{l}\text { Unemployed } \\
\text { WWI Veteran }\end{array}$ & $\begin{array}{l}1 \\
1\end{array}$ & $\begin{array}{l}4.0 \% \\
4.0 \%\end{array}$ \\
\hline No answer & 7 & $41.1 \%$ & No answer & 1 & $12.5 \%$ & No answer & 6 & $24.0 \%$ \\
\hline Total & 17 & $99.4 \%^{*}$ & Total & 8 & $100.0 \%$ & No answer & 25 & $100.0 \%$ \\
\hline
\end{tabular}

*Does not equal $100.0 \%$ due to rounding error. 
TABLE XXXIV

\section{OCCUPATION OF MOTHER}

\begin{tabular}{|c|c|c|c|c|c|c|c|c|}
\hline \multirow{2}{*}{$\begin{array}{l}\text { Occupation } \\
\text { of } \\
\text { Mother }\end{array}$} & \multicolumn{2}{|c|}{ Program Males } & \multirow{2}{*}{$\begin{array}{l}\text { Occupation } \\
\text { of } \\
\text { Mother }\end{array}$} & \multicolumn{2}{|c|}{ Program Females } & \multirow{2}{*}{$\begin{array}{l}\text { Occupation } \\
\text { of } \\
\text { Mother }\end{array}$} & \multicolumn{2}{|c|}{$\begin{array}{l}\text { Non-Program } \\
\text { Males }\end{array}$} \\
\hline & $\begin{array}{l}\text { Ereq.of } \\
\text { response }\end{array}$ & Percent & & $\begin{array}{l}\text { Freq.of } \\
\text { response }\end{array}$ & Percent & & $\begin{array}{l}\text { Freq. } \\
\text { bf res }\end{array}$ & Percent \\
\hline Housewife & 5 & $29.4 \%$ & Housewife & 4 & $50.0 \%$ & Housewife & 16 & $64.0 \%$ \\
\hline Shipyard & 1 & $5.8 \%$ & waitress & 1 & $12.5 \%$ & Laborer & 3 & $12.0 \%$ \\
\hline R.N. & 1 & $5.8 \%$ & R.N. & 1 & $12.5 \%$ & R.N. & 1 & $4.0 \%$ \\
\hline Supervisor & 1 & $5.8 \%$ & Bookkeeper & 1 & $12.5 \%$ & Bridge Teache & 1 & $4.0 \%$ \\
\hline Sales & 1 & $5.8 \%$ & & & & Sales & 1 & $4.0 \%$ \\
\hline No answer & 8 & $47.0 \%$ & No answer & 1 & $12.5 \%$ & No answer & 3 & $12.0 \%$ \\
\hline Total & 17 & $99.6 \%^{*}$ & Fotal & 8 & $100.0 \%$ & Total & 85 & $100.0 \%$ \\
\hline
\end{tabular}

* Does not equal $100.0 \%$ due to rounding error. 
TABLE XXXV

PATIENTS WHO WERE EMPLOYED AT THE TIME OF ADMISSION TO THE HOSPITAL

\begin{tabular}{|c|c|c|c|c|c|c|c|c|}
\hline \multirow[t]{2}{*}{ Employed } & \multicolumn{2}{|c|}{ Program Males } & \multicolumn{2}{|c|}{ Program Females } & \multicolumn{2}{|c|}{ Sub-Total } & \multicolumn{2}{|c|}{ Non-Program Males } \\
\hline & $\begin{array}{l}\text { Freq. of } \\
\text { response }\end{array}$ & Percent & $\begin{array}{l}\text { Freq. of } \\
\text { response }\end{array}$ & Percent & $\begin{array}{l}\text { Freq. of } \\
\text { response }\end{array}$ & Percent & $\begin{array}{l}\text { Freq.of } \\
\text { response }\end{array}$ & Percent \\
\hline Yes & 4 & $23.5 \%$ & 1 & $12.5 \%$ & 5 & $20.0 \%$ & 3 & $12.0 \%$ \\
\hline No & 13 & $76.5 \%$ & 7 & $87.5 \%$ & 20 & $80.0 \%$ & 21 & $84.0 \%$ \\
\hline No answer & 0 & $0.0 \%$ & 0 & $0.0 \%$ & 0 & $0.0 \%$ & 2 & $8.0 \%$ \\
\hline Total & 17 & $100.0 \%$ & 8 & $100.0 \%$ & 25 & $100.0 \%$ & 25 & $100.0 \%$ \\
\hline
\end{tabular}


TABLE XXXVI

PATIENTS' TYPE OF EMPLOYMENT

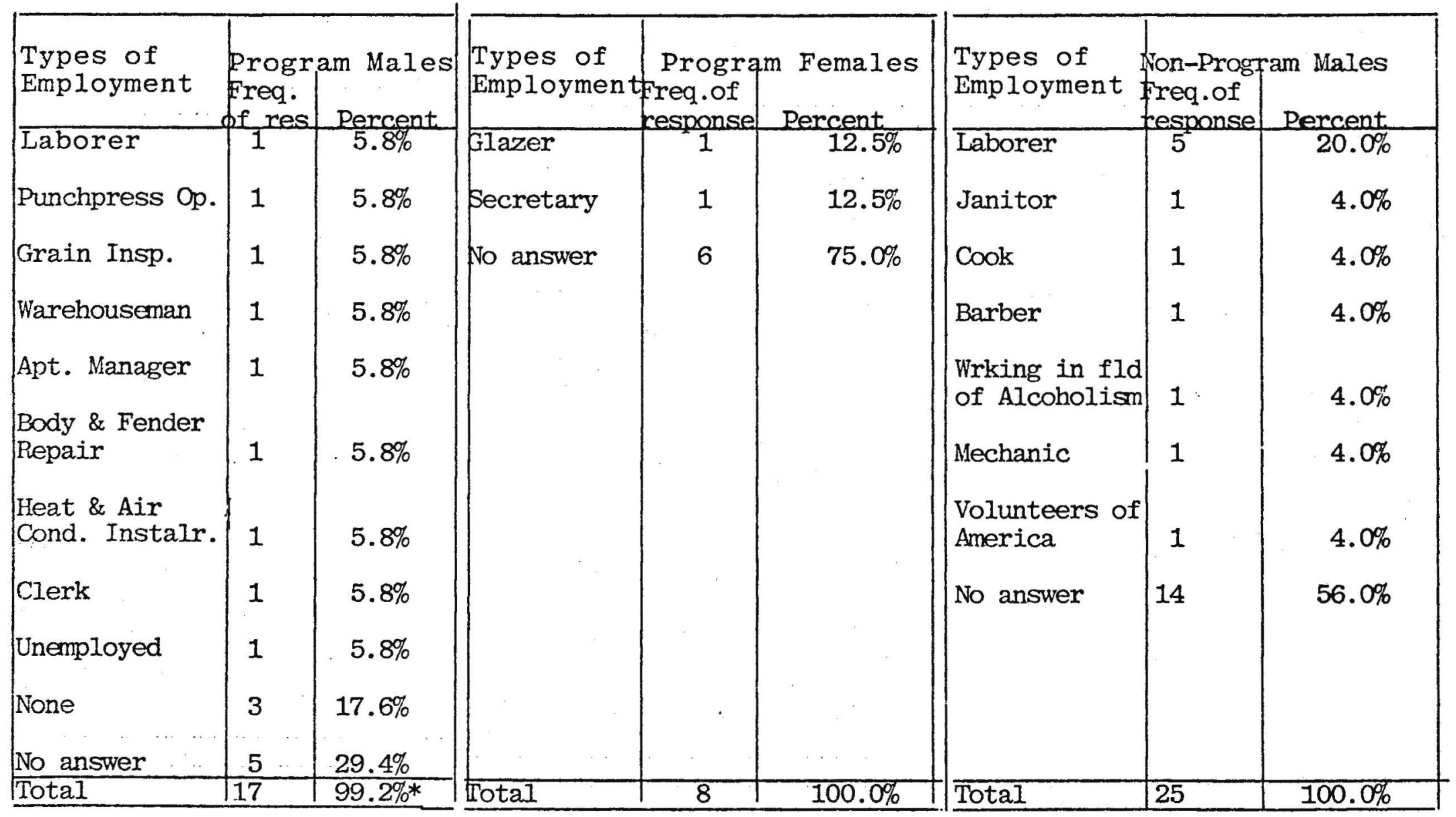

* Does not equal $100.0 \%$ due to rounding error. 
TABLE XXXVII

NUMBER OF JOBS HELD IN THE PAST YEAR

\begin{tabular}{|c|c|c|c|c|c|c|c|c|}
\hline \multirow{2}{*}{$\begin{array}{l}\text { Number of } \\
\text { Jobs }\end{array}$} & \multicolumn{2}{|c|}{ Program Males } & Program & Females & \multicolumn{2}{|c|}{ Sub-Total } & \multicolumn{2}{|c|}{ Non-Program Males } \\
\hline & $\begin{array}{l}\text { Freq. of } \\
\text { response }\end{array}$ & Percent & $\begin{array}{l}\text { Freq. of } \\
\text { response }\end{array}$ & Percent & $\begin{array}{l}\text { Freq. of } \\
\text { response }\end{array}$ & Percent & $\begin{array}{l}\text { Freq.of } \\
\text { response }\end{array}$ & Percent \\
\hline None & 4 & $23.5 \%$ & 3 & $37.5 \%$ & 7 & $28.0 \%$ & 6 & $24.0 \%$ \\
\hline $1-2$ & 8 & $47.0 \%$ & 2 & $25.0 \%$ & 10 & $40.0 \%$ & 15 & $60.0 \%$ \\
\hline $3-4$ & 0 & $0.0 \%$ & 0 & $0.0 \%$ & 0 & $0.0 \%$ & 2 & $8.0 \%$ \\
\hline $5-6$ & 0 & $0.0 \%$ & 2 & $25.0 \%$ & 2 & $8.0 \%$ & 0 & $0.0 \%$ \\
\hline $7-8$ & 1. & $5.8 \%$ & 0 & $0.0 \%$ & 1 & $4.0 \%$ & 0 & $0.0 \%$ \\
\hline $9-10$ & 2 & $11.7 \%$ & 0 & $0.0 \%$ & 2 & $8.0 \%$ & 1 & $4.0 \%$ \\
\hline No answer & 2 & $11.7 \%$ & 1 & $12.5 \%$ & 3 & $12.0 \%$ & 1 & $4.0 \%$ \\
\hline Total & 17 & $99.7 \%^{*}$ & 8 & $100.0 \%$ & 25 & $100.0 \%$ & 25 & $100.0 \%$ \\
\hline
\end{tabular}

* Does not equal $100.0 \%$ due to rounding error. 
TABLE XXXVIII

ANNUAL GROSS INCOME

\begin{tabular}{|c|c|c|c|c|c|c|c|c|}
\hline \multirow{2}{*}{$\begin{array}{l}\text { Annual } \\
\text { Gross } \\
\text { Income }\end{array}$} & \multicolumn{2}{|c|}{ Program Males } & \multicolumn{2}{|c|}{ Program Females } & \multicolumn{2}{|c|}{ Sub-TotaI } & \multicolumn{2}{|c|}{ Non-Program Males } \\
\hline & $\begin{array}{l}\text { Freq.of } \\
\text { response }\end{array}$ & Percent & $\begin{array}{l}\text { Freq.of } \\
\text { response }\end{array}$ & Percetn & $\begin{array}{l}\text { Freq. of } \\
\text { response }\end{array}$ & Percent & $\begin{array}{l}\text { Freq. of } \\
\text { response }\end{array}$ & Percent \\
\hline $0-2999$ & 6 & $35.3 \%$ & \begin{tabular}{|l|}
3 \\
\end{tabular} & $37.5 \%$ & 9 & $36.0 \%$ & 7 & $28.0 \%$ \\
\hline $3000-3999$ & 1 & $5.8 \%$ & 0 & $0.0 \%$ & 1 & $4.0 \%$ & 1 & $4.0 \%$ \\
\hline $4000-4999$ & 2 & $11.7 \%$ & 0 & $0.0 \%$ & 2 & $8.0 \%$ & 2 & $8.0 \%$ \\
\hline $5000-5999$ & 1 & $5.8 \%$ & 0 & $0.0 \%$ & 1 & $4.0 \%$ & 3 & $12.0 \%$ \\
\hline $6000-6999$ & 1 & $5.8 \%$ & 0 & $0.0 \%$ & 1 & $4.0 \%$ & 1 & $4.0 \%$ \\
\hline $7000-7999$ & 1. & $5.8 \%$ & 1 & $12.5 \%$ & 2 & $8.0 \%$ & 1 & $4.0 \%$ \\
\hline $8000-8999$ & 1 & $5.8 \%$ & 0 & $0.0 \%$ & 1 & $4.0 \%$ & 0 & $0.0 \%$ \\
\hline $9000-9999$ & 1 & $5.8 \%$ & 1 & $12.5 \%$ & 2 & $8.0 \%$ & 2 & $8.0 \%$ \\
\hline $10000-14999$ & 1 & $5.8 \%$ & 1 & $12.5 \%$ & 2 & $8.0 \%$ & 3 & $12.0 \%$ \\
\hline 15000 \& over & 0 & $0.0 \%$ & 0 & $0.0 \%$ & 0 & $0.0 \%$ & 0 & $0.0 \%$ \\
\hline No answer & 2 & $11.7 \%$ & 2 & $25.0 \%$ & 4 & $16.0 \%$ & 3 & $12.0 \%$ \\
\hline I don't know & 0 & $0.0 \%$ & 0 & $0.0 \%$ & 0 & $0.0 \%$ & 2 & $8.0 \%$ \\
\hline Total & 17 & $99.3 \%$ & 8 & $100.0 \%$ & 25 & $100.0 \%$ & 25 & $100.0 \%$ \\
\hline
\end{tabular}

* Does not equal $100.0 \%$ due to rounding error. 
TABLE XXXIX

NUMBER OF TIMES THAT PATIENTS HAVE BEEN MARRIED

\begin{tabular}{|c|c|c|c|c|c|c|c|c|}
\hline \multirow{2}{*}{$\begin{array}{l}\text { Number of } \\
\text { Marriages }\end{array}$} & \multicolumn{2}{|c|}{ Program Males } & \multicolumn{2}{|c|}{ Program Females } & \multicolumn{2}{|c|}{ Sub-Tota1 } & \multicolumn{2}{|c|}{ Non-Program Males } \\
\hline & $\begin{array}{l}\text { Freq. of } \\
\text { response }\end{array}$ & Percent & $\begin{array}{l}\text { Freq.of } \\
\text { response }\end{array}$ & Percent & $\begin{array}{l}\text { Freq. of } \\
\text { response }\end{array}$ & Percent & $\begin{array}{l}\text { Freq. of } \\
\text { response }\end{array}$ & Percent \\
\hline 0 & 5 & $29.4 \%$ & 1 & $12.5 \%$ & 6 & $24.0 \%$ & 2 & $8.0 \%$ \\
\hline 1 & 6 & $35.3 \%$ & 2 & $25.0 \%$ & 8 & $32.0 \%$ & 12 & $48.0 \%$ \\
\hline 2 & 3 & $17.6 \%$ & 0 & $0.0 \%$ & 3 & $12.0 \%$ & 8 & $32.0 \%$ \\
\hline 3 & 1 & $5.8 \%$ & 2 & $25.0 \%$ & 3 & $12.0 \%$ & 3 & $12.0 \%$ \\
\hline 4 & 0 & $0.0 \%$ & 1 & $12.5 \%$ & 1 & $4.0 \%$ & 0 & $0.0 \%$ \\
\hline 5 & 1 & $5.8 \%$ & 0 & $0.0 \%$ & 1 & $4.0 \%$ & 0 & $0.0 \%$ \\
\hline No answer & 1 & $5.8 \%$ & 2 & $25.0 \%$ & 3 & $12.0 \%$ & 0 & $0.0 \%$ \\
\hline Total & 17 & $99.7 \%^{*}$ & 8 & $100.0 \%$ & 25 & $100.0 \%$ & 25 & $100.0 \%$ \\
\hline
\end{tabular}

* Does not equal $100.0 \%$ due to rounding error. 
TABLE XL

PATIENTS WHO HAVE CHILDREN

\begin{tabular}{|c|c|c|c|c|c|c|c|c|}
\hline \multirow[t]{2}{*}{ Children } & \multicolumn{2}{|c|}{ Program Males } & \multicolumn{2}{|c|}{ Program Females } & \multicolumn{2}{|c|}{ Sub-Total } & \multicolumn{2}{|c|}{ Non-Program Males } \\
\hline & $\begin{array}{l}\text { Freq. of } \\
\text { response }\end{array}$ & Percent & $\begin{array}{l}\text { Freq. of } \\
\text { response }\end{array}$ & Percent & $\begin{array}{l}\text { Freq.of } \\
\text { response }\end{array}$ & Percent & $\begin{array}{l}\text { req. of } \\
\text { fesponse }\end{array}$ & Percent \\
\hline Yes & 10 & $58.8 \%$ & 5 & $62.5 \%$ & 15 & $60.0 \%$ & 18 & $72.0 \%$ \\
\hline No & 7 & $41.2 \%$ & 3 & $37.5 \%$ & 10 & $40.0 \%$ & 7 & $28.0 \%$ \\
\hline Total & 17 & $100.0 \%$ & 8 & $100.0 \%$ & 25 & $100.0 \%$ & 25 & $100.0 \%$ \\
\hline
\end{tabular}


TABLE XLI

RELIGIOUS PREFERENCE

\begin{tabular}{|c|c|c|c|c|c|c|c|c|}
\hline \multirow[t]{2}{*}{ Religion } & \multicolumn{2}{|c|}{ Program Males } & \multicolumn{2}{|c|}{ Program Females } & \multicolumn{2}{|c|}{ Sub-Total } & \multicolumn{2}{|c|}{ Non-Program Males } \\
\hline & \begin{tabular}{|l|} 
Freq. of \\
response
\end{tabular} & Percent & $\begin{array}{l}\text { Freq. of } \\
\text { respons }\end{array}$ & Percent & $\begin{array}{l}\text { Freq. of } \\
\text { response }\end{array}$ & Percent & $\begin{array}{l}\text { Frea. of } \\
\text { response }\end{array}$ & Percent \\
\hline Protestant & 8 & $47.0 \%$ & 2 & $25.0 \%$ & 10 & $40.0 \%$ & 11 & $44.0 \%$ \\
\hline Jewish & 1 & $5.8 \%$ & 0 & $0.0 \%$ & 1 & $4.0 \%$ & 0 & $0.0 \%$ \\
\hline Catholic & 0 & $0.0 \%$ & 1 & $12.5 \%$ & 1 & $4.0 \%$ & 7 & $28.0 \%$ \\
\hline None & 5 & $29.4 \%$ & 4 & $50.0 \%$ & 9 & $36.0 \%$ & 7 & $28.0 \%$ \\
\hline Other & $2 *$ & $11.7 \%$ & $1^{* * *}$ & $12.5 \%$ & 3 & $12.0 \%$ & 0 & $0.0 \%$ \\
\hline No answer & 1 & $5.8 \%$ & 0 & $0.0 \%$ & 1 & $4.0 \%$ & 0 & $0.0 \%$ \\
\hline Total & 17 & $99.7 \% * *$ & 8 & $100.0 \%$ & 25 & $100.0 \%$ & 25 & $100.0 \%$ \\
\hline
\end{tabular}

* Latter Day Saints

** Does not equal $100.0 \%$ due to rounding error.

*** Mormon 
TABLE XLII

\section{CHURCH ATTENDANCE}

\begin{tabular}{|c|c|c|c|c|c|c|c|c|}
\hline \multirow{2}{*}{$\begin{array}{l}\text { Church } \\
\text { Attendance }\end{array}$} & \multicolumn{2}{|c|}{ Program Males } & \multicolumn{2}{|c|}{ Program Females } & \multicolumn{2}{|c|}{ Sub-Total } & \multicolumn{2}{|c|}{ Non-Program Males } \\
\hline & $\begin{array}{l}\text { Freq.of } \\
\text { respons }\end{array}$ & Percent & Freq.of & Percent & $\begin{array}{l}\text { Freq.of } \\
\text { response }\end{array}$ & Percent & $\begin{array}{l}\text { Freq.of } \\
\text { response }\end{array}$ & Percent \\
\hline $\begin{array}{l}\text { Once a week } \\
\text { or more }\end{array}$ & 1 & $5.8 \%$ & 2 & $25.0 \%$ & 3 & $12.0 \%$ & 2 & $8.0 \%$ \\
\hline $\begin{array}{l}\text { About once or } \\
\text { twice a mo. }\end{array}$ & 0 & $0.0 \%$ & 0 & $0.0 \%$ & 0 & $0.0 \%$ & 1 & $4.0 \%$ \\
\hline $\begin{array}{l}\text { A few times } \\
\text { during the yr. }\end{array}$ & 4 & $23.4 \%$ & 1 & $12.5 \%$ & 5 & $20.0 \%$ & 3 & $12.0 \%$ \\
\hline Only rarely & 8 & $47.0 \%$ & 2 & $25.0 \%$ & 10 & $40.0 \%$ & 11 & $44.0 \%$ \\
\hline Never & 4 & $23.4 \%$ & 3 & $37.5 \%$ & 7 & $28.0 \%$ & 8 & $32.0 \%$ \\
\hline Total & 17 & $99.6 \% *$ & 8 & $100.0 \%$ & 25 & $100.0 \%$ & 25 & $100.0 \%$ \\
\hline
\end{tabular}

* Does not equal $100.0 \%$ due to rounding error. 
TABLE XLIII

LIST OF HOBBIES AND RECREATIONAL ORGANIZATIONS

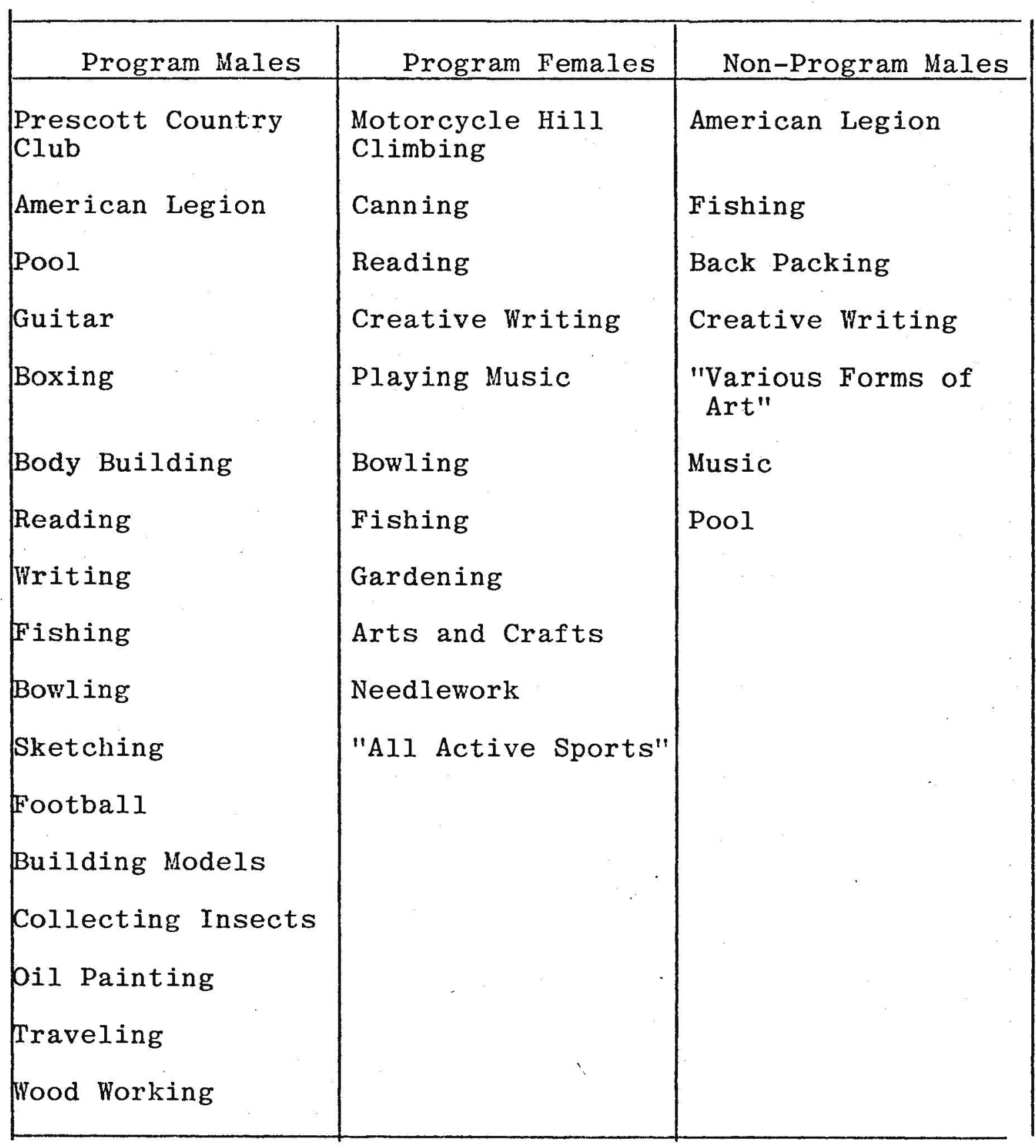


TABLE XLIV

LENGTH OF TIME SPENT IN OREGON

\begin{tabular}{|c|c|c|c|c|c|c|c|c|}
\hline \multirow[t]{2}{*}{ Years } & \multicolumn{2}{|c|}{ Program Males } & \multicolumn{2}{|c|}{ Program Females } & \multicolumn{2}{|c|}{ Sub-Total } & \multicolumn{2}{|c|}{ Non-Program Males } \\
\hline & $\begin{array}{l}\text { Freq. of } \\
\text { response }\end{array}$ & Percent & $\begin{array}{l}\text { Freq.of } \\
\text { response }\end{array}$ & Percent & $\begin{array}{l}\text { Freq. of } \\
\text { response }\end{array}$ & Percent & $\begin{array}{l}\text { Freq. of } \\
\text { response }\end{array}$ & Percent \\
\hline ' Less than 1 & 4 & $13.5 \%$ & 0 & $0.0 \%$ & 4 & $16.0 \%$ & 5 & $20.0 \%$ \\
\hline $1-5$ & 3 & $17.6 \%$ & 1 & $12.5 \%$ & 4 & $16.0 \%$ & 6 & $24.0 \%$ \\
\hline $5-10$ & 1 & $5.8 \%$ & 2 & $25.0 \%$ & 3 & $12.0 \%$ & 1 & $4.0 \%$ \\
\hline More than 10 & 3 & $17.6 \%$ & 2 & $25.0 \%$ & 5 & $20.0 \%$ & 5 & $20.0 \%$ \\
\hline All my Iife & 6 & $35.3 \%$ & 3 & $37.5 \%$ & 9 & $36.0 \%$ & 7 & $28.0 \%$ \\
\hline No answer & 0 & $0.0 \%$ & 0 & $0.0 \%$ & 0 & $0.0 \%$ & 1 & $4.0 \%$ \\
\hline Total & 17 & $99.8 \%^{*}$ & 8 & $100.0 \%$ & 25 & $100.0 \%$ & 25 & $100.0 \%$ \\
\hline
\end{tabular}

* Does not equal $100.0 \%$ due to rounding error. 
TABLE XLV

NUMBER OF MOVES IN THE PAST YEAR

\begin{tabular}{|c|c|c|c|c|c|c|c|c|}
\hline \multirow{2}{*}{$\begin{array}{l}\text { Number of } \\
\text { Moves }\end{array}$} & \multicolumn{2}{|c|}{ Program Males } & \multicolumn{2}{|c|}{ Program Females } & \multicolumn{2}{|c|}{ Sub-TotaI } & \multicolumn{2}{|c|}{ Non-Program Males } \\
\hline & $\begin{array}{l}\text { Freq. of } \\
\text { response }\end{array}$ & Percent & $\begin{array}{l}\text { Freq.of } \\
\text { response }\end{array}$ & Percent & $\begin{array}{l}\text { Freq. of } \\
\text { response }\end{array}$ & Percent & $\begin{array}{l}\text { Freq. of } \\
\text { response }\end{array}$ & Percent \\
\hline 0 & 6 & $35.3 \%$ & 1 & $12.5 \%$ & 7 & $28.0 \%$ & 5 & $20.0 \%$ \\
\hline $1-2$ & 3 & $17.6 \%$ & 3 & $37.5 \%$ & 6 & $24.0 \%$ & 8 & $32.0 \%$ \\
\hline $3-4$ & 1 & $5.8 \%$ & 2 & $25.0 \%$ & 2 & $8.0 \%$ & 3 & $12.0 \%$ \\
\hline $5-6$ & 0 & $0.0 \%$ & 2 & $25.0 \%$ & 2 & $8.0 \%$ & 3 & $12.0 \%$ \\
\hline over 6 & 1 & $5.8 \%$ & 0 & $0.0 \%$ & 1 & $4.0 \%$ & 1 & $4.0 \%$ \\
\hline Don't know' & 2 & $11.7 \%$ & 0 & $0.0 \%$ & 2 & $8.0 \%$ & 3 & $12.0 \%$ \\
\hline No answer & 4 & $23.5 \%$ & 0 & $0.0 \%$ & 4 & $16.0 \%$ & 1 & $4.0 \%$ \\
\hline Total & 17 & $99.7 \%^{*}$ & 8 & $100.0 \%$ & 25 & $100.0 \%$ & 25 & $100.0 \%$ \\
\hline
\end{tabular}

* Does not equal $100.0 \%$ due to rounding error. 
PATIENTS WHO WERE IN A DETOXIFICATION CENTER BEFORE ENTERING THE HOSPITAL

\begin{tabular}{|c|c|c|c|c|c|c|c|c|}
\hline \multirow{2}{*}{$\begin{array}{c}\text { In } \\
\text { Detox }\end{array}$} & \multicolumn{2}{|c|}{ Program Males } & \multicolumn{2}{|c|}{ Program Females } & \multicolumn{2}{|c|}{ Sub-Total } & \multicolumn{2}{|c|}{ Non-Program Males } \\
\hline & $\begin{array}{l}\text { Freq. of } \\
\text { response }\end{array}$ & Percent & $\begin{array}{l}\text { Preq. of } \\
\text { cesponse }\end{array}$ & Percent & $\begin{array}{l}\text { Freq. of } \\
\text { response }\end{array}$ & Percent & $\begin{array}{l}\text { Freq. of } \\
\text { cesponse }\end{array}$ & Percent \\
\hline Yes & 6 & $35.3 \%$ & 2 & $25.0 \%$ & 8 & $32.0 \%$ & 8 & $32.0 \%$ \\
\hline No & 11 & $64.7 \%$ & 6 & $75.0 \%$ & 17 & $68.0 \%$ & 16 & $64.0 \%$ \\
\hline No answer & 0 & $0.0 \%$ & 0 & $0.0 \%$ & 0 & $0.0 \%$ & 1 & $4.0 \%$ \\
\hline Total & 17 & $100.0 \%$ & 8 & $100.0 \%$ & 25 & $100.0 \%$ & 25 & $100.0 \%$ \\
\hline
\end{tabular}


TABLE XLVII

NUMBER OF CLOSE FRIENDS IN THE COMMUNITY

\begin{tabular}{|l|r|r|r|r|r|r|r|r|}
\hline \multirow{2}{*}{$\begin{array}{l}\text { Number } \\
\text { of } \\
\text { Friends }\end{array}$} & \multicolumn{2}{|c|}{\begin{tabular}{c} 
Program Males \\
\cline { 2 - 8 }
\end{tabular}} & \multicolumn{2}{c|}{$\begin{array}{c}\text { Program Females } \\
\text { response }\end{array}$} & \multicolumn{2}{c|}{ Sub-Total } & \multicolumn{2}{c|}{ Non-Progam Males } \\
\hline 6 or more & 2 & $11.7 \%$ & 2 & $25.0 \%$ & 4 & $16.0 \%$ & 4 & $16.0 \%$ \\
$3-5$ & 5 & $29.4 \%$ & 0 & $0.0 \%$ & 5 & $20.0 \%$ & 6 & $24.0 \%$ \\
$1-2$ & 4 & $23.5 \%$ & 2 & $25.0 \%$ & 6 & $24.0 \%$ & 7 & $28.0 \%$ \\
None & 6 & $35.3 \%$ & 4 & $50.0 \%$ & 10 & $40.0 \%$ & 8 & $32.0 \%$ \\
\hline Total & 17 & $99.9 \% *$ & 8 & $100.0 \%$ & 25 & $100.0 \%$ & 25 & $100.0 \%$ \\
\hline
\end{tabular}

* Does not equal $100.0 \%$ due to rounding error. 
TABLE XLVIII

NUMBER OF ARRESTS FOR INTOXICATION REEATED CHARGES IN THE PAST YEAR

\begin{tabular}{|c|c|c|c|c|c|c|c|c|}
\hline \multirow{2}{*}{$\begin{array}{l}\text { Number of } \\
\text { Arrests }\end{array}$} & \multicolumn{2}{|c|}{ Program Males } & \multicolumn{2}{|c|}{ Program Females } & \multicolumn{2}{|c|}{ Sub-Total } & \multicolumn{2}{|c|}{ Non-Program Males } \\
\hline & $\begin{array}{l}\text { Freq. of } \\
\text { response }\end{array}$ & Percent & $\begin{array}{l}\text { Freq.of } \\
\text { respnse }\end{array}$ & Percent & $\begin{array}{l}\text { Freq.of } \\
\text { response }\end{array}$ & Percent & $\begin{array}{l}\text { Freq.of } \\
\text { response }\end{array}$ & Percent \\
\hline Never & 12 & $70.5 \%$ & 4 & $50.0 \%$ & 16 & $64.0 \%$ & 14 & $56.0 \%$ \\
\hline 1-2 times & 3 & $17.6 \%$ & 1 & $12.5 \%$ & 4 & $16.0 \%$ & 7 & $28.0 \%$ \\
\hline 3-5 times & 1 & $5.8 \%$ & 2 & $25.0 \%$ & 3 & $12.0 \%$ & 2 & $8.0 \%$ \\
\hline 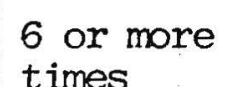 & 1 & $5.8 \%$ & 0 & $0.0 \%$ & 1 & $4.0 \%$ & 2 & $8.0 \%$ \\
\hline No answer & 0 & $0.0 \%$ & 1 & $12.5 \%$ & 1 & $4.0 \%$ & 2 & $0.0 \%$ \\
\hline Total & 17 & $99.7 \%$ & 8 & $100.0 \%$ & 25 & $100.0 \%$ & 25 & $100.0 \%$ \\
\hline
\end{tabular}

* Does not equal $100.0 \%$ due to rounding error. 
NUMBER OF ARRESTS FOR ANYTHING ELSE IN THE PAST YEAR (OTHER THAN INTOXICATION RELATED CHARGES)

\begin{tabular}{|c|c|c|c|c|c|c|c|c|}
\hline \multirow{2}{*}{$\begin{array}{l}\text { Number } \\
\text { of } \\
\text { Arrests }\end{array}$} & \multicolumn{2}{|c|}{ Program Males } & \multicolumn{2}{|c|}{ Program Females } & \multicolumn{2}{|c|}{ Sub-Total } & \multicolumn{2}{|c|}{ Non-Program Males } \\
\hline & $\begin{array}{l}\text { Freq of } \\
\text { response }\end{array}$ & Percent & $\begin{array}{l}\text { Freq.of } \\
\text { response }\end{array}$ & Percent & $\begin{array}{l}\text { Freq of } \\
\text { response }\end{array}$ & Percent & $\begin{array}{l}\text { Freq.of } \\
\text { response }\end{array}$ & Percent \\
\hline never & 14 & $82.3 \%$ & 5 & $62.5 \%$ & 19 & $76.0 \%$ & 18 & $72.0 \%$ \\
\hline 1-2 times & 2 & $11.7 \%$ & 2 & $25.0 \%$ & 4 & $16.0 \%$ & 6 & $24.0 \%$ \\
\hline 3-5 times & 0 & $0.0 \%$ & 2 & $0.0 \%$ & 0 & $0.0 \%$ & 1 & $4.0 \%$ \\
\hline 6 or more & 1 & $5.8 \%$ & 0 & $0.0 \%$ & 1 & $4.0 \%$ & 0 & $0.0 \%$ \\
\hline No answer & 0 & $0.0 \%$ & 1 & $12.5 \%$ & 1 & $4.0 \%$ & 0 & $0.0 \%$ \\
\hline Total & 17 & $99.8 \%^{*}$ & 8 & $100.0 \%$ & 25 & $100.0 \%$ & 25 & $100.0 \%$ \\
\hline
\end{tabular}

* Does not equal $100.0 \%$ due to rounding error. 
TABLE L

\section{CURRENT CHARGES}

\begin{tabular}{|c|c|c|c|c|c|c|c|c|}
\hline \multirow{2}{*}{$\begin{array}{l}\text { Current } \\
\text { Charges }\end{array}$} & \multicolumn{2}{|c|}{ Program Males } & \multicolumn{2}{|c|}{ Program Females } & \multicolumn{2}{|c|}{ Sub-Total } & \multicolumn{2}{|c|}{ Non-Program Males } \\
\hline & $\begin{array}{l}\text { Freq. of } \\
\text { response }\end{array}$ & Percent & $\begin{array}{l}\text { Freq.of } \\
\text { response }\end{array}$ & Percent & $\begin{array}{l}\text { Freq.of } \\
\text { response }\end{array}$ & Percent & $\begin{array}{l}\text { Freq.of } \\
\text { fesponse }\end{array}$ & Percent \\
\hline Yes & 0 & $0.0 \%$ & 1 & $12.5 \%$ & 1 & $4.0 \%$ & 3 & $12.0 \%$ \\
\hline No & 16 & $94.1 \%$ & 6 & $75.0 \%$ & 22 & $88.0 \%$ & 19 & $76.0 \%$ \\
\hline No answer & 1 & $5.8 \%$ & 1 & $12.5 \%$ & 2 & $8.0 \%$ & 3 & $12.0 \%$ \\
\hline Total & 17 & $99.9 \%^{*}$ & 8 & $100.0 \%$ & 25 & $100.0 \%$ & 15 & $100.0 \%$ \\
\hline
\end{tabular}

* Does not equal $100.0 \%$ due to rounding error. 
TABLE LI

AGE WHEN PATIENTS HAD THEIR FIRST DRINK

\begin{tabular}{|c|c|c|c|c|c|c|c|c|}
\hline \multirow[t]{2}{*}{ Age } & \multicolumn{2}{|c|}{ Program Males } & \multicolumn{2}{|c|}{ Program Females } & \multicolumn{2}{|c|}{ Sub-Total } & \multicolumn{2}{|c|}{ Non-Program Males } \\
\hline & $\begin{array}{l}\text { Freq. of } \\
\text { response }\end{array}$ & Percent & $\begin{array}{l}\text { Freq.of } \\
\text { response }\end{array}$ & Percent & $\begin{array}{l}\text { Freq.of } \\
\text { response }\end{array}$ & Percent & $\begin{array}{l}\text { Freq. of } \\
\text { response }\end{array}$ & Percent \\
\hline $5-8$ & 3 & $17.6 \%$ & 0 & $0.0 \%$ & 3 & $12.0 \%$ & 4 & $16.0 \%$ \\
\hline $9-12$ & 2 & $11.7 \%$ & 1 & $12.5 \%$ & 3 & $12.0 \%$ & 5 & $20.0 \%$ \\
\hline $13-16$ & 8 & $47.0 \%$ & 4 & $50.0 \%$ & 12 & $48.0 \%$ & 11 & $44.0 \%$ \\
\hline $17-19$ & 3 & $5.8 \%$ & 1 & $12.5 \%$ & 4 & $16.0 \%$ & 2 & $8.0 \%$ \\
\hline No answer & 1. & $5.8 \%$ & 2 & $25.0 \%$ & 3 & $12.0 \%$ & 3 & $12.0 \%$ \\
\hline Total & 17 & $99.7 \%^{*}$ & 8 & $100.0 \%$ & 25 & $100.0 \%$ & 25 & $100.0 \%$ \\
\hline
\end{tabular}

* Does not equal $100.0 \%$ due to rounding error. 
TABLE LII

PERSONS WITH WHOM PATIENTS HAD THEIR FIRST DRINKING EXPERIENCE

\begin{tabular}{|c|c|c|c|c|c|c|c|c|}
\hline \multirow[t]{2}{*}{ Persons } & \multicolumn{2}{|c|}{ Program Males } & \multicolumn{2}{|c|}{ Program Females } & \multicolumn{2}{|c|}{ Sub-Tota1 } & \multicolumn{2}{|c|}{ Non-Program Males } \\
\hline & $\begin{array}{l}\text { Freq. of } \\
\text { response }\end{array}$ & Percent & $\begin{array}{l}\text { Freq. of } \\
\text { response }\end{array}$ & Percent & $\begin{array}{l}\text { Freq. of } \\
\text { cespense }\end{array}$ & Percent & $\begin{array}{l}\text { Freq. of } \\
\text { cesponse }\end{array}$ & Percent \\
\hline Relatives & 5 & $29.4 \%$ & 1 & $12.5 \%$ & 6 & $24.0 \%$ & 6 & $24.0 \%$ \\
\hline Friends & 6 & $35.3 \%$ & 4 & $50.0 \%$ & 10 & $40.0 \%$ & 10 & $40.0 \%$ \\
\hline Alone & 2 & $11.7 \%$ & 0 & $0.0 \%$ & 2 & $8.0 \%$ & 2 & $8.0 \%$ \\
\hline No answer & 4 & $23.5 \%$ & 3 & $37.5 \%$ & 7 & $28.0 \%$ & 7 & $28.0 \%$ \\
\hline Total & 17 & $99.9 \%^{*}$ & 8 & $100.0 \%$ & 25 & $100.0 \%$ & 25 & $100.0 \%$ \\
\hline
\end{tabular}

* Does not equal $100.0 \%$ due to rounding error. 
TABLE LIII

PLACES WHERE PATIENTS USUALLY DRANK BEFORE ENTERING THE HOSPITAL

\begin{tabular}{|c|c|c|c|c|c|c|c|c|}
\hline \multirow[t]{2}{*}{ Places } & \multicolumn{2}{|c|}{ Program Males } & \multicolumn{2}{|c|}{ Program Females } & \multicolumn{2}{|c|}{ Sub-Total } & \multicolumn{2}{|c|}{ Non-Program Males } \\
\hline & $\begin{array}{l}\text { Freq. of } \\
\text { response }\end{array}$ & Percent & $\begin{array}{l}\text { Freq.of } \\
\text { response }\end{array}$ & Percent & $\begin{array}{l}\text { Freq. of } \\
\text { response }\end{array}$ & Percent & $\begin{array}{l}\text { Freq. of } \\
\text { response }\end{array}$ & Percent \\
\hline At home & 1 & $5,8 \%$ & 3 & $37.5 \%$ & 4 & $16.0 \%$ & 6 & $24.0 \%$ \\
\hline In a bar & 4 & $23.5 \%$ & 0 & $0.0 \%$ & 4 & $16.0 \&$ & 2 & $3.0 \%$ \\
\hline $\begin{array}{l}\text { In several } \\
\text { places }\end{array}$ & 12 & $70.6 \%$ & 4 & $50.0 \%$ & 16 & $64.0 \%$ & 16 & $64.0 \%$ \\
\hline No answer & 0 & $0.0 \%$ & 1 & $12.5 \%$ & 1 & $4.0 \%$ & 1 & $4.0 \%$ \\
\hline Total & 17 & $99.9 \%^{*}$ & 8 & $100.0 \%$ & 25 & $100.0 \%$ & 25 & $100.0 \%$ \\
\hline
\end{tabular}

* Does: not equal $100.0 \%$ due to rounding error. 
TABLE LIV

AMOUNT OF WINE CONSUMED DAILY

\begin{tabular}{|c|c|c|c|c|c|c|c|c|}
\hline \multirow{2}{*}{$\begin{array}{l}\text { Amount } \\
\text { of } \\
\text { Wine }\end{array}$} & \multicolumn{2}{|c|}{ Program Males } & \multicolumn{2}{|c|}{ Program Females } & \multicolumn{2}{|c|}{ Sub-Tetal } & \multicolumn{2}{|c|}{ Non-Program Males } \\
\hline & $\begin{array}{l}\text { Freq. of } \\
\text { response }\end{array}$ & Percent & $\begin{array}{l}\text { Freq.of } \\
\text { response }\end{array}$ & Percent & $\begin{array}{l}\text { Freq.of } \\
\text { resonse }\end{array}$ & Perceht & $\begin{array}{l}\text { Freq. of } \\
\text { response }\end{array}$ & Percent \\
\hline None & 2 & $11.7 \%$ & 1 & $12.5 \%$ & 3 & $12.0 \%$ & 5 & $20.0 \%$ \\
\hline$\frac{1}{2}$ qt.or less & 3 & $17.6 \%$ & 1 & $12.5 \%$ & 4 & $16.0 \%$ & 3 & $12.0 \%$ \\
\hline $1 \mathrm{qt}$. & 2 & $11.7 \%$ & 1 & $12.5 \%$ & 3 & $12.0 \%$ & 4 & $16.0 \%$ \\
\hline 2 qts. & 2 & $11.7 \%$ & 1 & $12.5 \%$ & 3 & $12.0 \%$ & 4 & $16.0 \%$ \\
\hline More than 2 & 8 & $47.0 \%$ & 2 & $25.0 \%$ & 10 & $40.0 \%$ & 9 & $36.0 \%$ \\
\hline No answer & 0 & $0.0 \%$ & 2 & $25.0 \%$ & 2 & $8.0 \%$ & 0 & $0.0 \%$ \\
\hline Total & 17 & $99.7 \%^{*}$ & 8 & $100.0 \%$ & 25 & $100.0 \%$ & 25 & $100.0 \%$ \\
\hline
\end{tabular}

* Does no equal $100.0 \%$ due to rounding error 
TABLE LV

AMOUNT OF BEER CONSUMED DAILY

\begin{tabular}{|c|c|c|c|c|c|c|c|c|}
\hline \multirow{2}{*}{$\begin{array}{l}\text { Amount of } \\
\text { Beer }\end{array}$} & \multicolumn{2}{|c|}{ Program Males } & \multicolumn{2}{|c|}{ Program Females } & \multicolumn{2}{|c|}{ Sub-Total } & \multicolumn{2}{|c|}{ Non-Program Males } \\
\hline & $\begin{array}{l}\text { Freq.of } \\
\text { response }\end{array}$ & Percent & $\begin{array}{l}\text { Freq.of } \\
\text { response }\end{array}$ & Percent & $\begin{array}{l}\text { Freq. of } \\
\text { response }\end{array}$ & Percent & $\begin{array}{l}\text { Freq.of } \\
\text { response }\end{array}$ & Percent \\
\hline None & 2 & $11 / 7 \%$ & 1 & $12.5 \%$ & 3 & $12.0 \%$ & 5 & $20.0 \%$ \\
\hline $\begin{array}{l}\text { Less than } 1 \text { qt. } \\
\text { ( } 1-3 \text { cans) }\end{array}$ & 3 & $17.6 \%$ & 1 & $12.5 \%$ & 4 & $16.0 \%$ & 3 & $12.0 \%$ \\
\hline $\begin{array}{l}\text { Up to } 2 \text { qts. } \\
\text { (4-6 cans) }\end{array}$ & 2 & $11.7 \%$ & 1 & $12.5 \%$ & 3 & $12.0 \%$ & 4 & $16.0 \%$ \\
\hline $\begin{array}{l}\text { Up to } 3 \text { qts. } \\
\text { ( } 7-10 \text { cans) }\end{array}$ & 2 & $11.7 \%$ & 1 & $12.5 \%$ & 3 & $12.0 \%$ & 4 & $16.0 \%$ \\
\hline More than 3 qts. & 8 & $47.0 \%$ & 2 & $25.0 \%$ & 10 & $40.0 \%$ & 9 & $36.0 \%$ \\
\hline No answer & 0 & $0.0 \%$ & 2 & $25.0 \%$ & 2 & $8.0 \%$ & 0 & $0.0 \%$ \\
\hline Total & 17 & $99.7 \%^{*}$ & 8 & $100.0 \%$ & 25 & $100.0 \%$ & 25 & $100.0 \%$ \\
\hline
\end{tabular}

* Does not equal $100.0 \%$ due to rounding error. 
TABLE LVI

AMOUNT OF HARD LIQUOR CONSUMED DAILY

\begin{tabular}{|c|c|c|c|c|c|c|c|c|}
\hline \multirow{2}{*}{$\begin{array}{l}\text { Amount of } \\
\text { hard } \\
\text { Liquor }\end{array}$} & \multicolumn{2}{|c|}{ Program Males } & \multicolumn{2}{|c|}{ Program Females } & \multicolumn{2}{|c|}{ Sub-Total } & \multicolumn{2}{|c|}{ Non-Program Males } \\
\hline & $\begin{array}{l}\text { Freq.of } \\
\text { response }\end{array}$ & Percent & $\begin{array}{l}\text { Freq.of } \\
\text { response }\end{array}$ & Percent & $\begin{array}{l}\text { Freq. of } \\
\text { response }\end{array}$ & Percent & $\begin{array}{l}\text { Freq.of } \\
\text { response }\end{array}$ & Percent \\
\hline None & 10 & $58.8 \%$ & 1 & $12.5 \%$ & 11 & $44.0 \%$ & 7 & $28.0 \%$ \\
\hline$\frac{1}{2}$ pint & 1 & $5.8 \%$ & 1 & $12.5 \%$ & 2 & $8.0 \%$ & 0 & $0.0 \%$ \\
\hline Pint & 2 & $11.7 \%$ & 1 & $12.5 \%$ & 3 & $12.0 \%$ & 7 & $28.0 \%$ \\
\hline Quart. & 0 & $0.0 \%$ & 2 & $25.0 \%$ & 2 & $8.0 \%$ & 5 & $20.0 \%$ \\
\hline More than 1 qt & 4 & $23.5 \%$ & 1 & $12.5 \%$ & 5 & $20.0 \%$ & 5 & $20.0 \%$ \\
\hline No answer & 0 & $0.0 \%$ & 2 & $25.0 \%$ & 2 & $8.0 \%$ & 1 & $4.0 \%$ \\
\hline Total & 17 & $99.8 \% *$ & 8 & $100.0 \%$ & 25 & $100.0 \%$ & 25 & $100.0 \%$ \\
\hline
\end{tabular}

* Doe not equal $100.0 \%$ due to rounding error. 
TABLE LVII

LOSS OF EMPLOYMENT DUE TO DRINKING

\begin{tabular}{|c|c|c|c|c|c|c|c|c|}
\hline \multirow{2}{*}{$\begin{array}{l}\text { Loss of } \\
\text { Employment }\end{array}$} & \multicolumn{2}{|c|}{ Program Male } & \multicolumn{2}{|c|}{ Program Females } & \multicolumn{2}{|c|}{ Sub-Tota 1} & \multicolumn{2}{|c|}{ Non-Program Males } \\
\hline & $\begin{array}{l}\text { Freq. of } \\
\text { response }\end{array}$ & Percent & $\begin{array}{l}\text { Freq.of } \\
\text { response }\end{array}$ & Percent & $\begin{array}{l}\text { Freq.of } \\
\text { response }\end{array}$ & Percent & $\begin{array}{l}\text { Freq.of } \\
\text { response }\end{array}$ & Percent \\
\hline Yes & 13 & $76.5 \%$ & 3 & $37.5 \%$ & 16 & $64.0 \%$ & 19 & $76.0 \%$ \\
\hline No & 3 & $17.6 \%$ & 4 & $50.0 \%$ & 7 & $28.0 \%$ & 3 & $12.0 \%$ \\
\hline No answer & 1 & $5.8 \%$ & 1 & $12.5 \%$ & 2 & $8.0 \%$ & 3 & $2.0 \%$ \\
\hline Total & 17 & $99.9 \%^{*}$ & 8 & $100.0 \%$ & 25 & $100.0 \%$ & 25 & $100.0 \%$ \\
\hline
\end{tabular}

* Does not equal $100.0 \%$ due to rounding error. 
TABLE LVIII

DRINKING FOR THE PURPOSE OF RELAXATION

\begin{tabular}{|c|c|c|c|c|c|c|c|c|}
\hline \multirow{2}{*}{$\begin{array}{l}\text { Level of } \\
\text { Importance } \\
\end{array}$} & \multicolumn{2}{|c|}{ Program Males } & \multicolumn{2}{|c|}{ Program Females } & \multicolumn{2}{|c|}{ Sub-TotaI } & \multicolumn{2}{|c|}{ Non-Program Males } \\
\hline & $\begin{array}{l}\text { Freq.of } \\
\text { response }\end{array}$ & Percent & $\begin{array}{l}\text { Freq.of } \\
\text { response }\end{array}$ & Percent & $\begin{array}{l}\text { Freq.of } \\
\text { response }\end{array}$ & Percent & $\begin{array}{l}\text { Freq.of } \\
\text { response }\end{array}$ & Percent \\
\hline Very & 5 & $29.4 \%$ & 5 & $62.5 \%$ & 10 & $40.0 \%$ & 12 & $48.0 \%$ \\
\hline Fairly & 7 & $41.1 \%$ & 1 & $12.5 \%$ & 8 & $32.0 \%$ & 9 & $36.0 \%$ \\
\hline Not at alI & 2 & $11.7 \%$ & 0 & $0.0 \%$ & 2 & $8.0 \%$ & 2 & $8.0 \%$ \\
\hline \multirow[t]{2}{*}{ No answer } & 3 & $17.6 \%$ & 2 & $25.0 \%$ & 5 & $20.0 \%$ & 2 & $8.0 \%$ \\
\hline & 17 & $99.8 \%^{*}$ & 8 & $100.0 \%$ & 25 & $100.0 \%$ & 25 & $100.0 \%$ \\
\hline
\end{tabular}

* Does not equal $100.0 \%$ due to rounding error. 


\section{TABLE LIX}

DRINKING IN ORDER TO BE SOCIABLE

\begin{tabular}{|c|c|c|c|c|c|c|c|c|}
\hline \multirow{2}{*}{$\begin{array}{l}\text { Level of } \\
\text { Importance }\end{array}$} & \multicolumn{2}{|c|}{ Program Males } & \multicolumn{2}{|c|}{ Program Females } & \multicolumn{2}{|c|}{ Sub-Total } & \multicolumn{2}{|c|}{ Non-Program Males } \\
\hline & $\begin{array}{c}\text { Freq. of } \\
\text { response }\end{array}$ & Percent & \begin{tabular}{r|} 
Freq.of \\
response
\end{tabular} & Percent & $\begin{array}{l}\text { Freq. of } \\
\text { response }\end{array}$ & Percent & $\begin{array}{l}\text { Freq. of } \\
\text { response }\end{array}$ & Percent \\
\hline Very & 4 & $23.5 \%$ & 1 & $12.5 \%$ & 5 & $20.0 \%$ & 5 & $20.0 \%$ \\
\hline Fairly & 4 & $23.5 \%$ & 3 & $37.5 \%$ & 7 & $28.0 \%$ & 10 & $40.0 \%$ \\
\hline Not at all & 6 & $35.3 \%$ & 2 & $25.0 \%$ & 8 & $32.0 \%$ & 5 & $20.0 \%$ \\
\hline No answer & 3 & $17.6 \%$ & 2 & $25.0 \%$ & 5 & $20.0 \%$ & 5 & $20.0 \%$ \\
\hline Total & 17 & $99.9 \% *$ & 8 & $100.0 \%$ & 25 & $100.0 \%$ & 25 & $100.0 \%$ \\
\hline
\end{tabular}

* Does not equal $100.0 \%$ due to rounding error. 


\section{TABLE LX}

DRINKING IN ORDER TO FORGET UNPLEASANT THOUGHTS

\begin{tabular}{|c|c|c|c|c|c|c|c|c|}
\hline \multirow{2}{*}{$\begin{array}{l}\text { Level of } \\
\text { Importance }\end{array}$} & \multicolumn{2}{|c|}{ program Males } & \multicolumn{2}{|c|}{ Program Females } & \multicolumn{2}{|c|}{ Sub-Tota1 } & \multicolumn{2}{|c|}{ Non-Program Males } \\
\hline & $\begin{array}{l}\text { Freq. of } \\
\text { response }\end{array}$ & Percent & $\begin{array}{l}\text { req. of } \\
\text { response }\end{array}$ & Percent & $\begin{array}{l}\text { Freq. of } \\
\text { response }\end{array}$ & Percent & $\begin{array}{l}\text { freq. of } \\
\text { response }\end{array}$ & Percent \\
\hline$\overline{\text { Very }}$ & 9 & $52.9 \%$ & 5 & $62.5 \%$ & 14 & $56.0 \%$ & 16 & $64.0 \%$ \\
\hline Fairly & 2 & $11.7 \%$ & 0 & $0.0 \%$ & 2 & $8.0 \%$ & 6 & $24.0 \%$ \\
\hline Not at all & 3 & $17.6 \%$ & 0 & $0.0 \%$ & 3 & $12.0 \%$ & 0 & $0.0 \%$ \\
\hline No answer & 3 & $17.6 \%$ & 3 & $37.5 \%$ & 6 & $24.0 \%$ & 3 & $12.0 \%$ \\
\hline Total & 17 & $99.8 \%^{*}$ & 8 & $100.0 \%$ & 25 & $100.0 \%$ & 25 & $100.0 \%$ \\
\hline
\end{tabular}

* Does not equal $100.0 \%$ due to rounding error. 
TABLE LXI

DRINKING IN ORDER TO FEEL LESS DEPRESSED AND ANXIOUS

\begin{tabular}{|c|c|c|c|c|c|c|c|c|}
\hline \multirow{2}{*}{$\begin{array}{l}\text { Order of } \\
\text { Importance }\end{array}$} & \multicolumn{2}{|c|}{ Program Males } & \multicolumn{2}{|c|}{ Program Females } & \multicolumn{2}{|c|}{ Sub-Total } & \multicolumn{2}{|c|}{ Non-Program Males } \\
\hline & $\begin{array}{l}\text { Freq. of } \\
\text { responce }\end{array}$ & Percent & $\begin{array}{l}\text { Freq. of } \\
\text { cesponse }\end{array}$ & Percent & $\begin{array}{l}\text { Freq.of } \\
\text { response }\end{array}$ & Percent & $\begin{array}{l}\text { req.of } \\
\text { response }\end{array}$ & Percent \\
\hline Very & 5 & $29.4 \%$ & 7 & $87.5 \%$ & 12 & $48.0 \%$ & 12 & $48.0 \%$ \\
\hline Fairly & 7 & $41.1 \%$ & 0 & $0.0 \%$ & 7 & $28.0 \%$ & 8 & $32.0 \%$ \\
\hline Not at a11 & 1 & $5.8 \%$ & 0 & $0.0 \%$ & 1 & $4.0 \%$ & 2 & $8.0 \%$ \\
\hline No answer & 4 & $23.5 \%$ & 1 & $12.5 \%$ & 5 & $20.0 \%$ & 3 & $12.0 \%$ \\
\hline TotaI & 17 & $99.8 \%^{*}$ & 8 & $100.0 \%$ & 25 & $100.0 \%$ & 25 & $100.0 \%$ \\
\hline
\end{tabular}

* Does not equal $100.0 \%$ due to rounding error. 
TABLE LXXI

DRINKING TO RELIEVE ANGRY FEELINGS

\begin{tabular}{|c|c|c|c|c|c|c|c|c|}
\hline \multirow{2}{*}{$\begin{array}{l}\text { Order of } \\
\text { Importance }\end{array}$} & \multicolumn{2}{|c|}{ Program Males } & \multicolumn{2}{|c|}{ Program Females } & \multicolumn{2}{|c|}{ Sub-Total } & \multicolumn{2}{|c|}{ Non-Program Males } \\
\hline & \begin{tabular}{|l|} 
Freq. of \\
response
\end{tabular} & Percent & $\begin{array}{l}\text { Freq. of } \\
\text { eesponse }\end{array}$ & Percent & $\begin{array}{l}\text { req.of } \\
\text { response }\end{array}$ & Percent & $\begin{array}{l}\text { Freq. of } \\
\text { response }\end{array}$ & Percent \\
\hline Very & 4 & $23.5 \%$ & 3 & $37.5 \%$ & 7 & $28.0 \%$ & 4 & $16.0 \%$ \\
\hline Fairly & 4 & $23.5 \%$ & 0 & $0.0 \%$ & 4 & $16.0 \%$ & 8 & $32.0 \%$ \\
\hline Not at a11 & 4 & $23.5 \%$ & 2 & $25.0 \%$ & 6 & $24.0 \%$ & 8 & $32.0 \%$ \\
\hline No answer & 5 & $29.4 \%$ & 3 & $37.5 \%$ & 8 & $32.0 \%$ & 5 & $20.0 \%$ \\
\hline Total & 17 & $99.9 \%^{*}$ & 8 & $100.0 \%$ & 25 & $100.0 \%$ & 25 & $100.0 \%$ \\
\hline
\end{tabular}

* Does not equal $100.0 \%$ due to rounding error. 
TABLE LXIII

DRINKING IN ORDER TO RELATE FEELINGS AND THOUGHTS TO THE OPPOSITE SEX

\begin{tabular}{|c|c|c|c|c|c|c|c|c|}
\hline \multirow{2}{*}{$\begin{array}{l}\text { Level of } \\
\text { Importance }\end{array}$} & \multicolumn{2}{|c|}{ Program Males } & \multicolumn{2}{|c|}{ Program Females } & \multicolumn{2}{|c|}{ Sub-Tqtal } & \multicolumn{2}{|c|}{ Non-Program Males } \\
\hline & $\begin{array}{l}\text { Freq. of } \\
\text { response }\end{array}$ & Percent & $\begin{array}{l}\text { Freq. of } \\
\text { response }\end{array}$ & Percent & $\begin{array}{l}\text { Freq. of } \\
\text { response }\end{array}$ & Percent & $\begin{array}{l}\text { Freq. of } \\
\text { response }\end{array}$ & Percent \\
\hline Very & 3 & $17.6 \%$ & 2 & $25.0 \%$ & 5 & $20.0 \%$ & 5 & $20.0 \%$ \\
\hline Fairly & 4 & $23.5 \%$ & 0 & $0.0 \%$ & 4 & $16.0 \%$ & 5 & $20.0 \%$ \\
\hline Not at all & 6 & $35.3 \%$ & 1 & $12.5 \%$ & 7 & $28.0 \%$ & 8 & $32.0 \%$ \\
\hline No answer & 4 & $23.5 \%$ & 5 & $62.5 \%$ & 9 & $36.0 \%$ & 7 & $28.0 \%$ \\
\hline Total & 17 & $99.9 \%^{*}$ & 8 & $100.0 \%$ & 25 & $100.0 \%$ & 25 & $100.0 \%$ \\
\hline
\end{tabular}

* Does not equal $100.0 \%$ due to rounding error. 
TABLE LXIV

DRINKING IN ORDER TO CHANGE MOOD

\begin{tabular}{|c|c|c|c|c|c|c|c|c|}
\hline \multirow{2}{*}{$\begin{array}{l}\text { Order of } \\
\text { Importance }\end{array}$} & \multicolumn{2}{|c|}{ Program Males } & \multicolumn{2}{|c|}{ Program Females } & \multicolumn{2}{|c|}{ Sub-TotaI } & \multicolumn{2}{|c|}{ Non-Program Males } \\
\hline & $\begin{array}{l}\text { Freq. of } \\
\text { response }\end{array}$ & Percent & $\begin{array}{l}\text { Freq.of } \\
\text { esponse }\end{array}$ & Percent & $\begin{array}{l}\text { Freq. of } \\
\text { response }\end{array}$ & Percent & $\begin{array}{l}\text { Freq.of } \\
\text { fesponse }\end{array}$ & Percent \\
\hline Very & 5 & $29.4 \%$ & 7 & $87.5 \%$ & 12 & $48.0 \%$ & 10 & $40.0 \%$ \\
\hline Fairly & 4 & $23.5 \%$ & 0 & $0.0 \%$ & 4 & $16.0 \%$ & 8 & $32.0 \%$ \\
\hline Not at all & 4 & $23.5 \%$ & 0 & $0.0 \%$ & 4 & $16.0 \%$ & 4 & $16.0 \%$ \\
\hline No answer & 4. & $23.5 \%$ & 1 & $12.5 \%$ & 5 & $20.0 \%$ & 3 & $12.0 \%$ \\
\hline Total & 17 & $99.9 \%^{*}$ & 8 & $100.0 \%$ & 25 & $100.0 \%$ & 25 & $100.0 \%$ \\
\hline
\end{tabular}

* Does not equl $100.0 \%$ due to rounding error. 
TABLE LXV

DRINKING IN ORDER TO SHUT OUT THE WORLD

\begin{tabular}{|c|c|c|c|c|c|c|c|c|}
\hline & \multicolumn{2}{|c|}{ Program Males } & \multicolumn{2}{|c|}{ Program Females } & \multicolumn{2}{|c|}{ Sub-Total } & \multicolumn{2}{|c|}{ Non-Program Males } \\
\hline & $\begin{array}{l}\text { Freq. of } \\
\text { response }\end{array}$ & Percent & $\begin{array}{l}\text { req.of } \\
\text { response }\end{array}$ & Percent & $\begin{array}{l}\text { Freq.of } \\
\text { fesponse }\end{array}$ & Percent & $\begin{array}{l}\text { Freq. of } \\
\text { fesponse }\end{array}$ & Percent \\
\hline Usua11y & 6 & $35.3 \%$ & 0 & $0.0 \%$ & 6 & $24.0 \%$ & 4 & $16.0 \%$ \\
\hline Sometimes & 5 & $29.4 \%$ & 3 & $37,5 \%$ & 8 & $32.0 \%$ & 12 & $48.0 \%$ \\
\hline & 5 & $29.4 \%$ & 4 & $50.0 \%$ & 9 & $36.0 \%$ & 8 & $32.0 \%$ \\
\hline No answer & 1 & $5.8 \%$ & 1 & $12.5 \%$ & 2 & $8.0 \%$ & 1 & $4.0 \%$ \\
\hline Total & 17 & $99.9 \%^{*}$ & 8 & $100.0 \%$ & 25 & $100.0 \%$ & 25 & $100.0 \%$ \\
\hline
\end{tabular}

* Does not equal $100.0 \%$ due to rounding error. 
TABLE IXVI

SUICIDE ATTEMPTS WHILE DRINKING

\begin{tabular}{|c|c|c|c|c|c|c|c|c|}
\hline & \multicolumn{2}{|c|}{ Program,Males. } & \multicolumn{2}{|c|}{ Program Females. } & \multicolumn{2}{|c|}{ Sub-Total } & \multicolumn{2}{|c|}{ Non-Program Males } \\
\hline & $\begin{array}{l}\text { Freq. of } \\
\text { response }\end{array}$ & Percent & $\begin{array}{l}\text { Freq.of } \\
\text { response }\end{array}$ & Percent & $\begin{array}{l}\text { Freq. of } \\
\text { cesponse }\end{array}$ & Percent & $\begin{array}{l}\text { Freq. of } \\
\text { fesponse }\end{array}$ & Percent. \\
\hline Never & 12 & $70.6 \%$ & 3 & $37.5 \%$ & 15 & $60.0 \%$ & 15 & $60.0 \%$ \\
\hline Once & 1 & $5.8 \%$ & 3 & $37.5 \%$ & 4 & $16.0 \%$ & 6 & $24.0 \%$ \\
\hline $\begin{array}{l}\text { Several } \\
\text { times }\end{array}$ & 3 & $17.6 \%$ & 1 & $12.5 \%$ & 4 & $16.0 \%$ & 3 & $12.0 \%$ \\
\hline No answer & 1 & $5.8 \%$ & 1 & $12.5 \%$ & 2 & $8.0 \%$ & 1 & $4.0 \%$ \\
\hline Tota1 & 17 & $99.8 \%$ & 8 & $100.0 \%$ & 25 & $100.0 \%$ & 25 & $100.0 \%$ \\
\hline
\end{tabular}

* Does not equal $100.0 \%$ due to rounding error. 
TABLE $\cdot$ LXVII

HARDSHIPS ON FAMILY DUE TO DRINKING

\begin{tabular}{|c|c|c|c|c|c|c|c|c|}
\hline \multirow{2}{*}{$\begin{array}{l}\text { Hardship } \\
\text { on } \\
\text { Family }\end{array}$} & \multicolumn{2}{|c|}{ Program Males } & \multicolumn{2}{|c|}{ Program Females } & \multicolumn{2}{|c|}{ Sub-TotaI } & \multicolumn{2}{|c|}{ Non-Program Males } \\
\hline & $\begin{array}{l}\text { Freq. of } \\
\text { response }\end{array}$ & Percent & $\begin{array}{l}\text { Freq. of } \\
\text { response }\end{array}$ & Percent & $\begin{array}{l}\text { Freq. of } \\
\text { response }\end{array}$ & Percent & $\begin{array}{l}\text { req.of } \\
\text { response }\end{array}$ & Percent \\
\hline Yes & 12 & $70.6 \%$ & 5 & $62.5 \%$ & 17 & $68.0 \%$ & 16 & \\
\hline No & 4 & $23.5 \%$ & 2 & $25.0 \%$ & 6 & $24.0 \%$ & 9 & $36.0 \%$ \\
\hline No answer & 1 & $5.8 \%$ & 1 & $12.5 \%$ & 2 & $8.0 \%$ & 1 & $0.0 \%$ \\
\hline Total & 17. & $99.9 \%^{*}$ & 8 & $100.0 \%$ & 25 & $100.0 \%$ & 25 & $100.0 \%$ \\
\hline
\end{tabular}

* Does not equal $100.0 \%$ due to rounding error. 
TABLE LXVIII

HISTORY OF DRINKING PROBLEMS IN PATIENTS' FAMILIES

\begin{tabular}{|c|c|c|c|c|c|c|c|c|}
\hline \multirow{2}{*}{$\begin{array}{l}\text { History } \\
\text { of } \\
\text { Drinking } \\
\text { Problems }\end{array}$} & \multicolumn{2}{|c|}{ Program Males } & \multicolumn{2}{|c|}{ Program Females } & \multicolumn{2}{|c|}{ Sub-Total } & \multicolumn{2}{|c|}{ Non-Program Males } \\
\hline & $\begin{array}{l}\text { Freq.of } \\
\text { response }\end{array}$ & Percent & $\begin{array}{l}\text { Freq. of } \\
\text { response }\end{array}$ & Percent & $\begin{array}{l}\text { Freq.of } \\
\text { response }\end{array}$ & Percent & $\begin{array}{l}\text { Freq.of } \\
\text { response }\end{array}$ & Percent \\
\hline Yes & 9 & $52.9 \%$ & 5 & $62.5 \%$ & 14 & $56.0 \%$ & 13 & $52.0 \%$ \\
\hline No & 5 & $29.4 \%$ & 2 & $25.0 \%$ & 7 & $28.0 \%$ & 8 & $32.0 \%$ \\
\hline No answer & 3 & $17.6 \%$ & 1 & $12.5 \%$ & 4 & $16.0 \%$ & 4 & $16.0 \%$ \\
\hline Total & 17 & $99.9 \%^{*}$ & 8 & $100.0 \%$ & 25 & $100.0 \%$ & 25 & $100.0 \%$ \\
\hline
\end{tabular}

* Does not equal $100.0 \%$ due to rounding error. 
TABLE LXIX

CHANGE IN ASSOCIATES

\begin{tabular}{|c|c|c|c|c|c|c|c|c|}
\hline \multirow{2}{*}{$\begin{array}{l}\text { Level of } \\
\text { Importance }\end{array}$} & \multicolumn{2}{|c|}{ Program Males } & \multicolumn{2}{|c|}{ Program Females } & \multicolumn{2}{|c|}{ Sub-Total } & \multicolumn{2}{|c|}{ Non-Program Males } \\
\hline & $\begin{array}{l}\text { Freq. of } \\
\text { response }\end{array}$ & Percent & $\begin{array}{l}\text { Freq.of } \\
\text { fesponse }\end{array}$ & Percent & $\begin{array}{l}\text { Freq. of } \\
\text { response }\end{array}$ & Percent & $\begin{array}{l}\text { Freq. of } \\
\text { response }\end{array}$ & Percent \\
\hline Very & 10 & $58.8 \%$ & 3 & $37.5 \%$ & 13 & $52.0 \%$ & 9 & $36.0 \%$ \\
\hline Fairly & 3 & $17.6 \%$ & 1 & $12.5 \%$ & 4 & $16.0 \%$ & 4 & $16.0 \%$ \\
\hline Not at al1 & 1 & $5.8 \%$ & 2 & $25.0 \%$ & 3 & $12.0 \%$ & 6 & $24.0 \%$ \\
\hline No answer & 3 & $17.6 \%$ & 2 & $25.0 \%$ & 5 & $20.0 \%$ & 6 & $24.0 \%$ \\
\hline Total & 17 & $99.8 \%^{*}$ & 8 & $100.0 \%$ & 25 & $100.0 \%$ & 25 & $100.0 \%$ \\
\hline
\end{tabular}

* Does not equal $100.0 \%$ due to rounding error. 
TABLE LXX

\section{GROUP THERAPY}

\begin{tabular}{|c|c|c|c|c|c|c|c|c|}
\hline \multirow{2}{*}{$\begin{array}{l}\text { Level of } \\
\text { Importance }\end{array}$} & \multicolumn{2}{|c|}{ Program Males } & \multicolumn{2}{|c|}{ Program, Females } & \multicolumn{2}{|c|}{ Sub-Total } & \multicolumn{2}{|c|}{ Non-Program Males } \\
\hline & $\begin{array}{l}\text { Freq. of } \\
\text { response }\end{array}$ & Percent & $\begin{array}{l}\text { Freq. of } \\
\text { response }\end{array}$ & Percent & $\begin{array}{l}\text { Freq. of } \\
\text { response }\end{array}$ & Percent & $\begin{array}{l}\text { Freq. of } \\
\text { response }\end{array}$ & Percent \\
\hline Very & 8 & $47.0 \%$ & 6 & $75.0 \%$ & 14 & $56.0 \%$ & 8 & $32.0 \%$ \\
\hline Fairly & 4 & $23.5 \%$ & 1 & $12.5 \%$ & 5 & $20.0 \%$ & 8 & $32.0 \%$ \\
\hline Not at a11 & 2 & $11.7 \%$ & 0 & $0.0 \%$ & 2 & $8.0 \%$ & 4 & $16.0 \%$ \\
\hline No answer & 3. & $17.6 \%$ & 1 & $12.5 \%$ & 4 & $16.0 \%$ & 5 & $20.0 \%$ \\
\hline Total & 17 & $99.8 \%^{*}$ & 8 & $100.0 \%$ & 25 & $100.0 \%$ & 25 & $100.0 \%$ \\
\hline
\end{tabular}

* Does not equal $100.0 \%$ due to rounding error. 
TABLE LXXI

ALCOHOLICS ANONYMOUS

\begin{tabular}{|c|c|c|c|c|c|c|c|c|}
\hline \multirow{2}{*}{$\begin{array}{l}\text { Level of } \\
\text { Importance }\end{array}$} & \multicolumn{2}{|c|}{ Program Males } & \multicolumn{2}{|c|}{ Program Females } & \multicolumn{2}{|c|}{ Sub-Total } & \multicolumn{2}{|c|}{ Non-Program Males } \\
\hline & $\begin{array}{l}\text { Freq. of } \\
\text { response }\end{array}$ & Percent & $\begin{array}{l}\text { rreq. of } \\
\text { response }\end{array}$ & Percent & $\begin{array}{l}\text { Freq.of } \\
\text { eesponse }\end{array}$ & Percent & $\begin{array}{l}\text { Freq.of } \\
\text { cesponse }\end{array}$ & Percent \\
\hline Very & 5 & $29.4 \%$ & 4 & $50.0 \%$ & 9 & $36.0 \%$ & 5 & $20.0 \%$ \\
\hline Fairly & 4 & $23.5 \%$ & 1 & $12.5 \%$ & 5 & $20.0 \%$ & 8 & $32.0 \%$ \\
\hline Not at all & 3 & $17.6 \%$ & 1 & $12.5 \%$ & 4 & $16.0 \%$ & 7 & $28.0 \%$ \\
\hline No answer & 5 & $29.0 \%$ & 2 & $25.0 \%$ & 7 & $28.0 \%$ & 5 & $20.0 \%$ \\
\hline Total & 17 & $99.9 \%^{*}$ & 8 & $100.0 \%$ & 25 & $100.0 \%$ & 25 & $100.0 \%$ \\
\hline
\end{tabular}

* Does not equal $100.0 \%$ due to rounding error. 
TABLE LXXII

INDIVIDUAL THERAPY

\begin{tabular}{|c|c|c|c|c|c|c|c|c|}
\hline \multirow{2}{*}{$\begin{array}{l}\text { Level of } \\
\text { Importance }\end{array}$} & \multicolumn{2}{|c|}{ Program Males } & \multicolumn{2}{|c|}{ Program Females } & \multicolumn{2}{|c|}{ Sub-Total } & \multicolumn{2}{|c|}{ Non-Program Males } \\
\hline & $\begin{array}{l}\text { Freq. of } \\
\text { response }\end{array}$ & Percen & $\begin{array}{l}\text { Freq.of } \\
\text { response }\end{array}$ & Percent & $\begin{array}{l}\text { Freq. of } \\
\text { response }\end{array}$ & Percent & $\begin{array}{l}\text { Freq.of } \\
\text { fesponse }\end{array}$ & Percent \\
\hline Very & 9 & $52.9 \%$ & 4 & $50.0 \%$ & 13 & $52.0 \%$ & 7 & $28.0 \%$ \\
\hline Fairly & 2 & $11.7 \%$ & 2 & $25.0 \%$ & 4 & $16.0 \%$ & 9 & $36.0 \%$ \\
\hline Not at all & 2 & $11.7 \%$ & 0 & $0.0 \%$ & 2 & $8.0 \%$ & 5 & $20.0 \%$ \\
\hline No answer & 4. & $23.5 \%$ & 2 & $25.0 \%$ & 6 & $24.0 \%$ & 4 & $16.0 \%$ \\
\hline TotaI & 17 & $99.8 \% *$ & 8 & $100.0 \%$ & 25 & $100.0 \%$ & 25 & $100.0 \%$ \\
\hline
\end{tabular}

* Does nto equal $100.0 \%$ due to rounding error. 
TABLE LXXIII

EDUCATION ON EFFECTS OF ALCOHOL

\begin{tabular}{|c|c|c|c|c|c|c|c|c|}
\hline \multirow{2}{*}{$\begin{array}{l}\text { Level of } \\
\text { Importance }\end{array}$} & \multicolumn{2}{|c|}{ Program Males } & \multicolumn{2}{|c|}{ Program Females } & \multicolumn{2}{|c|}{ Sub-Total } & \multicolumn{2}{|c|}{ Non-Program Males } \\
\hline & $\begin{array}{l}\text { Freq. of } \\
\text { response }\end{array}$ & Percent & $\begin{array}{l}\text { Freq. of } \\
\text { response }\end{array}$ & Percent & $\begin{array}{l}\text { Freq.of } \\
\text { esponse }\end{array}$ & Percent & $\begin{array}{l}\text { Freq. of } \\
\text { response }\end{array}$ & Percent \\
\hline Very & 6 & $35.3 \%$ & 3 & $37.5 \%$ & 9 & $36.0 \%$ & 6 & $24.0 \%$ \\
\hline Fairly & 4 & $23.5 \%$ & 0 & $0.0 \%$ & 4 & $16.0 \%$ & 7 & $28.0 \%$ \\
\hline Not at a11 & 2 & $11.7 \%$ & 4 & $50.0 \%$ & 6 & $24.0 \%$ & 7 & $28.0 \%$ \\
\hline No answer & 5 . & $29.4 \%$ & 1 & $12.5 \%$ & 6 & $24.0 \%$ & 5 & $20.0 \%$ \\
\hline Total & 17 & $99.9 \%^{*}$ & 8 & $100.0 \%$ & 25 & $100.0 \%$ & 25 & $100.0 \%$ \\
\hline
\end{tabular}

* Does nto equal $100.0 \%$ due to rounding error. 
TABLE LXXIV

COMMUNITY TREATMENT FOR ALCOHOL ABUSE

\begin{tabular}{|c|c|c|c|c|c|c|c|c|}
\hline & \multicolumn{2}{|c|}{ Program Males } & \multicolumn{2}{|c|}{ Program Females } & \multicolumn{2}{|c|}{ Sub-Total } & \multicolumn{2}{|c|}{ Non-Program Males } \\
\hline & $\begin{array}{l}\text { Freq. of } \\
\text { response }\end{array}$ & Percent & $\begin{array}{l}\text { rea.of } \\
\text { response }\end{array}$ & Percent & $\begin{array}{l}\text { Freq.of } \\
\text { response }\end{array}$ & Percent & $\begin{array}{l}\text { Freq.of } \\
\text { tresponse }\end{array}$ & Percent \\
\hline Yes & 4 & $23.5 \%$ & 4 & $50.0 \%$ & 8 & $32.0 \%$ & 7 & $28.0 \%$ \\
\hline No & 11 & $64.7 \%$ & 4 & $50.0 \%$ & 15 & $60.0 \%$ & 18 & $72.0 \%$ \\
\hline No answer & 2 & $11.7 \%$ & 0 & $0.0 \%$ & 2 & $8.0 \%$ & 0 & $0.0 \%$ \\
\hline Total & 17 & $99.9 \%^{*}$ & 8 & $100.0 \%$ & 25 & $100.0 \%$ & 25 & $100.0 \%$ \\
\hline
\end{tabular}

* Does not equal $100.0 \%$ due to rounding error. 
TABLE LXXV

LEVEL OF HEALTH COMPARED WITH A YEAR AGO

\begin{tabular}{|c|c|c|c|c|c|c|c|c|}
\hline \multirow{2}{*}{$\begin{array}{l}\text { Level of } \\
\text { Health }\end{array}$} & \multicolumn{2}{|c|}{ Program Males } & \multicolumn{2}{|c|}{ Program Females } & \multicolumn{2}{|c|}{ Sub-Total } & \multicolumn{2}{|c|}{ Non-Program Males } \\
\hline & $\begin{array}{l}\text { Freq. of } \\
\text { respons }\end{array}$ & Percent & $\begin{array}{l}\text { Freq. of } \\
\text { response }\end{array}$ & Percent & $\begin{array}{l}\text { Freq. of } \\
\text { response }\end{array}$ & Percent & \begin{tabular}{l|} 
Freq.of \\
response
\end{tabular} & Percent \\
\hline Better & 4 & $23.5 \%$ & 1 & $12.5 \%$ & 5 & $20.0 \%$ & 4 & $16.0 \%$ \\
\hline Worse & 6 & $35.3 \%$ & 5 & $62.5 \%$ & 11 & $44.0 \%$ & 10 & $40.0 \%$ \\
\hline $\begin{array}{l}\text { About the } \\
\text { same }\end{array}$ & & $35.3 \%$ & 2 & $25.0 \%$ & 8 & $32.0 \%$ & 11 & $44.0 \%$ \\
\hline INo answer & 1 & $5.8 \%$ & 0 & $0.0 \%$ & 1 & $4.0 \%$ & 0 & $0.0 \%$ \\
\hline Total & 17 & $99.9 \% *$ & 8 & $100.0 \%$ & 25 & $100.0 \%$ & 25 & $100.0 \%$ \\
\hline
\end{tabular}

* Does not equal $100.0 \%$ due to rounding error. 
TABLE LXXVI

USE OF ANTABUSE

\begin{tabular}{|c|c|c|c|c|c|c|c|c|}
\hline & \multicolumn{2}{|c|}{ Program Males } & \multicolumn{2}{|c|}{ Program Females } & \multicolumn{2}{|c|}{ Sub-Tota1 } & \multicolumn{2}{|c|}{ Non-Program Males } \\
\hline & $\begin{array}{l}\text { Freq. of } \\
\text { response }\end{array}$ & Percent & $\begin{array}{l}\text { Freq.of } \\
\text { responsq }\end{array}$ & Percent & $\begin{array}{l}\text { Freq.of } \\
\text { response }\end{array}$ & Percent & $\begin{array}{l}\text { Freq.of } \\
\text { cesponse }\end{array}$ & Percent \\
\hline Yes & 7 & $41.2 \%$ & 0 & $0.0 \%$ & 7 & $28.0 \%$ & 14 & $56.0 \%$ \\
\hline No & 8 & $47.0 \%$ & 8 & $100.0 \%$ & 16 & $64.0 \%$ & 11 & $44.0 \%$ \\
\hline No answer & 2 & $11.7 \%$ & 0 & $0.0 \%$ & 2 & $8.0 \%$ & 0 & $0.0 \%$ \\
\hline Total & 17 & $99.9 \%^{*}$ & 8 & $100.0 \%$ & 25 & $3.00 .0 \%$ & 25 & $100.0 \%$ \\
\hline
\end{tabular}

* Does not equal $100.0 \%$ due to rounding error. 